\title{
Life Cycle Test of the NOXSO Process
}

$\mathrm{DOE} / \mathrm{PC} / 81503--\mathrm{Tl}$

DE92 010606

May 1990

by

W.T. Ma

J.L. Haslbeck

L.G. Neal

NOXSO Corporation

Library Pennsylvania

Work Performed Under U.S. Departrnent of Energy

Cooperative Agreement Contract No. DE-FC22-85PC81503 Dr. James T. Yeh, Project Officer

\section{PGín}




\section{ACKNOWLEDGFMENT}

This work was completed under a Cooperative Research Agreement between the U.S. Department of Energy and NoxSO Corporation. Under this agreement, NoxSO Corporation provided the process technology and the U.S. Department of Eneigy provided the Life cycle Test Unit research facility and operation persounels in carrying out this research. Dr. James $T$. Yeh of the U.S. Department of Energy had the overall responsibility in the research facility design and in the hour-to-hour decisions in this research activity. The facility was built and operated by Gilbert/Commonwealth, Inc, under contract to the Pittsburgh Energy Technology Center. Thanks are also given to Mr. Henry Pennline of PETC for providing many valuable suggestions during the course of the research and to Mr. Frederick Gromicko of Gilbert/ Commonwealth, for the construction and operation of the research facility.

\section{DIGCLAIMER}

\footnotetext{
This report was prepared as an aciount of work sponsored by an agency of the United States Governnient. Neither the United States Government nor any agency thereof, nor any of their emplcyees, makes any warranty, express or implied, or assumes any legal iiability or responsibility for the accuracy, completeness, or usefulness of any information, apparatus, product, or bility for the accuracy, complesed, or represents that its use would not infringe privately owned rights. Reference herein to any specific commercial product, process, or service by trade name, trademark, manufacturer, or otherwise does not necessarily constitute or imply its endorsement, recommendation, or favoring by the United States Government or any agency thereof. The views and opinions of althors expressed herein do not necessarily state or reflect those of the United States Government or any agency thereof.
} 
TABLE OF CONTENTS

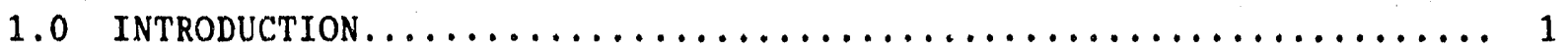

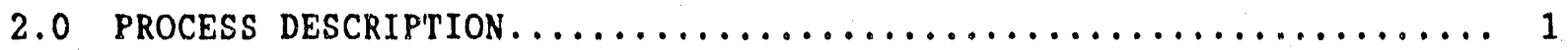

3.0 DESCRIPTION OF THE LIFE CYCLE TEST UNIT (LCTU) $\ldots \ldots \ldots \ldots \ldots \ldots \ldots \ldots$

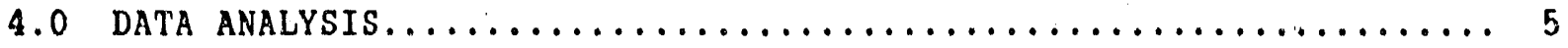

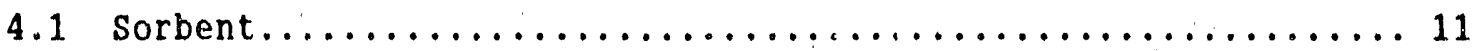

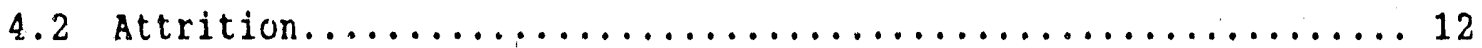

4.2 .1 Sorbent Make-Up......................... 12

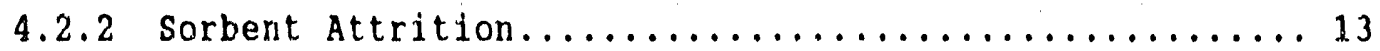

$4.3 \mathrm{No}_{\mathrm{x}}$ Regeneration................................ 19

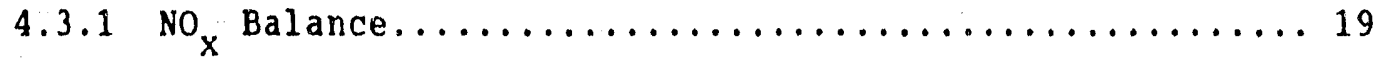

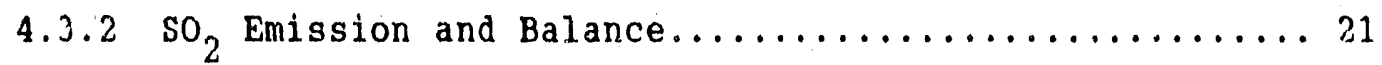

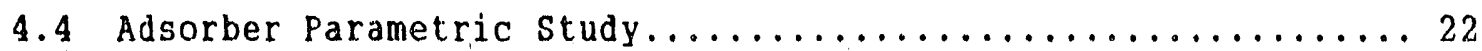

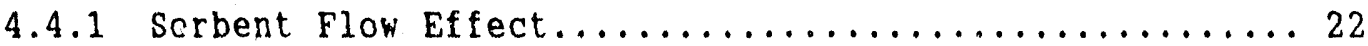

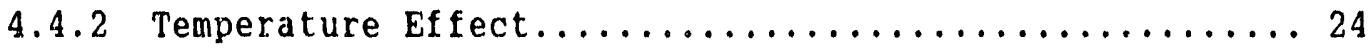

4.4.3 SO2 and Nox Concentration Effect.............. 24

4.4.4 Residence Time Effect..................... 25

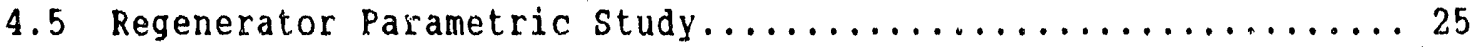

4.5 .1 Hydrogen Versus Natural Gas................. 25

4.5.2 Temperature Effect...................... 26

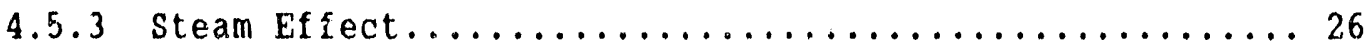

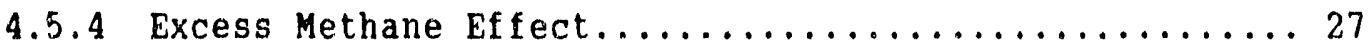

4.5 .5 Nitrogen Effect........................... 28 


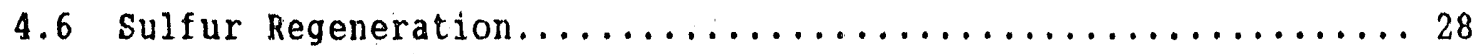

4.6.1 Kinetics of Single-Vessel Regeneration...........28

4.6.2 Sulfur Product Distribution.................43

4.7 puration Test.............................. 4

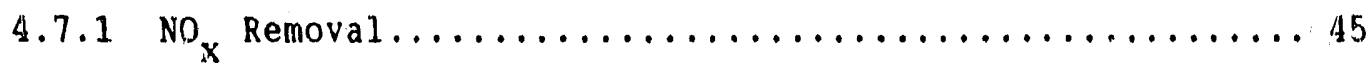

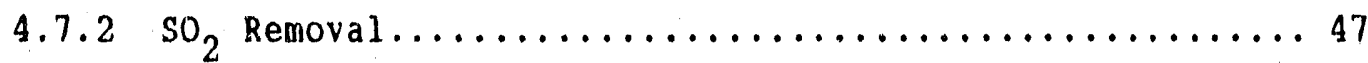

4.7 .3 Sorbent Sodium Content................... 50

4.7.4 Sorbent Surface Area Decay................. 52

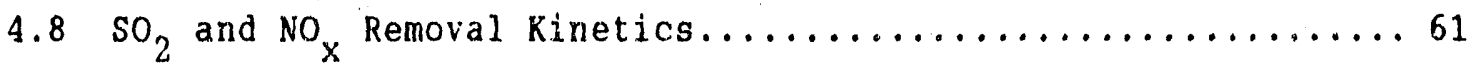

4.9 Effect of sulfur Loading on the $\mathrm{NO}_{x}$ Removal.............67

4.10 Sorbent Chemical Analysis......................... 76

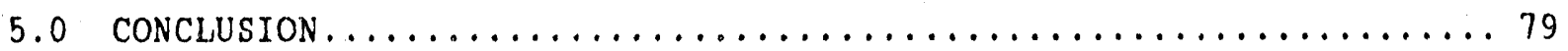

6.0 PRESENTATIONS FROM THE WORK OF THE LIFE CYCLE TEST $\ldots \ldots \ldots \ldots \ldots . \ldots 8$

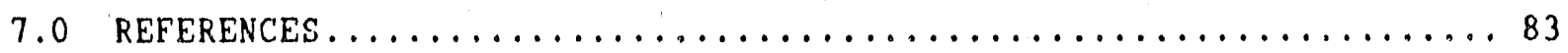




\section{LIST OF FIGURES}

Figure 1. Noxso Process Life Cycle Unit.................... 3

Figure 2. s02 Released From Sorbent Heater.................. 23

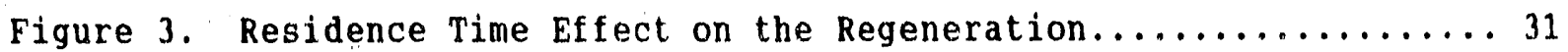

Figure 4. Single Vessel Regeneration - Gas Velocity Effect..........33

Figure 5. Single Vessel Regeneration - CH4 Concentration Effect.......34

Figure 6. Single Vessel Regeneration - Steam Effect...............

Figure 7. Temperature Dependence of Rate Constant.............. 37

Figure 8. Sulfur Content on the Regenerated Sorbent............42

Figure 9. NOx and SO2 Removal of NOXSO-4 and 4 A $\ldots \ldots \ldots \ldots \ldots \ldots$

Figure 10. Sodium Content of Regenerated Noxso-4A............. 48

Figure 11. Surface Area Decay Rate vs. Shrinkable Area........... 55

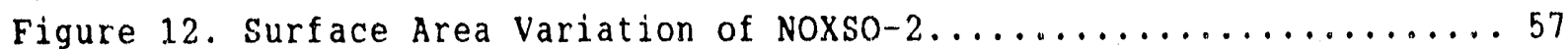

Figure 13. Surface Area Variation of NOXSO-4A................ 58

Figure 14.1/(NOx Removal Rate Constant) .................. 64

Figure 15. 1/(SO2 Removal Rate Constant) .................. 65

Figure 16. Nox Removal Efficiency........................... 68

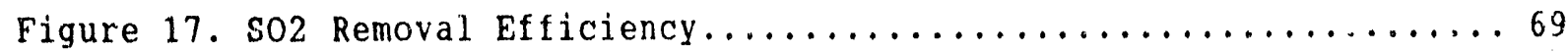

Figure 18. Nox Removed by the spent Sorbent.................. 70

Figure 19. Effect of Sulfur Loading on the Nox Removal............73

Figure 20. Gas/Solid Phase Sulfur Balance.................. 80 


\section{LIST OF TABLES}

Table 1. LCTU Steady-State Performance Data.................. 7-9

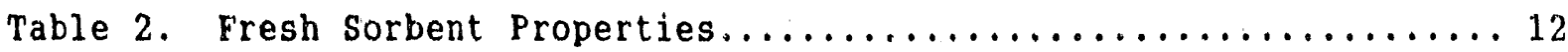

Table 3. Sorbent Make-Up During the LCTU Operation.............. 14

Table 4. Attrition in the

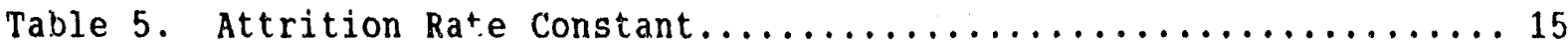

Table 6. Particle Size Distribution of the Entrained Sorbent

From the Fluid-Bed Sorbent Heater................... 17

Table 7. Superficial Gas Velocity in Fluid-Bed Vessels............ 18

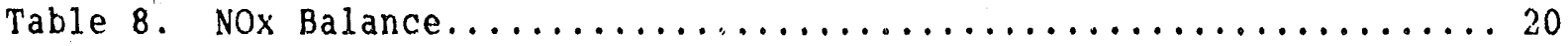

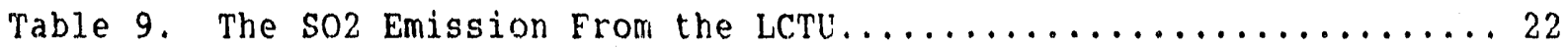

Table 10. Effect of Excess Methane......................... 27

Table 11. Test Conditions for single Vessel Regeneration

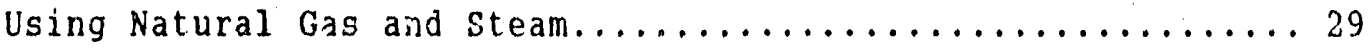

Table 12. Parametric Study Data for Regeneration.............. 40-41

Table 13. Relative Distribution of Reaction

Products on Sorbent Regeneration...................43

Table 14. Sodium Content of Various Particle Sizes for

NOXSO-4A After 163 Regeneration Cycles................ 50

Table 15. Predicted Final Sorbent Surface Area in Different rests..... 56

Table 16. NOXSO-4A Surface Area Change Through a High Temperature Steam Treatment in the Bench-Scale Test........ 59

Table $1 \%$ Porosimetry Analysis of Noxso-4A Sorbent.............. 61

Table 18. NOx Removal and the Sulfur Loading on the spent Sorbent..... 71

Table 19. Chemical Analysis (wt $\%$ ) of Spent Sorbent (PETC)........... 74

Table 20. Cheniral Analysis (wtz) of NOx Regenerated Sorbent (PETC) .... 74

Table 21. Chemical Analysis (wt $\%$ ) of Regenerated Sorbent (PETC).......75

Table 22. Gas/Solid Phase Sulfur Balance.................... 78 


\subsection{INTRODUCTION}

This paper summarizes the data generated by the Noxso Life Cycle Test Unit (LCTU). The paper is divided into the following subsections: description of the NOXSO Process, description of the LCTU, description of the NOXSO sorbents used in the test, $\mathrm{SO}_{2}$ removal efficiency, $\mathrm{NO}_{x}$ removal efficiency, sorbent regeneration, physical and chemical analyses of sorbent used in the test, and attrition data. In addition, information is provided on work undertaken by W.R. Grace \& Co. to assist in the data analysis.

\subsection{PROCESS DESCRIPTION}

The NOXSO process is a dry flue gas treatment system that employs a reusable sorbent. The sorbent consists of sodium carbonate impregnated on a high-surface-area gamma alumina. A fluidized bed of sorbent simultaneously renoves $\mathrm{SO}_{2}$ and $\mathrm{NO}_{x}$ from flue gas at a ten perature of $250^{\circ} \mathrm{F}$. The spent sorbent is regenerated for reuse by treatment at high temperature with a reducing gas. This regeneration reduces sorbed sulfur compounds to $\mathrm{SO}_{2}$ ' $\mathrm{H}_{2} \mathrm{~S}$, and elemental sulfur. The $\mathrm{SO}_{2}$ and $\mathrm{H}_{2} \mathrm{~S}$ are then converted to eiemental sulfur in a claus-type reactor. Tise sulfur produced is a marketable by-product of the process.

Adsorbed nitrogen oxides are decomposed and evolved on heating the sorbent to regeneration temperature. Regeneration of active ${ }^{N O} \mathrm{x}$ sorption sites is, therefore, accomplished simply by heating the sorbent. The concentrated stream of ${ }^{N O} x$ produced on heat-up is returned to the boiler with the combustion air. This may be accomplished without greatly 
increasing the concentration of ${ }^{N O} x$ in boiler flue gas because of the reversibility of ${ }^{\mathrm{NO}} \mathrm{x}$ formation in the boiler.

\subsection{DESCRIPTION OF THE LIFE CYCLE TEST UNIT (LCTU)}

The NOXSO LCTU at PETC is shown schematically in Figure 1. The unit was designed to produce 110 SCFM of coal combustion flue gas by burning about $40 \mathrm{lb} / \mathrm{hr}$ of pulverized coal. The entire test stand measures 8 feet by 16 feet at the base and is 35 feet in height. This does not include the flue gas exhaust $f$ an and stack on the roof of the building. The LCTU consists of three combustors, three fluidized beds, a pneumatic sorbent transport system, a baghouse, a pulverized-coal-handling system, and other components. The system operation and the system components are described below.

In the LCTU, the coal combustor at the lower left corner of Figure 1 generates flue gas that passes through a fluidized-bed adsorber containing NOxSO sorbent prior to entering the baghouse and discharging to the atmosphere. The sorbent is pneumatically transported in 1-pound to 1.25-pound batches from the adsorber to a fluidized-bed sorbent heater, where the sorbent is heated by hot flue gas generated by a natural gas combustor. The sorbent heater continuously feeds heated sorbent (up to $1250^{\circ} \mathrm{F}$ ) to the regenerator, where the used sorbent is regenerated by the regenerating gas. The regenerated sorbent, through a lock hopper, intermittently discharges into the fluidized-bed sorbent cooler. The cooled sorbent $\left(250^{\circ} \mathrm{F}\right)$, through another lock hopper, is fed into the fluidized-bed adsorber to complete the loop. The offgas from the regenerator is passed 


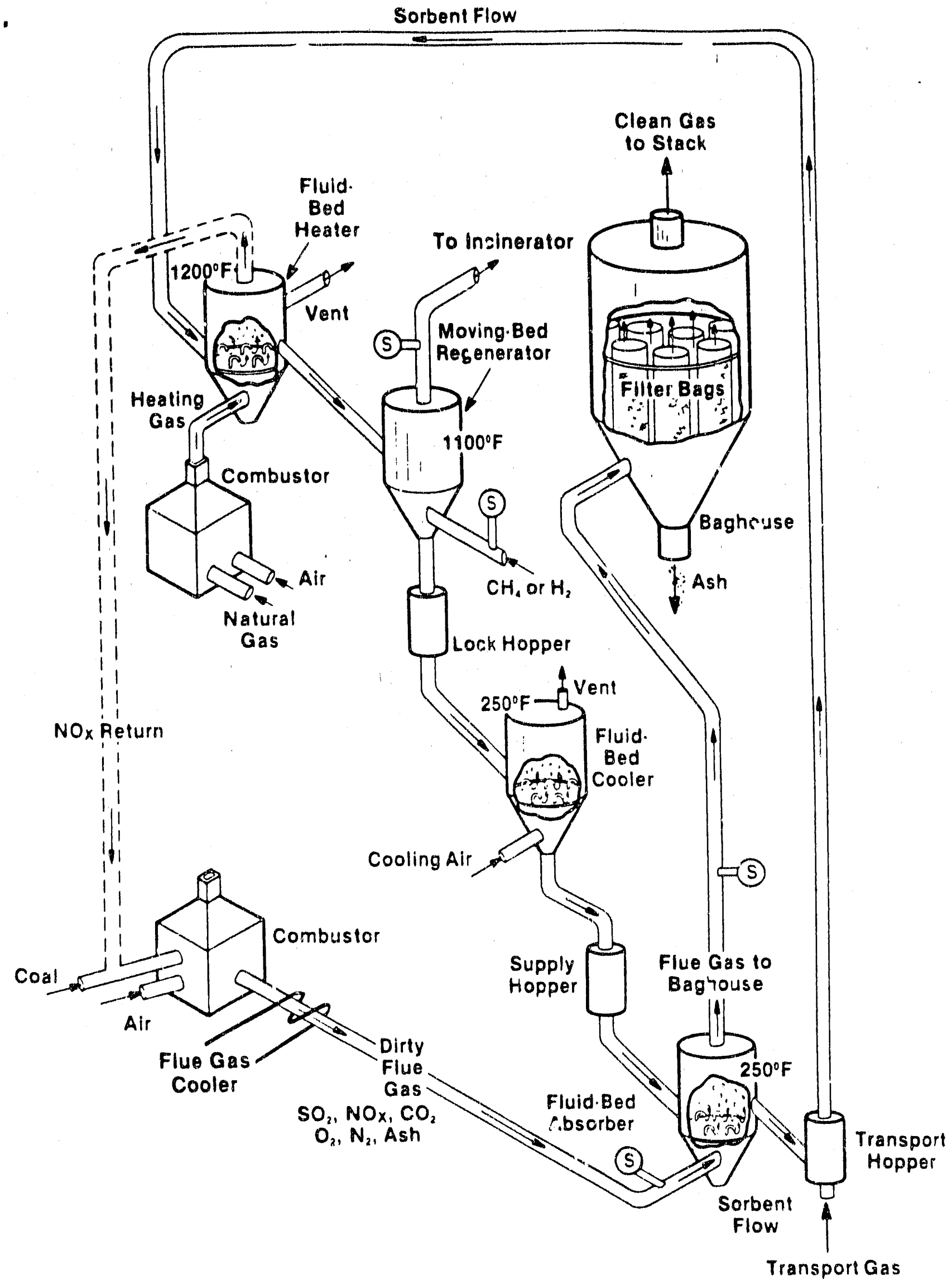

FIGURE 1. NOXSO PROCESS LIFE-CYCLE UNIT. 
through a natural-gas-fired incinerator, hhere any hydrogen sulfide product from the regenerator is oxidized to sulfur dioxide before being discharged.

The combustor is a down-firing gas or pulverized-coal combustor with a screw-ilype coal feeder and a controller. It burns about $40 \mathrm{lb} / \mathrm{hr}$ of pulverized Pittsburgh Seam coal and produces 110 SCFM of flue gas with $20 \%$ excess air. To simulate NOXSO process conditions at the adsorber, the flue gas passes through a train of gas coolers to cool the flue gas to $250^{\circ} \mathrm{F}$ before it enters the adsorber.

The fluidized-bed adsorber has a diameter of 12 inches. The nominal expandled sorbent bed depth is 36 inches, and the superficial velocity of the flue gas is $3 \mathrm{ft} / \mathrm{sec}$. The gas distribution is achieved by a group of 21 J-shaped tubes,

The fluidized-bed sorbent heater heats the used sorbent from the adsorber to slightly above the sorbent regeneration temperature and at the same time thermally regenerates the adsorbed ${ }^{N O} x$ from the sorbent. The sorbent heater has a diameter of 13 inches and has $27 \mathrm{~J}$-tubes. The heated sorbent continuously overflows into the moving-bed regenerator. The heating gas is supplied from a natural gas combustor. The oxygen concentration in the heater offgas is controlled to 36 or less to stay below the explosion limit of hydrogen and methane (regeneration gases) because the heater offgas mav pass to the regenerator through the sorbent transport line. The flue gas from the natural gas combustor is usually diluted with nitrogen to maintain the low oxygen concentration required for safe operation. 
The 12-inch diameter, moving-bed regenerator removes sulfur from the sorbent with hydrogen/steam or natural gas/ateam. The offgas from the regenerator consists of sulfur dioxide, hydrogen sulfide, water vapor, nitrogen, carbon dioxide, elemental sulfur, and unreacted regenerant. The offgas passes through a natural-gas-fired incinerator, where hydrogen sulfide is oxidized to sulfur dioxide. The regenerated sorbent is withdrawn from the bottom of the regenerator into a lock hopper at the designated sorbent flow rate.

The 10-inch diameter, fluidized-bed sorbent cooler uses ambient air to cool the sorbent to the adsorption temperature and transmits the sorbent to the adsorber via a supply hopper. This completes the Noxso adsorption and regeneration process.

Three sorbent transfer hoppers control the transfer of sorbent from one vessel to the other. Each transfei hopper is equipped with a level controller, an inlet and outlet valve, a restrictive-flow orifice, and a nitrogen injection system. During operation, the inlet valve opens and the restrictive orifice located at the inlet to the valve allows the sorbent to flow at a controlled rate into the transfer vessel until the level controller is activated. The level controller consists of an infrared source and a sengor with two glass windows at opposite sides of the vessel.

\subsection{DATA ANALYSIS}

Steady-state operating and performance data from the NoxSO LCTIJ are summarized in Table 1. The LCTU runs continuously, 24 hours a day, 5 days a 
week, with periodic shutdowns for equipment repair and routine maintenance. After each shutdown, the next test period is assigned a new test number. A test number followed by a letter (e.g., 6A or 6B) is used when more than one set of steady-state data was obtained in the same test period. Table 1 lists 14 test periods and $4 L^{i}$ sets of steady-gtate data. Since the parametric test for the regeneration was conducted only during the natural yas regeneration (Test 13 through 15), a detailed list of the gas flowrate for ail the regeneration tests was unnecessary. However, the gas flowrate data for the natural gas regeneration are listed as Table 12 in section 4.6.1.

Any change in operating conditions during a test produces a transition period in which performance dat, are changing with time until a new steady state is achieved. We have arbitrarily defined a steady state as a period in which the performance data do not change with time for a minimum of two sorbent cycles. The length of a sorbent cycle is the total weight of sorbent in the system divided by the sorbent feed rate. The total number of sorbent cycles for eich test is listed in Table 1.

The LCTU data are compared with the results of a 0.75 -Mk test of the Noxso process previously conducted at PETC [1]. However, there are important diricrences in the operation of the two test units that have a significant effect on system perfornance:

- The LCTU is an integrated systen with a continuous flow of sorbent between adsorber and regenerator. In the 0.75-MW test, adsorption and regeneration were batch operations. 
Táble 1. LCTU Steady-State Performance Data

Test

Cumulative Sorbent Cycles

SO2 Removal Efficiency", \&

NOx Removal Efficiency, \&

Inlet $\mathrm{SO}$, $\mathrm{ppm}$

Inlet NOx, ppm

Flue Gas Flow, SCFM

$\triangle \mathrm{P}$ Across Adsorber, $\mathrm{H}_{2} \mathrm{O}$

Adsorber Residence, min

Regeneration Temp. , F

Regenerator Residence, min

Regeneration Gas

Sorbent Feed Rate, $1 \mathrm{~b} / \mathrm{min}$

W't.\% S After Regeneration

Hit. $\%$ S After Adsorption

Wit. $8 \mathrm{Na}$ After Regeneration

Sorbent Surtace Area after Regeneration, $\mathrm{m}^{2} / \mathrm{g}$

Ib SO2/1b Sorbent

Ib N02/1b Sorbent

Test

Cumulative Sorbent Cycles

SO2 Removal Efficiency, *

Nox Removal Efficiency, o

Inlet $\mathrm{SO}_{0}, \mathrm{ppm}$

Inlet NOx, ppm

Flue Gas Flow, SCFM

$\triangle \mathrm{P}$ Across Adsorber, $\mathrm{H}_{2} \mathrm{O}$
Adsorber Temp.

Adsorber Residence, min

Regeneration Temp., ${ }_{F}$

Regenerator Residence, min

Regeneration Gas

Sorbent Feed Rate, Ib/min

Wt. $\delta$ S After Regeneration

Wt. 8 After Adsorption

Wt. $\%$ No After Regeneration

Sorbent Surface Area 2

After Regeneration, $\mathrm{m}^{2} / \mathrm{g}$

1b $502 / 1$ b Sorbent

Ib N02/1b Sorbent

\begin{tabular}{rr}
1 & \multicolumn{2}{c}{2} \\
18.3 & 39.2 \\
35 & 70 \\
15 & 50 \\
1450 & 1420 \\
390 & 380 \\
92 & 101 \\
12 & 14 \\
300 & 265 \\
49 & 57 \\
1050 & 1050 \\
84 & 83
\end{tabular}

$49^{3}$

80

65

1350

400

101

15

265

41

1050

54

$\mathrm{NG} /$ stearl $\mathrm{H} 2 /$ steam $\mathrm{H} 2 /$ steam $\mathrm{H} 2 / \mathrm{steam}$ sequence sequence sequence sequence

$\begin{array}{llll}1.0 & 1.0 & 1.5 & 1.5 \\ 2.6 & 1.8 & \text { ND } & 1.7 \\ 3.2 & 2.5 & \text { ND } & 2.4 \\ 2.7 & 2.2 & \text { ND } & 3.0\end{array}$

1.9

1.8

2.6

3.1

$\mathrm{ND*}$

ND

0.0073

0.0156

ND

0.0006

0.0021

0.0113

0.0020

ND

155

$\begin{array}{lll}0.0126 & 0.0107\end{array}$

0.0018

0.0017
$8 \mathrm{~B}$

72.3

61.8

90

72
2250

500

110

24

270

52
1075

55

H2

1.9

1.3

2.3

ND

ND

0.0182

0.0023

154
0.0198
0.0021

0.0021

1.9

1.0

ND

ND

ND

0.0249

0.0235

0.0101

0.0019

1.9

ND

ND

3.1

33.6

86
72

1450

450

29

270

47

1100

53

H2

$6 \mathrm{~B}$

40.4

90

88

1600

470

101

24

275

52

1100

53

H2

1.9

1.4

2.1

3.1

$7 \mathrm{~A}$

53.7

95

1550

450

105

24

275

52

1100

55

H2

1.9

1.4

2.1

ND

165

ND

0.0119

0.0126

0.0025

0.0022

96

63

1590

320

105

26

285

106

1050

109

H2/

steam

1.0

0.8

2.1

2.9

$8 \mathrm{C}$

74.5

95

60

1600

380

105

17

285

70

1030

109

H2

$8 D$
76.

96

55

1700

420

107

16

290

65

1000

109

H 2 I

steam

1. 0

1.0

0.8

1.8

2.9

0.0

2.1

2.8

150

0.0248

0.0027

0.0024
152

0.0271

0.0028

0.0207
0.0033

*ND $=$ no data 
Table 1. LCTU Steady-State Performance Data (continued)

Test

Cumulative Sorbent Cycles

S02 Removal Efficiency, $\%$

Nox Removal Efficiency, $\%$

Inlet $\mathrm{SO} 2, \mathrm{ppm}$

Inlet NOx, ppm

Flue Gas Flow, SCFM

$\triangle P$ Across Adsorber, $\mathrm{H}_{2} \mathrm{O}$

Adsorber Residence, min

Regeneration Temj., $F$

Regenerator Residence, min

Regeneration Gas

Sorbent Feed Rate, 1b/min

Wt.\& S After Regeneration

wt. $\%$ S After Adsorption

Wt. $8 \mathrm{Na}$ After Regeneration

Sorbent Surface Area 2

After Regenaration, $\mathrm{m}^{2} / \mathrm{g}$

Ib SO2/1b Sorbent

Ib NO2/1b Sorbent

Test

Cumulative Sorbent Cycles

SO2 Removal Efficiency, \&

Nox Removal Efficiency, \&

Inlet $\mathrm{SO}$, $\mathrm{ppm}$

Inlet NOx, ppm

Flue Gas Flon', SCFM

$\triangle P$ Across Adsorbegr, $\mathrm{H}_{2} \mathrm{O}$

Adsorber Temp. , $F$

Adsorber Residence, min

Regeneration Temp., $F$

Regenerator Residence, min

Regeneration Gas

Sorbent Feed Rate, 1b/min

W't.\% S After Regeneration

Wt. $\%$ S After Adsorption

Wt. $\%$ Na Aftor Regeneration

Sorbent Surface Area
After Regeneration, $\mathrm{m}^{2} / \mathrm{g}$

Ib S02/1b Sorbent

lb NO2/1t Sorbent

$\begin{array}{rrr}11 & 12 \mathrm{~A} & 12 \mathrm{~B} \\ 13.2 & 22.2 & 34.7 \\ 80 & 75 & 75 \\ 90 & 70 & 55 \\ 1500 & 1500 & 1500 \\ 550 & 350 & 600 \\ 97 & 115 & 110 \\ 13 & 13 & 13 \\ 255 & 300 & 275 \\ 53 & 53 & 53 \\ 1050 & 1075 & 1060 \\ 110 & 110 & 100 \\ \text { H2/ } & \text { H2/ } & \text { H2/ } \\ \text { steall } & \text { steaml } & \text { steam } \\ 1.0 & 1.0 & 1.0 \\ 0.2 & \text { ND } & 1.0 \\ 2.4 & \text { ND } & \text { ND } \\ 3.07 & 3.08 & \text { ND }\end{array}$

ND

0.0181

0.0054

ND

0.0201

0.0192

0.0041
$12 \mathrm{C}$

40.2

75

44

1500

800

112

13

285

53

1040

97

H2/

steum

1.0

ND

ND

2.95

0.0031

0.0196

0.0044

0.0261

0.0025

53

1050

115

$\mathrm{H} 21$

steam

1.0

1.0

ND

ND
$12 \mathrm{E}$

+ 52.3

E5

47

3000

600

115

13

275

151
261
025

$13 \mathrm{~A}$

82.5

88

55

1624

596

113.2

13

271

53

1134

120

$\mathrm{NG} / \mathrm{N} 2 /$

steami

1.0

0.32

1.25

2.98

141

0.0251

0.0041
$13 \mathrm{~B}$

88

88

47

1447

584

113.7

13

280

53

1120

120

NG /

steam

1.0

0.6

ND

ND

147

0.0225

0.0035
$.13 \mathrm{C}$

95

92

55

1522

589

112.3

12.8

282

35

1120

80

$\mathrm{NG} / \mathrm{N} 2 /$

steam

1.5

0.73

ND

2.86

144

0.0163

0.0027
13D

106

93

80

1523

240

110.2

17

275

46

1120

80

NG/N2/

steam

1.5

0.31

ND

ND

147

0.0162

0.0016
$13 E$

115

89

55

1462

380

108.4

13

270

106

1120

240

$\mathrm{NG} / \mathrm{N} 2 /$

steam

0.5

0.16

ND

2.94

ND

0.0438

0.0051
$13 \mathrm{~F}$

120.1

86

27

153

622

115

13.4

266

1.09

1134

240

$\mathrm{NG} / \mathrm{N} 2 /$

0.5

0.24

ND

ND
$12 \mathrm{~F}$

58.6

81

52

1500

600

112

17

275

69

1055

112

H2/

steam

1.0

ND

ND

ND

151

0.0211

0.0039

ND

0.0190

0.0036

$12 \mathrm{G}$

69.2

74

1500

600

110

10

275

1065

101

$\mathrm{H} 2$ /

steam

1.0

ND

I. 5

ND

D

.036

130

122.2

84

$13 \mathrm{H}$

127.9

89

55

1500

1523

609

711

116.5

12.4

13

272

106

1110

150 
Table 1. LCTU Steady-State Performance Data (continued)

Test

Cumulative Sorbent Cycles SO2 Re Jval Efficiency, \& NOx Removal Efficiency, \&

Inlet SO2, ppm

Inlet NOx, ppm

Flue Gas Flow, SCFM

$\triangle P$ Across Adsorber, $\mathrm{H}_{2} \mathrm{O}$

Adsorber Resjdence, min

Regeneration $3 \mathrm{mp}$., $\mathrm{F}$

Regenerator idence, min

Regeneration Gas

Sorbent Feed Rate, $1 \mathrm{~b} / \mathrm{min}$

Wt. 8 S After Regeneration

W't.\& S After Adsorption

Wt. $\% \mathrm{Na}$ After Regeneration

Sorbent Surface Area

After Regeneration, $\mathrm{m}^{2} / \mathrm{g}$

Ib S02/1b sorbent

lb NO2/lb Sorbent

Test

Cumulative Sorbent Cycles

SO2 Removal Efficiency, *

NOx Removal Efficiency, \&

Inlet $\mathrm{SO} 2, \mathrm{npm}$

Inlet NOx, ppm

Flue Gas Flow, SCFM

$\triangle \mathrm{P}$ Across Adsorber, $\mathrm{H}_{2} \mathrm{O}$

Adsurber Temp. . $F$

Adsorber Residence, min
Regeneration Temp., ${ }_{F}$

Regenerator Residence, min

Regeneration Gas

Sorbent Feed Rate, 1b/min

Wt. 8 S After Regeneration

Wt. \& S After Adsorption

Wt. $\%$ Na After Regeneration

Sorbent Surface Area

After Regeneration, $\mathrm{m}^{2} / \mathrm{g}$

Ib S02/1b Sorbent

Ib N02/lb Sorbent

$\begin{array}{rrrrr}14 \mathrm{~A} & 14 \mathrm{~B} & 14 \mathrm{C} & 14 \mathrm{D} & 14 \mathrm{E} \\ 130.9 & 143 & 147.1 & 153.1 & 160.3 \\ 75 & 67 & 63 & 65 & 70 \\ 46 & 39 & 25 & 48 & 44 \\ 1442 & 1459 & 1447 & 2284 & 1421 \\ 609 & 635 & 583 & 381 & 305 \\ 123.5 & 116.5 & 116.5 & 118 & 116.5 \\ 12.8 & 12.6 & 12.7 & 12.7 & 11.4 \\ 260 & 300 & 350 & 275 & 282 \\ 52 & 51 & 52 & 52 & 47 \\ 1113 & 1109 & 1105 & 1105 & 1105 \\ 128 & 128 & 126 & 128 & 128 \\ \text { NG/N2/ } & \text { NG/N2/ } & \text { NG/N2/ } & \text { NG/N2/ } & \text { NG/N2/ } \\ \text { steam } & \text { steami } & \text { steall } & \text { steam } & \text { steam } \\ 1.0 & 1.0 & 1.0 & 1.0 & 1.0 \\ 0.56 & 0.65 & 0.28 & 0.74 & 0.66 \\ 1.29 & 1.3 & 1.3 & 1.7 & 1.61 \\ \text { ND } & \text { ND } & 2.84 & \text { ND } & 2.79\end{array}$

149

0.0208

0.0039

ND

0.0177

0.00 .12

ND

0.0165

0.0019

ND

0.0272

0.0024

138

0.0180

0.0017

$15 \mathrm{G}$

197.6

70

50
1479

596

117.6

12.6

278

51

1103

129

NG

1.0

0.62

1.71

3.11

$15 \mathrm{~F}$

202.7

67

52

1558

631

113.0

12.4

281

51

1130

128

NG

1.0

0.72

1.42

3.04

143
0.0183

138

0.0189

0.0041
15D

206.8

72

54

1517

571

112.4

12.7

272

52

1117

129

NG /

steam

1.0

0.18

1.45

3.10

137

$15 \mathrm{C}$

20s.1

74

51

1458

576

113.5

12.7

275

52

1136

128

$\mathrm{NG} /$

stean

1.0

0.35

1.16

3.26

0.0191

0.0039
134

0.0190

0.0037
$15 \mathrm{E}$

212.2

74

55
1539

624

118.0

12.6

279

51

1115

129

$\mathrm{NG} /$

steam

1.0

0.13

1.25

3.24

137

0.0209

0.0045

$15 A 1$
172.5
73
55
1.537
603
116.6
12.3
275
50
1125
125
NG/N2/
steani
1.0
0.36
1.19
3.06

$15 B$

$1 \% 2.3$

$15 \mathrm{~A} 2$

186.9

$\begin{array}{rr}25 & 74 \\ 7 & 56 \\ 1542 & 1490\end{array}$

$618 \quad 616$

$113.9 \quad 114.1$

$12.7 \quad 12.9$

$275 \quad 275$

$52 \quad 53$

$1051 \quad 1121$

$128 \quad 127$

$\mathrm{NG} / \mathrm{N}_{2} / \mathrm{NG} / \mathrm{N} 2 /$

steami stearl

$\begin{array}{ll}1.0 & 1.0\end{array}$

2.40

0.38

2.61

3.16

1.07

3,12

141

0.0203

149

137

0.0043

0.0068

0.0195

0.0006

0.0044 
o The LCTU is equipped with a sorbent transport system that was not required in the batch $0.75-\mathrm{MW}$ test. The sorbent transport system has proven to be a significant source of sorbent attrition; therefore, the rate of attrition in the $L C r U$ is higher than the rate in the $0.75-M W$ test.

- Regeneration in the batch mode (0.75-MW test) was continued until there were no sulfur gases detected in the reactor offgas. Regeneration consisted of treatment with a reducing gas followed by treatment with steam. In the LCTU, the sorbent is treated with reducing gas and steam simultaneously in a single reaction vessel, and reaction time is dictated by sorbent residence time, a function of sorbent feed rate and regenerator inventory. For these reasons, regeneration efficiency (found by comparing weight percent sulfur on sorbent samples before and after regeneration) was generally higher in the 0.75 -Mw test.

The LCTU is a smaller system specifically designed to study integrated operation and long-term trends in sorbent activity and attrition rate. The diameter of the LCTU adsorber is 12 inches; the 0.75-MW adsorber was 40 inches square. The small size of the LCTU adsorber has produced slugging problems, a consequence of the high ratio of bed height to bed diameter. Slugging is evidence of poor gas/solid mixing. For this reason, the performance of the LCTU adsorber is not as good as the larger $0.75-\mathrm{MW}$ adsorber. 


\subsection{Sorbent}

Three different sorbents were used in the LCTU. They are NOXSO-2, NOXSO-3, and NOXSO-4. These sorbents were manufactured by the Davison Division of W.R. Grace \& Co. The phystcal properties of all the sorbents used in developing the Noxso process are listed in Table 2, which also contains the test history for each sorbent.

The NOXSO-3 sorbent was the first used in the LCTU. This sorbent was replaced by NOXSO-2 in the beginning of Test 5 because of the high rate attrition measured in Tests 1-4.

The NoxSO-2 sorbent was previously used in a $0.75 \mathrm{MW}$ test of the NoxSO process at PETC [1]. The NOXSO-2 sorbent that was loaded into the LCTU had already been through 16 cycles of regeneration and 17 cycles of adsorption in the $0.75 \mathrm{Mh}$ test. The test of NOXSO-2 continued to Test 10 for about 100 cycles of regeneration. However, Test 10 was not included in the report, since this test was aborted (due to equipment malfunction) before any steady-state data could be obtained.

The NOXSO-4 sorbent was developed to have a largex surface area and a stronger physical strength than NoxsG-2. Two batches of Noxso-4 were manufactured during the LCTU tests. The first batch of NOXSO-4 was used in the LCTU tests beginning with Test 11. The second batch of NoxSO-4, which was designated as NOXSO-4A in Table 2 , was used to make up the attrition loss since Test 13. The test of NOXSO-4 continued for 220 cycles of regeneration. 
Table 2. Fresh Sorbent Properties

\begin{tabular}{|c|c|c|c|c|c|}
\hline Sorbent & NOXSO-1 & NOXSO-2 & NOXsO-3 & NOXSO-4 & NOXSO-4A \\
\hline Sodium, wto & 3.5 & 3.5 & 3.6 & 3.85 & 4.0 \\
\hline Surface Area, m.sq/g & 217 & 181 & 173 & 190 & 234 \\
\hline Bulk Density, $1 \mathrm{~b} / \mathrm{ft}^{3}$ & 42 & 35 & 30 & 38 & 41.8 \\
\hline $\begin{array}{l}\text { Pore volume } \\
\begin{array}{ll}\text { Mac }(>1000 \mathrm{~A}) & \mathrm{cc} / \mathrm{g} \\
\text { Mic } & \mathrm{cc} / \mathrm{g} \\
\text { Total } & , \mathrm{cc} / \mathrm{g}\end{array}\end{array}$ & $\begin{array}{r}0 \\
0.7 \\
0.7\end{array}$ & $\begin{array}{l}0.3 \\
0.6 \\
0.9\end{array}$ & 0.94 & $\begin{array}{l}0.05 \\
0.668 \\
0.718\end{array}$ & $\begin{array}{l}0.016 \\
0.708 \\
0.724\end{array}$ \\
\hline $\begin{array}{l}\text { Average Particle } \\
\text { Diamter, micron }\end{array}$ & 1400 & 1238 & 1366 & 1134 & 1134 \\
\hline Crush Average, ib & 9.9 & 4.7 & 4.2 & 8.5 & 10.1 \\
\hline Air-Jet Attrition, $\$$ & 0.15 & 11.4 & 24.5 & 1.2 & 0.9 \\
\hline Test History & $\begin{array}{l}\text { Paducah, } \\
\text { Kentucky }\end{array}$ & $\begin{array}{r}0.75 \text { Hiw } \\
\& \text { LCTU } \\
5-10\end{array}$ & $\begin{array}{r}\text { LCTU } \\
1.4\end{array}$ & $\begin{array}{r}\text { LCTU } \\
11-14\end{array}$ & $\begin{array}{r}\text { LCTU } \\
13 \cdots 15\end{array}$ \\
\hline
\end{tabular}

\subsection{Attrition}

\subsubsection{Sorbent Make-Up}

Sorbent inventory changes in the throe fluidized beds were determined by pressure drops across the sorbent beds. The sorbent inventory in the regenerator was monitored by a gamma radiation gauge. Sorbent attritjon can be detected continually through the above measurements. When the sorbent: loss was outside a predetermined range, make-up sorbent was added into the cooler during operation. However, the precise sorbent loss during the particular run was determined by emptying all vessels at the end of the test run and weighing the total sorbent inventory in the system, taking into 
account the weight of make up sorbent added and solid samples taken during the test.

\subsubsection{Sorbent Attrition}

Sorbent attrition, during the LCrU tests, was measured through the amount of sorbent makeup, inventory adjustment, and the initial and final sorbent inventory in each vessel. These data are tabulated in Table 3 . The attrition results are expressed in terms of $1 \mathrm{~b} / \mathrm{hr}$, as listed in Table 3 . The attrition rate was calculated as follows: attrition = (initial sorbent inventory + total amount of makeup sorbent - total amount of sorbent removed as a sample - final sorbent inventory)/operating time. Since the attrition rate varies widely even for the same kind of sorbent between different tests, an averaged attrition rate will be used in the following discussion. The laboratory-measured crush strength and the air-jet attrition together with the averaged attrition rates are tabulated in Table 4. Clearly, the NOXSO-3 sorbent exhibits the most attrition. Although NOXSO-2 has less crush strength and higher air-jet attrition than NOXSO-4 and NOXSO-4A, the LCTU test results show that NOXSO-2 has the least sorbent attrition. This contradiction may be explained by considering the attrition in the bed as [2] :

$$
\frac{d W}{d t}=k_{0} A \rho_{p}
$$

where $W$ is the weight loss due to attrition

$t$ is the tine

$k_{0}$ is the attrition rate constant 
A is the exterior surface area of the particle

$\rho_{\mathrm{p}}$ is the particle density.

Table 3. Sorbent Make-up During the LCTU Operation

\begin{tabular}{|c|c|c|c|c|c|}
\hline $\begin{array}{l}\text { Test } \\
\text { No. }\end{array}$ & $\begin{array}{r}\text { NOXSO } \\
\text { Sorbent ID } \\
\end{array}$ & $\begin{array}{c}\text { Sorbent } \\
\text { Initial, } 1 \mathrm{~b}\end{array}$ & $\begin{array}{l}\text { Inventory } \\
\text { Final, Ib }\end{array}$ & $\begin{array}{c}\text { Make-up } \\
\text { Sorbent, 1b }\end{array}$ & $\begin{array}{c}\text { Sampled } \\
\text { Sorbent, Ib }\end{array}$ \\
\hline $\begin{array}{l}1 \\
2 \\
3 \\
4\end{array}$ & $\begin{array}{l}3 \\
3 \\
3 \\
3\end{array}$ & $\begin{array}{l}190 \\
176 \\
189.6 \\
189.3\end{array}$ & $\begin{array}{l}176 \\
182 \\
191.3 \\
213.6\end{array}$ & $\begin{array}{r}0 \\
50 \\
30 \\
50\end{array}$ & $\begin{array}{l}0 \\
2 \\
2 \\
2\end{array}$ \\
\hline $\begin{array}{r}5 \\
6 \\
7 \\
8 \\
9 \\
10\end{array}$ & $\begin{array}{l}2 \\
2 \\
2 \\
2 \\
2 \\
2\end{array}$ & $\begin{array}{l}248 \\
244.1 \\
272.6 \\
280 \\
262.2 \\
215.6\end{array}$ & $\begin{array}{l}247.1 \\
275.6 \\
301.4 \\
268.2 \\
218.6 \\
265.2\end{array}$ & $\begin{array}{r}30 \\
50 \\
50 \\
20 \\
0 \\
60\end{array}$ & $\begin{array}{l}3 \\
3 \\
3 \\
6 \\
3 \\
4\end{array}$ \\
\hline $\begin{array}{l}11 \\
12 \\
13 \\
14 \\
15\end{array}$ & $\begin{array}{c}4 \\
4 \\
4 / 4 \mathrm{~A} \\
4 / 4 \mathrm{~A} \\
4 \mathrm{~A}\end{array}$ & $\begin{array}{l}240 \\
258.3 \\
240.2 \\
250.2 \\
267\end{array}$ & $\begin{array}{l}258.3 \\
197.9 \\
258.4 \\
241 \\
269\end{array}$ & $\begin{array}{l}40.28 \\
160 \\
173 \\
80 \\
190\end{array}$ & $\begin{array}{l}1.3 \\
6.8 \\
4.8 \\
4.8 \\
7.1\end{array}$ \\
\hline
\end{tabular}

Table 1. Sorbent Make-up During the LCTU Operation (continued)

Test Sorbent Cycle operate Attrition Mean Attrition

No.l Circulate, cycle rime, $\mathrm{hr}$ Time, hr Rate, $1 \mathrm{~b} / \mathrm{hr}$ Rate, $1 \mathrm{~b} / \mathrm{hr}$

$\begin{array}{rrrrrr}1 & 18.3 & 3.1 & 56.73 & 0.25 & \\ 2 & 20.9 & 3.0 & 62.70 & 0.67 & \\ 3 & 10.3 & 2.1 & 21.63 & 1.22 & \\ 4 & 12.8 & 2.2 & 28.16 & 0.84 & 0.74 \\ 5 & 26.7 & 2.2 & 58.74 & 0.47 & \\ 6 & 13.7 & 2.3 & 31.51 & 0.49 & \\ 7 & 24.4 & 2.6 & 63.44 & 0.29 & \\ 8 & 11.9 & 4.6 & 54.74 & 0.47 & \\ 9 & 16.2 & 4.4 & 64.80 & 0.63 & \\ 10 & 9.5 & 4.4 & 38.00 & 0.17 & 0.42 \\ & & & & & \\ 11 & 13.2 & 4.4 & 52.80 & 0.39 & 0.63 \\ 12 & 64.0 & 3.8 & 243.20 & 0.88 & \\ 13 & 50.7 & 4.2 & 212.94 & 0.70 & 0.67 \\ 14 & 32.4 & 4.1 & 132.84 & 0.64 & 0.59 \\ 15 & 68.5 & 4.5 & 308.25 & 0.59 & \end{array}$


Table 4. Attrition in the LCTU Test

\begin{tabular}{|c|c|c|c|}
\hline Sorbent & $\begin{array}{l}\text { Attrition } \\
1 \mathrm{~b} / \mathrm{hr} \\
\end{array}$ & $\begin{array}{c}\text { Crush Strength } \\
1 \mathrm{~b}\end{array}$ & $\begin{array}{c}\text { Air-Jet } \\
\frac{8}{2} \\
\end{array}$ \\
\hline & & used (Fresh) & used (Fresh) \\
\hline NOXSO-1 & -- & $=(9.9)$ & $-(0.15)$ \\
\hline NOXSO-2 & 0.42 & $(4.7)$ & $0.31 \quad(11.4)$ \\
\hline NOXSO-3 & 0.74 & $(4.2)$ & $-\quad(24.5)$ \\
\hline NOXSO-4 & 0.63 & $(8.5)$ & $--(1.2)$ \\
\hline NOXSO-4A'4 & 0.67 & $(10.1)$ & $0.11(0.9)$ \\
\hline NOXSO-4A & 0.59 & $(--)$ & $--(--)$ \\
\hline
\end{tabular}

Substituting the attrition, $1 \mathrm{~b} / \mathrm{hr}$, and the sorbent density into Equation 1 cives the value of $K_{D}$ for the sorbents tested. The calculations and results are shown in Table 5 .

Table 5. Attrition Rate Constant

\begin{tabular}{|c|c|c|c|}
\hline Sorbent & $\begin{array}{c}\text { Attrition } \\
\mathrm{lb} / \mathrm{hr} \\
\end{array}$ & $\begin{array}{r}\text { Density } \\
1 \mathrm{~b} / \mathrm{It}^{3} \\
\end{array}$ & $\begin{array}{l}K_{0}{ }^{A} \\
\mathrm{fr}^{3} / \mathrm{hr} \\
\end{array}$ \\
\hline NOXSO-3 & 0.74 & 30 & 0.024 \\
\hline NOXSO-2 & 0.42 & 35 & 0.012 \\
\hline NOXSO-4 & 0.63 & 38 & 0.017 \\
\hline NOXSO-4/4A & 0.67 & $40 *$ & 0.017 \\
\hline NOXSO-4A & 0.59 & 41.8 & 0.014 \\
\hline
\end{tabular}

* A mean density of NOXSO-4 and NOXSO-4A

The value of $\mathrm{K}_{0} \mathrm{~A}$ shows that NOXSO-3 has the most attrition and NOXSO-4A has the least; which agrees with the laboratory measurements obtained from the crush strength and air-jet attrition tests, even though $K_{0} A$ is in terms of sorbent volume while air-jet is in terms of sorbent weight. The results of the air-jet test on the fresh NOXSO-3 and $4 / 4 \mathrm{~A}$ sorbents show a distinct difference which agrees with the LCTU attrition results. The results of the air-jet test on the used NOXSO-2 and NOXSO-4/4A show a small difference, but 
their crush strengths are quite different. Recalling the $K_{0}{ }^{A}$ value obtained from the LCTU test for NOXSO-2, NOXSO-3, and NOXSO-4A, we infer that there is a minimum sorbent crush strength below which the attrition will be significant.

Tests show that the sorbent transport system caused a significant amount of the attrition occurring in the LCTU (see below). We therefore suggest that the a rition caused by the sorbent transport system was severe enough to grind up sorbent regardless of differences in air-jet and crush strength tests. The increase of crush strength from NOxSO-3 to NOXSO-2 reduced the attrition within the fluid-bed vessel, but a further increase of crush strength from NOXSO-2 to NOXSO-4A has not enough to overcome the attrition caused by the sorbent transport system. These results showed that all sorbents except NOXSO-3 have a similar attrition rate.

The LCTU sorbent transport system was tested separately to determine Its contribution to the overall rate of attrition. As previously mentioned in the description of the test unit, the LCrU transport system consists of three sorbent hoppers with ball valves at top and bottom that can grind up sorbent on opening and closing. We tested one of these hoppers, the transport hopper. The results were as follows [3]:

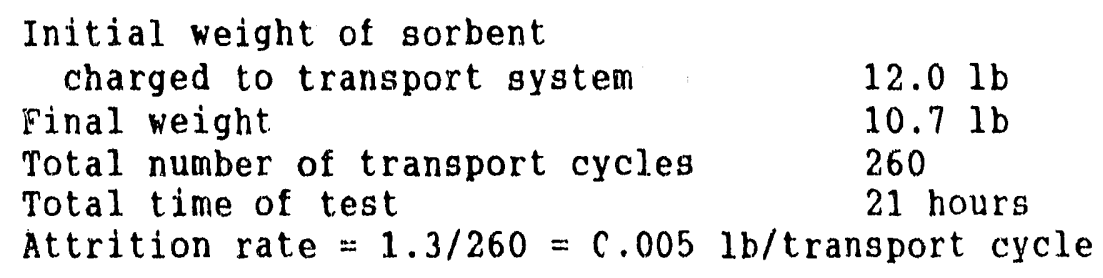


The contribution of the sorbent transport system to the overall rate of attrition measured in the LCTU is found by multiplying the number of transport cycles per test (obtained from the data log) by the transport attrition rate shown above and comparing this loss with the total loss measured in each test. The calculation shows that the transport system accounts for $50 \%$ to $80 \%$ of the attrition occurring in tive LCTU.

The sorbent entrainment from the fluid-bed vessels also increased the overall rate of attrition. There were three fluid-bed vessels in the test unit, namely: adsorber, sorbent heater, and sorbent cooler. The vent from the adsorber entered a baghouse in which the flyash mixed with the attrited sorbent. It was difficult to separate them to determine the relative amount of each. The sorbent cooler vent went directly to the atmosphere. The only place to collect the entrained sorbent was from the bottom of a knockout drum installed on the vent of the sorbent heater. The particle size distribution of an entrained sorbent sample after LCTU Test 15 is listed in Table 6 . About $5 \%$ of the sample is the full size sorbent (>850 microns).

Table 6. Particle Size Distribution of the Entrained Sorbent from the Fluid-Bed Sorbent Heater

\begin{tabular}{|c|c|c|c|}
\hline $\begin{array}{r}\mathrm{Pa} \\
\text { mesh } \\
\end{array}$ & $\begin{array}{l}\text { Size } \\
\text { micron } \\
\end{array}$ & wts & $\begin{array}{c}\text { Cumulative } \\
\text { wtq }\end{array}$ \\
\hline $\begin{array}{l}+16 \\
-16+20 \\
-20+30 \\
-30+40 \\
-40+60 \\
-60+100 \\
-100+200 \\
-200\end{array}$ & $\begin{aligned} d & >1180 \\
1180 & >d>850 \\
850 & >d>600 \\
600 & >d>425 \\
425>d & >250 \\
250 & >d>150 \\
150>d & >75 \\
75>d & \end{aligned}$ & $\begin{array}{r}3.32 \\
1.95 \\
1.17 \\
5.27 \\
34.85 \\
21.56 \\
16.28 \\
15.28\end{array}$ & $\begin{array}{r}3.32 \\
5.27 \\
6.44 \\
11.71 \\
46.56 \\
68.12 \\
84.40 \\
99.98\end{array}$ \\
\hline
\end{tabular}


The contribution of other fluid-bed vessels to the sorbent entrainment was approximated from the gas superficial velocities in each vessel. Table 7 summarizes the operation condition of LCTU Tests 14 and 15 . It is noted that the operating superficial gas velocities in the fluid-bed vessels are less than the calculated terminal velocities listea in Table 7 . However, the attrition broke the sorbent beads into smaller ones, which increased the density of the gas such that the full size beads would be carried out of the fluid-bed vessel even at lower gas velorities.

Table 7. Superficial Gas Velocity in Fluid-Bed Vessels

\begin{tabular}{|c|c|c|c|c|c|c|}
\hline \multirow[b]{2}{*}{$\begin{array}{l}\text { Test } \\
\text { No.\# }\end{array}$} & \multicolumn{3}{|c|}{ Vessel Temperature, ${ }^{\circ} \mathrm{F}$} & \multicolumn{3}{|c|}{ Superficlal Gas Velocity, $\mathrm{ft} / \mathrm{se}$} \\
\hline & Adsorber & $\begin{array}{l}\text { Sorbent } \\
\text { Heater }\end{array}$ & $\begin{array}{l}\text { Sorbent } \\
\text { Cooler }\end{array}$ & Idsorber & $\begin{array}{l}\text { Sorbent } \\
\text { Heater }\end{array}$ & $\begin{array}{l}\text { Sorbent } \\
\text { Cooler }\end{array}$ \\
\hline $\begin{array}{l}14 \mathrm{~A} \\
14 \mathrm{~B} \\
14 \mathrm{C} \\
14 \mathrm{D} \\
14 \mathrm{E}\end{array}$ & $\begin{array}{l}260 \\
300 \\
350 \\
275 \\
282\end{array}$ & $\begin{array}{l}1219 \\
1218 \\
1229 \\
1244 \\
1239\end{array}$ & $\begin{array}{l}160 \\
170 \\
153 \\
158 \\
165\end{array}$ & $\begin{array}{l}3.63 \\
3.62 \\
3.85 \\
3.54 \\
3.53\end{array}$ & $\begin{array}{l}6.18 \\
6.25 \\
6.45 \\
6.52 \\
6.53\end{array}$ & $\begin{array}{l}6.79 \\
6.11 \\
6.99 \\
6.48 \\
6.59\end{array}$ \\
\hline $\begin{array}{l}15 \mathrm{Al} \\
15 \mathrm{~B} \\
15 \mathrm{~A} 2 \\
15 \mathrm{G} \\
15 \mathrm{~F} \\
15 \mathrm{D} \\
15 \mathrm{C} \\
15 \mathrm{E} \\
15 \mathrm{H} \\
\text { Avg. }\end{array}$ & $\begin{array}{l}275 \\
275 \\
276 \\
278 \\
281 \\
272 \\
275 \\
279 \\
279 \\
283\end{array}$ & $\begin{array}{l}1208 \\
1165 \\
1164 \\
1222 \\
1158 \\
1262 \\
1147 \\
1173 \\
1242 \\
1206\end{array}$ & $\begin{array}{l}160 \\
156 \\
155 \\
151 \\
166 \\
148 \\
142 \\
156 \\
150 \\
156\end{array}$ & $\begin{array}{l}3.48 \\
3.42 \\
3.43 \\
3.54 \\
3.42 \\
3.36 \\
3.41 \\
3.56 \\
3.39 \\
3.51\end{array}$ & $\begin{array}{l}6.38 \\
5.78 \\
5.86 \\
6.28 \\
5.72 \\
6.35 \\
5.11 \\
5.17 \\
6.25 \\
6.06\end{array}$ & $\begin{array}{l}5.72 \\
5.50 \\
6.76 \\
6.67 \\
6.73 \\
6.43 \\
6.44 \\
6.37 \\
6.38 \\
6.43\end{array}$ \\
\hline mul & Fluidizatio & Velocit & & 1.2 & 0.8 & \pm .2 \\
\hline nina & Veloc $\alpha t y^{*}$ & & & 16.9 & 18.3 & 16.3 \\
\hline
\end{tabular}

* Calculated value based on the average particle diameter of NOXSO-4 and the corresponding gas composition and temperature in each fluid bed vessel. 
Clearly, the gas superficial velocity in the sorbent cooler was close to that in the surbent heater. This implies that the entrainment observed in the sorbent heater also occurred in the sorbent cooler. Since 58 of the sorbent sample, collected in the offgas line from sorbent heater, is full stze sorbent, the entrainment of unattrited sorbent contributes about 58 of the overall attrition.

Given the magnitude of the contribution of the sorbent transport system and the sorbent entrainment to the overall rate cf attrition measured in the LCTU, we conclude that the LCTU is not a proper device to determine the sorbent attrition.

\subsection{No $x$ Regeneration}

\subsection{1 $\mathrm{NO}_{\mathrm{X}}$ Balance}

The adsorbed ${ }^{N O} x$ was decomposed and evolved on heating the sorbent to regeneration temperature in the sorbent heater. During the heating process, some adsorbed $\mathrm{SO}_{2}$ also evolved. The amount of $\mathrm{SO}_{2}$ released will be discussed in the next section. The extent of $\mathrm{NO}_{x}$ regeneration was confirmed by checking the material balance on $\mathrm{NO}_{x}$ around the adsorber and the sorbent heater.

In the LCTU system, the sorbent from the adsorber was transported into the sorbent heater intermittently, and as a result, the ${ }^{N O} x$ concentration at the exit of the sorbent heater exhibited periodic peaks similar 
to a rectified sine wave. The frequency of the peak coincided with the periodic sorbent transport in the LCTU. Material balance was made by compariug the moles of $\mathrm{NO}_{x}$ adsorbed in the adsorber per ait time to the moles of $\mathrm{NO}_{x}$ exiting the sorbent heater during the same period of time. Moles of ${ }^{N O} x$ removed from the adsorber was calculated from the tilue gas fluw rate, the inlet "NO $x$ concentration, and the ${ }^{N}{ }_{x}$ removal efficiency. Moles of ${ }^{N O} x$ reieased from the sorbent heater was calculated by integration of the area under the sine wave-like curves. The No removed from the adsorber in mol/min and the No, released irom the sorbent heater also in mol/min are given in Table 8. The ratios of moles of ${ }^{N o} x$ released to the moles of $\mathrm{NO}_{x}$ adsorbed for Tests $15 \mathrm{Al}$ through $15 \mathrm{H}$ are calculated.

Clearly, the ${ }^{N} x$ material balance indicates that the ${ }^{N O} x$ regeneration is completed by just heating up the sorbent. It should be pointed out that heating does not completely restore the sorbent's $\mathrm{NO}_{\mathrm{x}}$ removal ability. The sulfur regeneration is needed to restore the No removal abiiity, because the residual sulfur effects the ${ }^{\mathrm{NO}} \mathrm{x}$ adsorption. This will be discussed in section 4.7 .

Table 8. NOx Falance

$\begin{array}{lccc}\text { Test No. } & \begin{array}{c}\text { Nox Adsorbed } \\ \text { mol } / \mathrm{min} \times 10^{6}\end{array} & \begin{array}{c}\text { Nox Released } \\ \text { mol/min } \times 10^{6}\end{array} & \begin{array}{c}\text { Ratio of NOx Released } \\ \text { to NOx Adsorber }\end{array} \\ \text { 15A1 } & 93.9 & 84.8 & 0.903 \\ 15 \mathrm{~B} & 11.9 & 10.8 & 0.907 \\ 15 \mathrm{~A} 2 & 95.5 & 91.3 & 0.956 \\ 15 \mathrm{G} & 85.0 & 80.0 & 0.941 \\ 15 \mathrm{~F} & 90.0 & 73.0 & 0.811 \\ 15 \mathrm{D} & 84.2 & 83.4 & 0.991 \\ 15 \mathrm{C} & 81.0 & 66.3 & 0.818 \\ 15 \mathrm{E} & 98.4 & 83.8 & 0.852 \\ 15 \mathrm{H} & 82.3 & 63.4 & 0.759\end{array}$


The amount of $\mathrm{NO}_{2}$ produced during the $\mathrm{NO}_{x}$ regeneration was also investigated in Test 15. A Thermo Electron Model 10 chemiluminent ${ }^{N O / N O}{ }_{x}$ analyzer was installed on the offgas stream from the sorbent heater. The analyzer equipped a switch to select either ${ }^{N}{ }_{x}$ or NO reading one at a time. The $\mathrm{NO}_{2}$ concentration was calculated by subtracting the No reading from the ${ }^{\mathrm{NO}} \mathrm{x}$ reading. Several attempts were made to determine the $\mathrm{NO}_{2}$ concentration during Test 15, but all of them failed. No significant difference between the NO and ${ }^{N O}{ }_{x}$ readings was found. The failure to determine the $\mathrm{NO}_{2}$ concentration in the offgas from sorbent heater was mainly due to the following reasons: 1) The hot gas from the airheater was inerted with nitrogen before sending it to the sorbent heater. The use of nitrogen diluted the $\mathrm{NO}_{2}$ concentration. 2) The $\mathrm{NO}_{\mathrm{NO}} \mathrm{x}$ concentration of offgas oscillated like a sine wave. It was not possible to obtain a reliable calculation by switching the analyzer back and forth between the NO and $\mathrm{NO}_{x}$ monitoring modes, and tìen subtracting one reading from another.

\subsection{2 $\mathrm{SO}_{2}$ Emission and Balance}

The amount of $\mathrm{SO}_{2}$ released from the sorbent heater during the ${ }^{\mathrm{N} O} \mathrm{x}$ regeneration was monitored in LCTU Test 15 . The results are listed in Table 9 along with the $\mathrm{SO}_{2}$ emitied from the incinerator.

Since the sorbent heater and the incinerator are the only places where $\mathrm{SO}_{2}$ leaves the test unit, the sum of $\mathrm{SO}_{2}$ emitted from these vessels (coiumn 4 in Table 9) stands for the sulfur balance for the entire test unit; even though some elemental sulfur from the regeneration deposited on 
the pipe surface and never made its way to the incinerator. However. except for the data of Test $15 \mathrm{H}$, the sulfur balance ranges from $75 \%$ to 1108 of the $\mathrm{SO}_{2}$ removed in the adsorber. While it is believed that the amount of $\mathrm{SO}_{2}$ released in the sorbent heater is related to the amount of $\mathrm{SO}_{2}$ adsorbed in the adsorber, current data is insufficient to prove this. A plot of $\mathrm{SO}_{2}$ removed in the adsorber against $\mathrm{SO}_{2}$ released in the sorbent heater is shown in Figure 2. $\mathrm{sO}_{2}$ emissions as in the sorbent heater average about 68 of the adsorbed $\mathrm{SO}_{2}$.

Table 9. The SO2 Enission from the LCTU

\begin{tabular}{|c|c|c|c|}
\hline $\begin{array}{l}\text { Test } \\
\text { No.\# }\end{array}$ & $\begin{array}{c}\text { Sorbent Heater } \\
\% \\
\end{array}$ & $\begin{array}{c}\text { Incinerator } \\
8\end{array}$ & $\begin{array}{l}\text { Total SO2 Emission as of } \\
\text { of SO2 Removed in Adsorber } \\
\end{array}$ \\
\hline $\begin{array}{l}15 \mathrm{~A} 1 \\
15 \mathrm{~B} \\
15 \mathrm{~A} 2 \\
15 \mathrm{G} \\
15 \mathrm{~F} \\
15 \mathrm{D} \\
15 \mathrm{C} \\
15 \mathrm{E} \\
15 \mathrm{H}\end{array}$ & $\begin{array}{l}3.3 \\
0 \\
4.1 \\
5.2 \\
6.8 \\
3.4 \\
2.2 \\
6.6 \\
8.6\end{array}$ & $\begin{array}{r}103.5 \\
74.5 \\
105.9 \\
69.9 \\
92.4 \\
105.8 \\
97.2 \\
86.1 \\
131.5\end{array}$ & $\begin{array}{r}106.8 \\
74.5 \\
110.0 \\
75.1 \\
99.2 \\
109.2 \\
99.4 \\
92.7 \\
140.1\end{array}$ \\
\hline
\end{tabular}

\subsection{Adsorber Parametric Study}

\subsubsection{Sorbent Flow Ef fect}

The effects of sorbent circulation rate in the system on $\mathrm{SO}_{2}$ and ${ }^{\mathrm{NO}} \mathrm{x}$ removal were studied in Test $13 \mathrm{~A}$ through Test $13 \mathrm{H}$. The results are tabulated in Table 1. Tests 13C, 13B, and $13 \mathrm{~F}$ can be compared at similar test conditions, namely: $1500 \mathrm{ppm}$ inlet $\mathrm{sO}_{2}, 600 \mathrm{ppm} \mathrm{NO}{ }_{X}, 275^{\circ} \mathrm{F}$ adsorber temperature, $1125^{\circ} \mathrm{F}$ regeneration temperature, 13 inches water pressure drop 


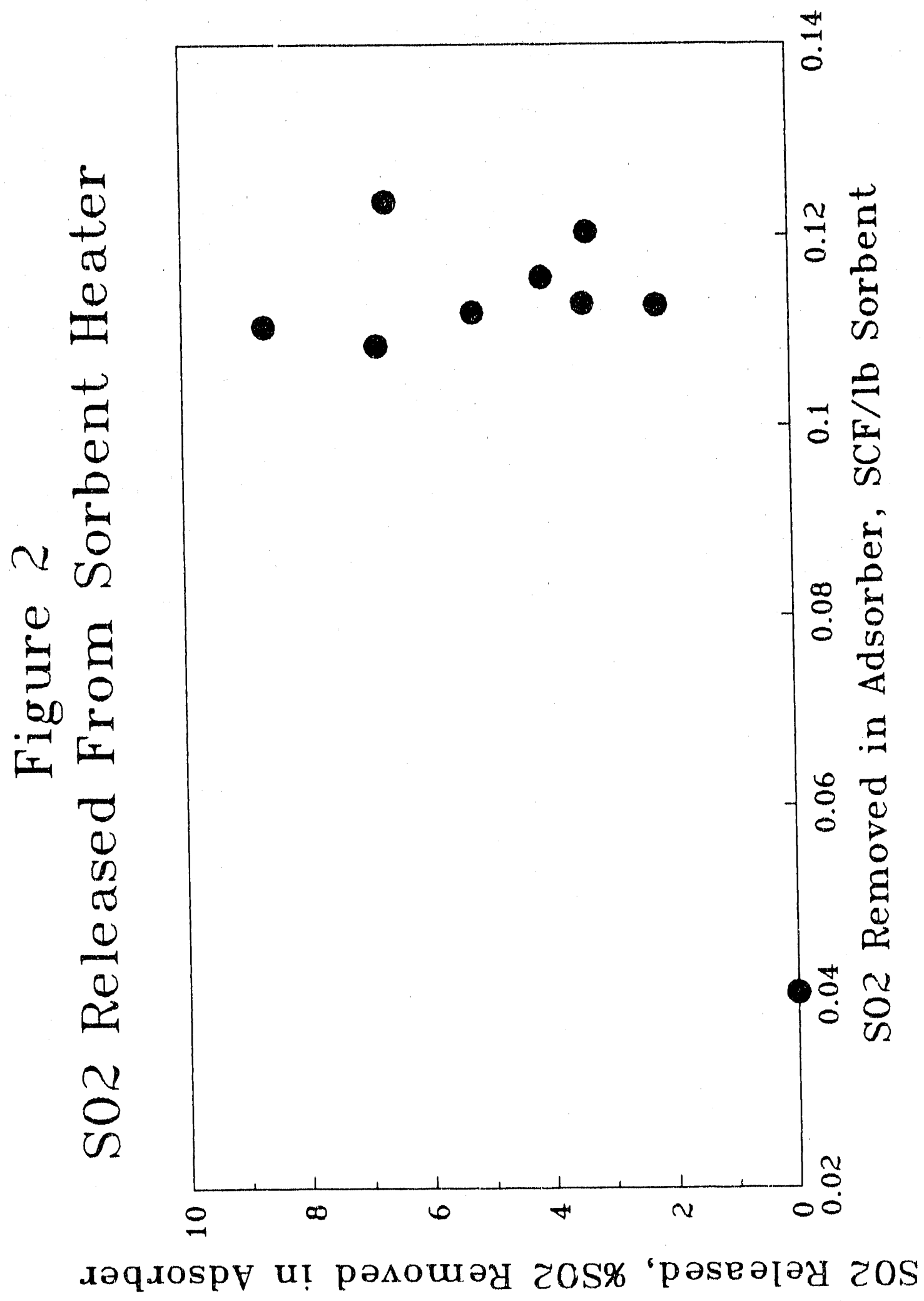


across the sorbent bed, and 115 SCFM flue gas flow, but with sorbent recirculation rate at $1.5 \mathrm{lb} / \mathrm{min}, 1.0 \mathrm{lb} / \mathrm{min}$, and $0.5 \mathrm{lb} / \mathrm{min}$, respectively. The $\mathrm{SO}_{2}$ removal was $92 \%, 88 \%$, and 868 respectively, and $\mathrm{NO}_{x}$ removal was $55 \%$, 47\%, and $27 \%$ respectively. The eflect of sorbent feed rate would be more pronounced than it appears if the sorbent regeneration time was kept equal during the three tests. The regeneration time for Test $13 \mathrm{C}$ was $80 \mathrm{~min}$. compared with $240 \mathrm{~min}$, for Test $13 \mathrm{~F}$. If the regeneration time for test $13 \mathrm{C}$ was also $240 \mathrm{~min}$., the sorbent would have been more thoroughly regenerated (this can be judged by residual sulfur content on the regenerated sorbent), and the $\mathrm{SO}_{2}$ and $\mathrm{NO}_{\mathrm{x}}$ removal would be expected to be higher than the present value.

\subsubsection{Temperature Effect}

The adsorber temperature effect on $\mathrm{SO}_{2} / \mathrm{NO}_{X}$ removal were studied in Tests $14 \mathrm{~A}, 14 \mathrm{~B}$, and $14 \mathrm{C}$ as shown in Table 1 . The adsorber temperature was $260^{\circ} \mathrm{F}, 300^{\circ} \mathrm{F}$, and $350^{\circ} \mathrm{F}$, respectively, while other process conditions were maintained constant. The data show a trend of decreasing $\mathrm{SO}_{2}$ and ${ }^{\mathrm{NO}} \mathrm{x}$ removals at a higher adsorber temperature within the temperature range studied.

\subsubsection{S02 and Nox Concentration Effect}

The adsorber inlet $\mathrm{SO}_{2}$ and ${ }^{\mathrm{NO}} \mathrm{x}$ concentrations were varied while maintaining other process conditions at their respective levels. Data from $12 \mathrm{~B}$ and $12 \mathrm{C}$ show that higher ${ }^{\mathrm{NO}} \mathrm{x}$ inlet concentration has lower percentage removal of $\mathrm{NO}_{x}$. This was expected since the sorbent to the $\mathrm{NO}_{x}$ ratio was 
essentially decreased. However, the unit weight of $\mathrm{NO}_{2}$ removed per unit weight of sorbent usage increased from 0.0041 to $0.00441 \mathrm{~b} \mathrm{NO} \mathrm{N}_{2} / \mathrm{lb}$ sorbent, as shown in Table 1 for $12 \mathrm{~B}$ and $12 \mathrm{C}$. Please note that the international convention uses weight of $\mathrm{NO}_{2}$ removal as standard reference.

Inlet $\mathrm{SO}_{2}$ concentration was then varied while keeping the inlet ${ }^{\mathrm{NO}} \mathrm{X}$ concentration constant at $600 \mathrm{ppm}$ (see Tests $12 \mathrm{~B}$ and $12 \mathrm{E}$ ). The inlet $\mathrm{SO}_{2}$ concentration was $1500 \mathrm{ppm}$, and $3000 \mathrm{ppm}$, respectively. It is seen that $\mathrm{lb}$ $\mathrm{SO}_{2}$ removed/lb sorbent increased with increasing the inlet $\mathrm{SO}_{2}$ concentration.

\subsubsection{Residence Tine Effect}

The effect of adsorber residence time for the sorbent on $\mathrm{SO}_{2}$ and ${ }^{\mathrm{NO}} \mathrm{x}$ removal is shown in Tests $12 \mathrm{~F}$ and $12 \mathrm{G}$. The sorbent residence time in the adsorber is proportional to the sorbent inventory in the adsorber. By keeping other process variables constant, it is seen that longer sorbent residence time in the adsorber enhanced $\mathrm{SO}_{2}$ and $\mathrm{NO}_{x}$ removal. The $\mathrm{SO}_{2}$ removal was $81 \%$ and $\mathrm{NO}_{\mathrm{X}}$ removal was 698 at $69 \mathrm{~min}$. residence time versus $74 \%$ $\mathrm{SO}_{2}$ removal and $41 \% \mathrm{NO}_{\mathrm{x}}$ removal at $41 \mathrm{~min}$. residence time.

\subsection{Regenerator Parametric Study}

\subsubsection{Bydrogen Versus Natural Gas}

Both hydrogen gas and natural gas (over $90 \%$ are methane) are effective regenerants as shown in Table 1. Hydrogen gas was used as the regenerant in 
Tests 11 and 12 , and natural gas was used as the regenerant in Tests 13 through 15. However, natural gas must operate at a slightly higher regeneration temperature than hydrogen gas to be effective.

\subsubsection{Temperature Effect.}

Hydrogen gas was an effective regenerant at $560^{\circ} \mathrm{C}\left(1040^{\circ} \mathrm{F}\right)$ as shown in Test $12 \mathrm{C}$. In contrast, natural gas became totally ineffective at $566^{\circ} \mathrm{C}$ $\left(1051^{\circ} \mathrm{F}\right)$ regeneration temperature in Test $15 \mathrm{~B}$. The residual sulfur after regeneration was as high as $2.4 \%, \mathrm{SO}_{2}$ removal was only $25 \%$, and $\mathrm{NO}_{\mathrm{x}}$ removal was $7 \%$. This indicates that the regeneration reaction has virtually stopped at this low temperature. The regeneration temperature must be at least $594^{\circ} \mathrm{C}\left(1100^{\circ} \mathrm{F}\right)$ for natural gas to be effective. The remainder of Test 15 indicates the importance of a higher regeneration temperature. Table 1 shows that sorbent regenerated with natural gas contains less residual sulfur than sorbent regenerated with hydrogen even though the effective regeneration temperature differential should be noted.

\subsubsection{Steam Effect}

Steam mixed with natural gas as a regenerant helped in reducing residual sulfur in the sorbent after regeneration. This can be seen by comparing Test $15 \mathrm{C}$ (with steam in the regenerant and 2.18 by volume excess $\mathrm{CH}_{4}$ concentration in the regenerator offgas) and Test $15 \mathrm{~F}$ (without steam in the regenerant and 2.18 by volume excess $\mathrm{CH}_{4}$ concentration in the regenerator offgas). Aiter regeneration, the residual sulfur in Test $15 \mathrm{C}$ 
was 0.358 compared with 0.728 residual sulfur in Test $15 \mathrm{~F}$. The same comparison may be made between Test 15D (with stean) and 15G (without. steam).

\subsubsection{Excess Methane Ef fect}

During the period of sorbent regeneration with natural gas (Tests 13 through 15), the methane concentration in the regenerator offgas was kept at approximately $10 \%$ by volume except in Tests $15 \mathrm{C} / \mathrm{E} / \mathrm{F}$. The purpose for the variation was to determine how much excess regenerant should be maintained in order to have a reasonable level of sorbent regeneration, since too much excess regenerant would have a negative effect on the process economics.

effect of excess methane on sorbent regeneration efficiency as measured by residual sultur is given in Table 10 .

Table 10. Effect of Excess Methane

$\begin{array}{lrrrrr}\text { Test No. } & 15 \mathrm{C} & 15 \mathrm{D} & 15 \mathrm{E} & 15 \mathrm{~F} & 15 \mathrm{G} \\ \text { Excess CH4, vol\% } & 2 & 10 & 20 & 2 & 10 \\ \text { Residual S, wt\% } & 0.35 & 0.18 & 0.13 & 0.72 & 0.62 \\ \text { SO2 removal eff., \& } & 74 & 72 & 74 & 67 & 70 \\ \text { NOx removal eff., \& } & 51 & 54 & 55 & 52 & 50 \\ \text { Steam used in regn. } & \text { yes } & \text { yes } & \text { yes } & \text { no } & \text { no }\end{array}$

Table 10 shows that the more excess regenerant used, the better the regeneration of the sorbent as indicated by the lower residual sulfur. This holds true whether or not steam was part of the regenerant. However, the resulting lower residual sulfur does not seen to have a significant effect on $\mathrm{SO}_{2}$ and $\mathrm{NO}_{\mathrm{x}}$ removal among Tests $15 \mathrm{C} / \mathrm{D} / \mathrm{E}$ and Tests $15 \mathrm{~F} / \mathrm{G}$, respectively. This indicates a diminishing return of benefits when residual sulfur on the 
regenerated sorbent is below about $0.35 \%$. This information must be taken into consideration when designing a commercial unit.

\subsubsection{Nitrogen Effect}

Nitrogen gas dilution of the regeneration gas was an optional mode when designing the LCTU. The purposes were 1) to better distribute the regeneration gas in the moving-bed regenerator because of uncertainties in the regeneration gas flow pattern in the moving packed bed, and 2) to provide an emergency purge of the combustible-gas filled regenerator. By comparing residual sulfur data in Test 15A1 (with nitrogen) and Test 15D (without nitrogen) in Table 1, we found that nitrogen dilution did not improve the sorbent regeneration efficiency. In Test $15 \mathrm{~A} 1$ the regenerated sorbent had 0.368 sulfur while in Test $15 \mathrm{D}$ it was $0.18 \%$. The $\mathrm{SO}_{2}$ and $\mathrm{NO}_{\mathrm{x}}$ removal. efficiencies between Test $15 \mathrm{~A} 1$ and Test $15 \mathrm{D}$ were similar.

\subsection{Sulfur Regeneration}

\subsubsection{Kinetics of Single-Vessel Regeneration}

Hydrogen and natural gas were used for the sulfur regeneration in the LCTU tests. Natural gas was first used in Test 1 but was stopped because of a lack of regeneration. Hydrogen was then used from Test 2 through Test 12. Meanwhile, laboratory studies found that the natural gas required a higher temperature for the regeneration than the LCTU regenerator could provide. 
After changing the heating capacity of the regenerator, a higher regeneration temperature could be reached from the time Test 13 started. The natural gas was used as a regenerant from Test 13 through Test 15 . The parametric tests for the regeneration study were mainly conducted during the natural gas regeneration. Table 11 summarizes the ranges of the test conditions.

Table 11. Test Conditions for Single Vessel Regeneration Using Natural Gas and Steam

\begin{tabular}{lrr} 
Variable & From & To \\
\hline Sorbent Sulfur Content After Adsorption, wt & 1.02 & 2.99 \\
Sorbent Sulfur Content After Regeneration, wt\% & 0.13 & 2.40 \\
Sorbent Residence Time, min & 80 & 240 \\
Regeneration Temperature, F & 1051 & 1136 \\
Inlet CH4 Concentration, volume \& & 20.9 & 92.1 * \\
Inlet Steam Concentration, volume 8 & 0.0 & 56.7 \\
Inlet N2 Concentration, volume \& & 0.0 & 54.7 \\
Superfacial Gas Velocity, ft/min & 0.8 & 6.3
\end{tabular}

* The methane content of natural gas.

The sorbent residence time was the only parameter varied during the hydrogen regeneration. To compare the regeneration between hydrogen and natural gas, a first order regeneration equation was proposed as follows:

$$
\frac{d s}{d t}=-k_{r}^{\prime} s
$$

where $S$ is the sulfur content on the sorbent, wt:

$t$ is the sorbent residence time in the regenerator, min

$K_{r}^{\prime}$ is the regeneration rate constant, $\min ^{-1}$; a function of

$r$ temperature and gas concentration. 


$$
\ln \frac{s_{\text {ads }}}{s_{\text {reg }}}=k_{r}^{\prime} t
$$

where $s_{\text {ads }}$ is the wto sulfur content after adsorption

$S_{\text {reg }}$ is the wts sulfur content after regeneration.

The data used for Equation 3 are the natural gas regeneration in Tests 13 and 14 , the regeneration with hydrogen and steam in sequence in Tests 2 and 4 , and the regeneration wiih hydrogen and steam together in T'ests 5 through 12. The temperature and concentration of the regenerants were constant in these tests. Since Test 15 was the parametric testing for the natural gas regeneration of which the gas concentrations were varied on purpose, its data was not used to compare with the hydrogen regeneration. The data of Tests 13 and 14 were grouped according to the sorbent residence time, and an average of each time period was plotted with the sulfur content according to Equation 3. The result is shown in Figure 3, which summarizes the residence time effect on the regeneration using different sorbent and regenerants. The value of $\mathrm{K}_{\mathrm{r}}^{\prime}$ (i.e., slope in Figure 3 ) for the $\mathrm{H}_{2} / \mathrm{steam}$ sequence is about half of that of $\mathrm{H}_{2}$ and steam together. This implies that the use of sequential hydrogen and steam treatment in one vessel actually cuts the sorbent-regenerant contact time in half. The higher regeneration temperature of the diluted natural gas (dil. NG) and steam gives a higher $k_{r}^{\prime}$ value than the $\mathrm{K}_{\mathrm{r}}^{\prime}$ of the $\mathrm{H}_{2}$ and steam regeneration. The effect of sorbent type on the regeneration kinelics is also shown in Figure 3, where Noxso-2 and NOXSO-4 sorbents were regenerated about $1060^{\circ} \mathrm{F}$ using hydrogen with 


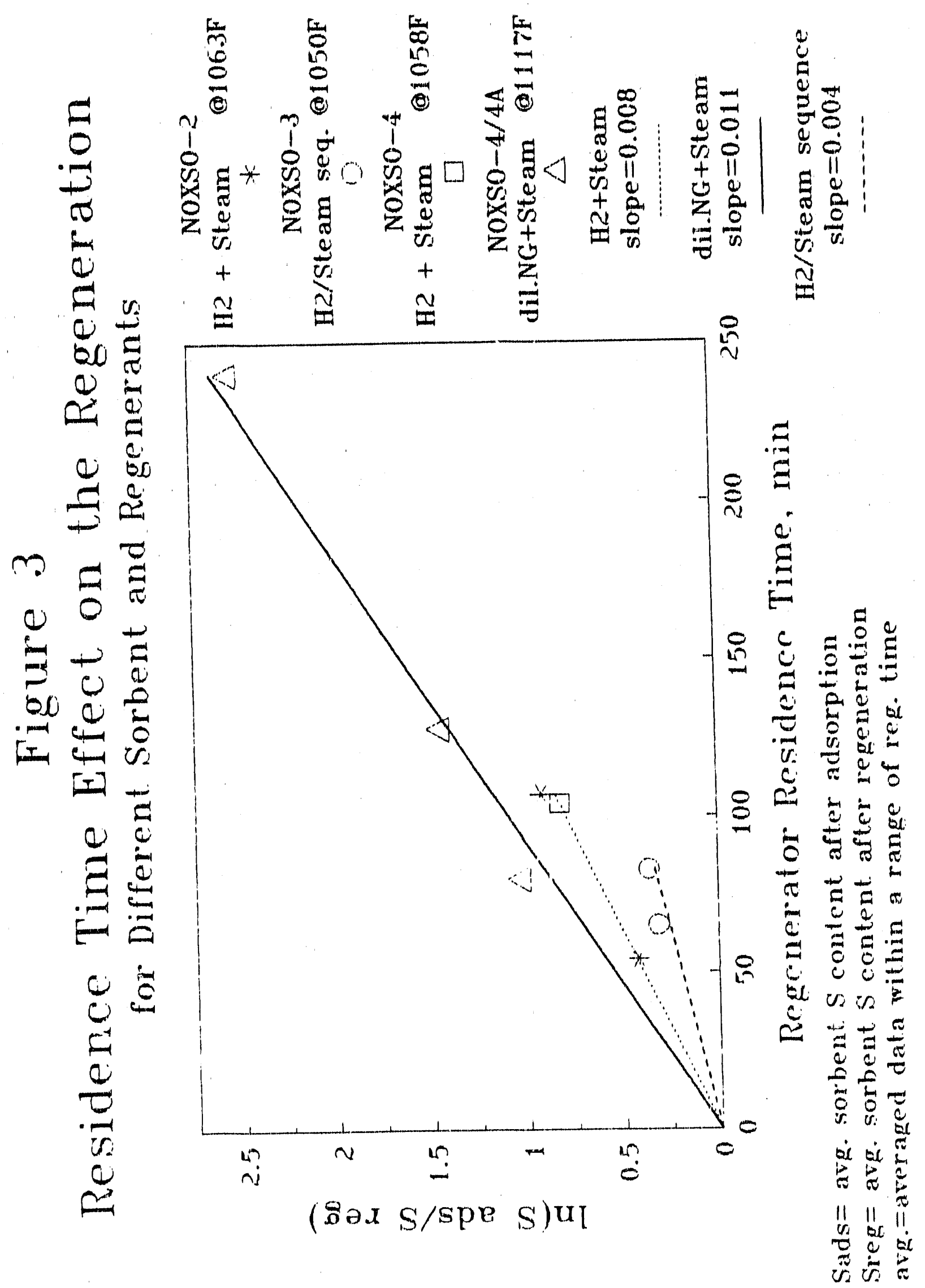


steam. Since both sorbents give a similar regeneration result, we conclude that the sorbent difference is not significant as compared to other effects on the regeneration.

The rate constant of Equation 3 is again used with Test 15 data to determine the effect of the gas velocfty on the regeneration. The result is shown in Figure 4 as a plot of $k_{r}^{\prime}$ versus superfictal gas velocity. Although a slight increase in $k_{r}^{\prime}$ was found with the increase of gas velocity, the contribution of increasing gas velocity on the regeneration rate is too small to be important.

To determine che gas concentration effect on the regeneration, the rate constant of Equation 3 was first plotted against the methane concentration as shown in Figure 5. An arithinetic average of the inlet and outlet metharie concentration was used in Figure 5 , because the integration of Equation 2 required a constant gas concentration. Although a log-mean average is better than an arithmetic average for a plug.flow reactor, the uncertainty of the water content of the regenerator offgas makes the outlet methane concentration uncertain, which is a dry measurement. Since the uncertainty of the outlet methane concentration will be carried into the final results, it becomes meaningless io use a difficult average. An arithmetic average is therefore selected to simplify the analysis. The data in Figure 5 shows that the rate constant increases linearly with the $\mathrm{CH}_{4}$ concentration. Equation 2 can be rewritten as follows:

$$
\frac{d s}{d t}=-K_{r} P^{a+1} y_{H 2 O^{y}}^{a} \mathrm{CH}_{4} S
$$




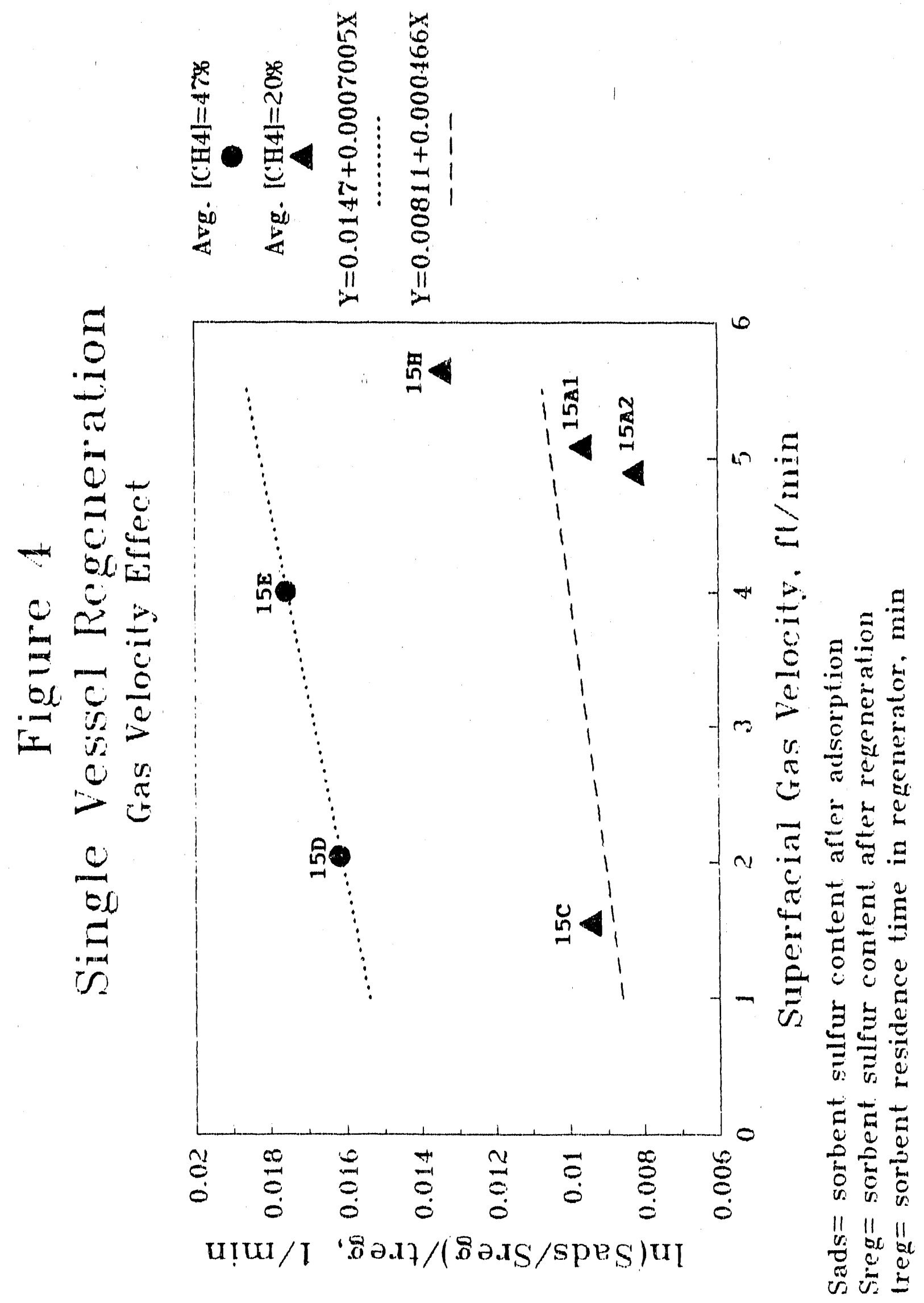




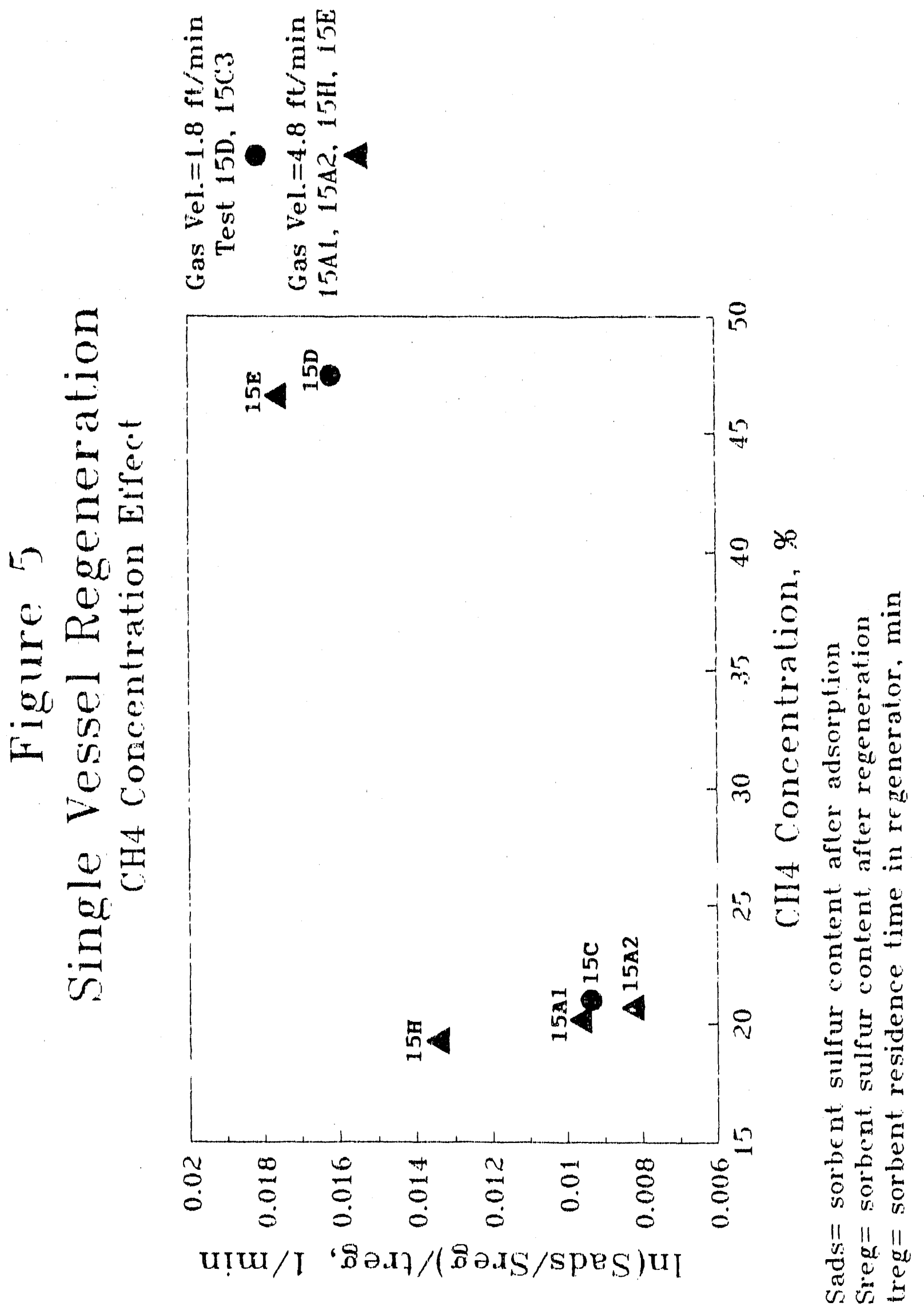


where $k_{r}$ is the regeneration rate constant, $\min ^{-1} \operatorname{atm}^{-(a+1)}$;

a function of temperature only

$y_{\mathrm{CH} 4}$ is the methane mole fraction

$\mathrm{y}_{\mathrm{H} 2 \mathrm{O}}$ is the steam mole fraction

$P \quad$ is the total pressure of the system, atm

a is the order of $\mathrm{y}_{\mathrm{H} 2 \mathrm{O}}$

Integrating Equation 4 with an averaged $\mathrm{y}_{\mathrm{CH} 4}$ and $\mathrm{y}_{\mathrm{H} 2 \mathrm{O}^{\prime}}$ and replacing the pressure with 1 atm gives:

$$
\ln \frac{s_{\text {adis }}}{s_{\text {reg }}}=+k_{r} y_{C H 4} y_{H 2 O}^{a} t
$$

or

$$
\ln \frac{s_{\text {ads }}}{s_{\text {reg }}} / t / y_{\mathrm{CH} 4}=K_{r} y_{\mathrm{H} 2 O}^{a}
$$

A plot of $\ln \left(\mathrm{s}_{\mathrm{ads}} / \mathrm{S}_{\mathrm{reg}}\right) / \mathrm{t} / \mathrm{y}_{\mathrm{CH} 4}$ versus $\mathrm{y}_{\mathrm{H} 2 \mathrm{O}}$ as shown $i n$ Figure 6 indicates that the rate of regeneration is linear as long as the inlet steam concentration is less than 25\%. Since the water content of the regenerator of fgas was not known, the inlet steam concentration was used in Figure 6 .

To determine the temperature dependence of the regeneration, the rate constant was first calculated according to Equation 6 . The value of $K$ was then plotted against the regeneration teirperature according to the Arrhenius' law, as shown in Figure 7. A least-square method yields the best fit result as follows:

$$
\text { In } \mathrm{K}_{\mathrm{r}}=54.35918-48946.9 / \mathrm{T} \quad \text { ( } \mathrm{T} \text { in Kelvin) }
$$




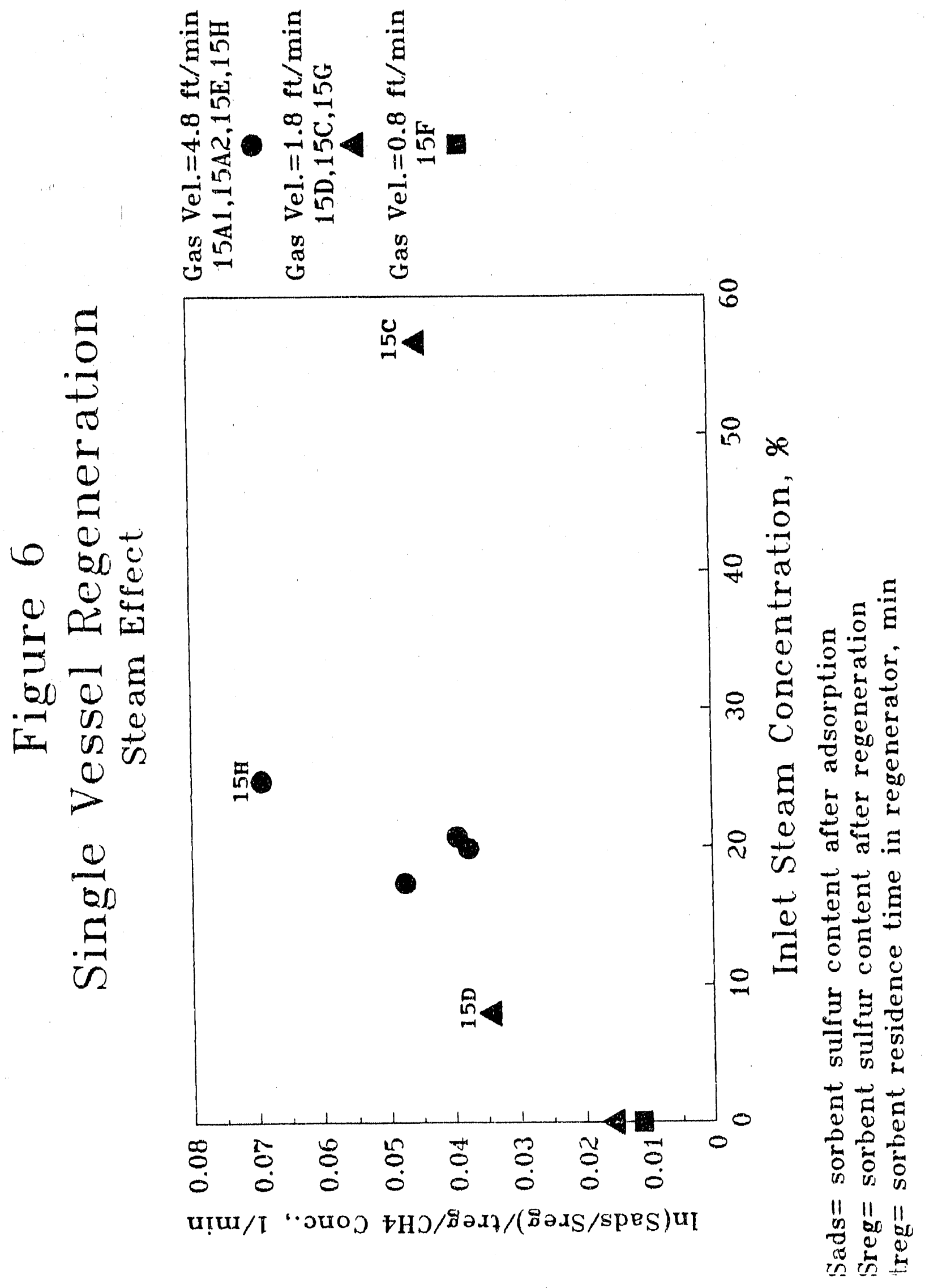




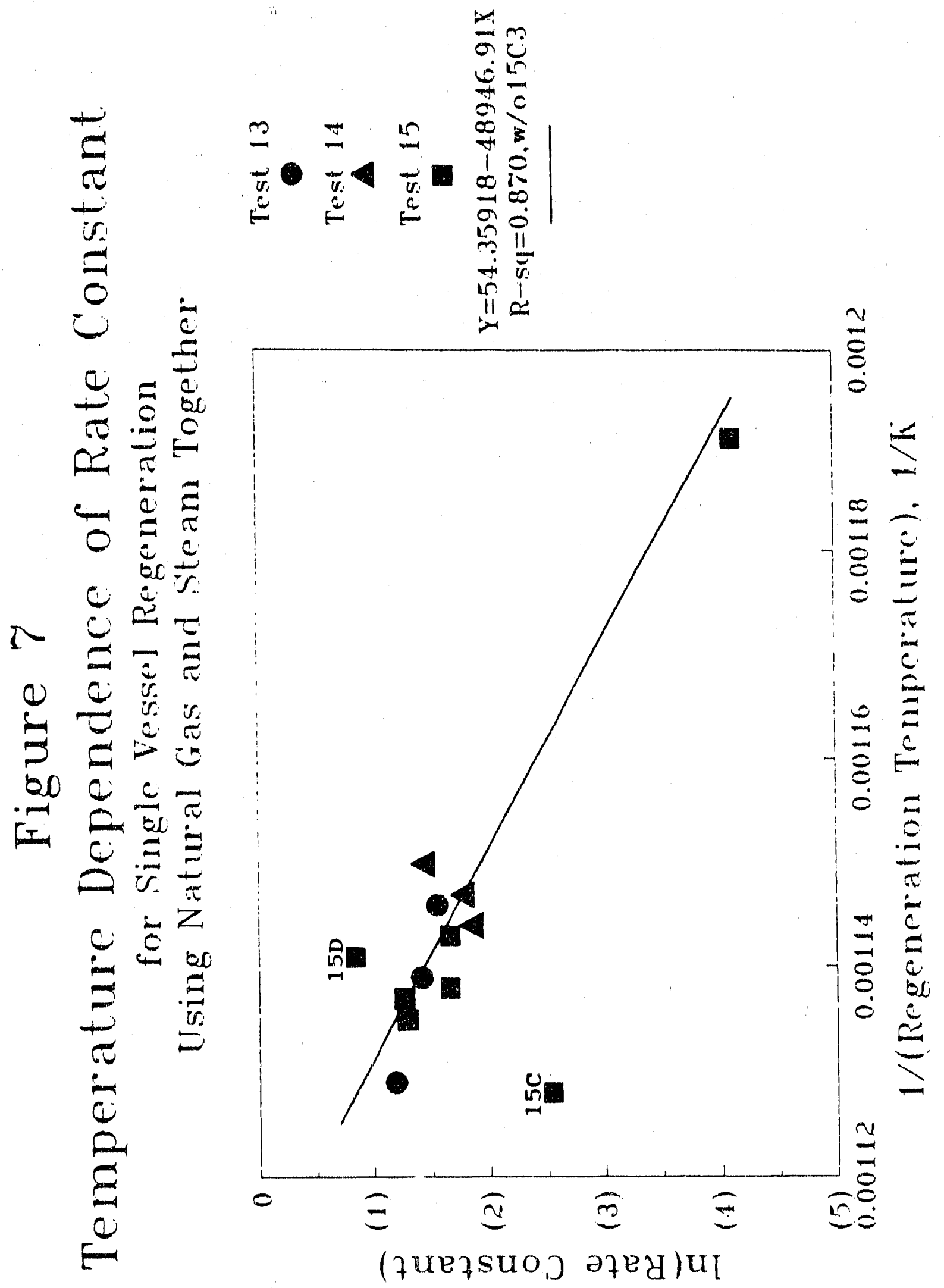


The correlation coefficient is 0.870 for all of the natural gas and steam regeneration data except Test $15 \mathrm{C}$, which has $56.7 \%$ inlet steam concentration. As Figure 6 indicates, the rate of regeneration linearly increased with steam concentration up to 258 . Using a steam concentration greater than 25\% may inhibit the regeneration.

In summary, we conclude that the natural gas regeneration is a first order reaction with respect to the sulfur content, methane concentration, and steam concentration. The use of steam does help the sulfur regeneration, but the steam concentration should be limited to less than 258.

Furthermore, the residual sulfur content of the regenerated sorbent can be estimated by combining Equations 5 and 7 and rewriting the equation in the following form.

$$
S_{r e g}=\frac{S_{a d s}}{\exp \left[\exp (54.35918-48946.9 / T) y_{\left.\mathrm{CH}_{4}{ }_{\mathrm{H} 2 O} t\right]}\right.}
$$

where $S_{\text {ads }}$ is the sulfur content after adsorption, wt\%

$s_{\text {reg }}$ is the sulfur content after regeneration, wto

$\mathrm{T}$ is the regeneration temperature, $\mathrm{k}$ $y_{\mathrm{CH} 4} \begin{aligned} & \text { is the averaged mole fraction of the inlet and outlet } \mathrm{CH}_{4} \\ & \text { concentration }\end{aligned}$

$\mathrm{y}_{\mathrm{H} 2 \mathrm{O}}$ is the inlet steam mole fraction

$t$ is the sorbent residence time in the regenerator, min 
Equation 8 was used with the parametric data of regeneration to estimate the residual sulfur content on the regenerated sorbent. The data and the results are tabulated in Table 12. It should be pointed out that some of the tabulated data points, 1.e., 13B, 13C, 13D, 13E, 13F, and 13G, do not have the measured sulfur content after the adsorption. The values of these data listed in Table 12 were estimated from the mole of $\mathrm{SO}_{2}$ removed in the adsorber. It was calculated from the flue gas flowrate, the inlet $\mathrm{SO}_{2}$ concentration and the $\mathrm{SO}_{2}$ removal efficiency. The mole of removed $\mathrm{SO}_{2}$ was then converted into the weight percentage based on the sorbent flowrate. The estimated percentage sulfur content after the adsorption is given by:

$$
S_{\text {ads }}=S_{\text {reg }}+\frac{\frac{F_{G} 0.92}{379} \frac{[S 02] E}{10^{8}} 32}{F_{S}} 100
$$

where $F_{G}$ is the flue gas flowrate, SCFM $60^{\circ} \mathrm{F}, 1$ atm

$\mathrm{SO}_{2}$ is the inlet $\mathrm{SO}_{2}$ concentration, $\mathrm{ppm}$

$\mathrm{E}$ is the $\mathrm{SO}_{2}$ removal efficiency, \%

$\mathrm{F}_{\mathrm{S}}$ is the sorbent flowrate, Jb/min

32 is the molecular weight of sulfur, 1b/1bmole

0.92 is the dry gas volume fraction in the flue gas

379 is the mole gas volume at $60^{\circ} \mathrm{F}, 1 \mathrm{~atm}, \mathrm{ft}^{3} / 1 \mathrm{bmole}$

The comparison between Equation 8 predicted sulfur content and the experimentally measured sulfur content of the regenerated sorbent is shown In Figure 8. I' is noted that three data points listed in Table 12 are not included in Figure 8. They are 15G, 15F, and 15C. Data 15G and 15F have a zero inlet steam concentration, which automatically makes Equation 8 
Table 12. Parametric Study Data for Regeneration

\begin{tabular}{|c|c|c|c|c|c|c|c|}
\hline $\begin{array}{l}\text { Test } \\
\text { No.\# }\end{array}$ & $\begin{array}{l}\text { Nitrogen } \\
\text { SCFH } \\
\end{array}$ & $\begin{array}{l}\text { Steain } \\
\underline{1 b / h r}\end{array}$ & $\begin{array}{l}\text { N.G. } \\
\text { SCFM }\end{array}$ & $\begin{array}{l}\text { Nitrogen } \\
\text { vol. } 8 \\
\end{array}$ & $\begin{array}{l}\text { Steam } \\
\text { vol.8 } \\
\end{array}$ & $\begin{array}{r}\mathrm{CH} 4 \\
\mathrm{vol} .8 \\
\end{array}$ & $\begin{array}{c}\text { CH4 of fgas } \\
\text { vol.8 } \\
\end{array}$ \\
\hline $13 \mathrm{~A}$ & 50.0 & 0.75 & 25.6 & 54.71 & 17.28 & 25.80 & 10.0 \\
\hline $13 B$ & 0.0 & 0.78 & 27.0 & 0.0 & 37.82 & 57.27 & 9.5 \\
\hline $13 \mathrm{C}$ & 45.5 & 0.78 & 27.0 & 51.17 & 18.47 & 27.96 & 8.7 \\
\hline 13D & 46.2 & 0.71 & 27.0 & 52.41 & 16.96 & 28.21 & 9.1 \\
\hline $13 \mathrm{E}$ & 46.2 & 0.78 & 27.0 & 51.55 & 18.32 & 27.75 & 10.8 \\
\hline $13 \mathrm{~F}$ & 45.8 & 0.88 & 26.3 & 50.54 & 20.44 & 26.73 & 12.5 \\
\hline $13 \mathrm{G}$ & 45.5 & 0.85 & 26.3 & 50.73 & 19.95 & 27.00 & 13.3 \\
\hline $13 \mathrm{H}$ & 45.5 & 0.85 & 26.3 & 50.73 & 19.95 & 27.00 & 10.8 \\
\hline $14 \mathrm{~A}$ & 48.0 & 0.99 & 29.7 & 48.71 & 21.15 & 27.76 & 12.7 \\
\hline $14 \mathrm{~B}$ & 49.0 & 0.71 & 27.0 & 53.50 & 17.01 & 27.15 & 11.7 \\
\hline $14 \mathrm{C}$ & 41.9 & 0.60 & 27.0 & 51.39 & 15.49 & 30.50 & 11.1 \\
\hline $14 \mathrm{D}$ & 40.0 & 0.71 & 28.4 & 47.99 & 17.94 & 31.38 & 11.5 \\
\hline $14 \mathrm{E}$ & 49.6 & 0.85 & 28.4 & 51.72 & 18.66 & 27.28 & 11.9 \\
\hline $15 A 1$ & 38.3 & 0.65 & 26.5 & 48.80 & 17.44 & 31.10 & 9.2 \\
\hline $15 B$ & 46.2 & 1.05 & 20.1 & 52.26 & 25.01 & 20.94 & 11.3 \\
\hline $15 \mathrm{~A} 2$ & 34.1 & 0.75 & 25.9 & 44.99 & 20.84 & 31.47 & 9.9 \\
\hline $15 \mathrm{G}$ & 0.0 & 0.00 & 29.1 & 0.0 & 0.0 & 92.10 & 10.3 \\
\hline $15 \mathrm{~F}$ & 0.0 & 0.00 & 12.7 & 0.0 & 0.0 & 92.10 & 2.1 \\
\hline $15 \mathrm{D}$ & 0.0 & 0.12 & 29.2 & 0.0 & 7.964 & 84.77 & 10.2 \\
\hline $15 \mathrm{C}$ & 0.0 & 0.64 & 10.3 & 0.0 & 56.68 & 39.90 & 2.1 \\
\hline $15 \mathrm{E}$ & 0.0 & 0.59 & 49.8 & 0.0 & 19.97 & 73.71 & 19.5 \\
\hline $15 \mathrm{H}$ & 38.0 & 1.03 & 27.6 & 43.53 & 24.85 & 29.12 & 9.4 \\
\hline
\end{tabular}


Table 12. Parametric Study Data for Regeneration (continued)

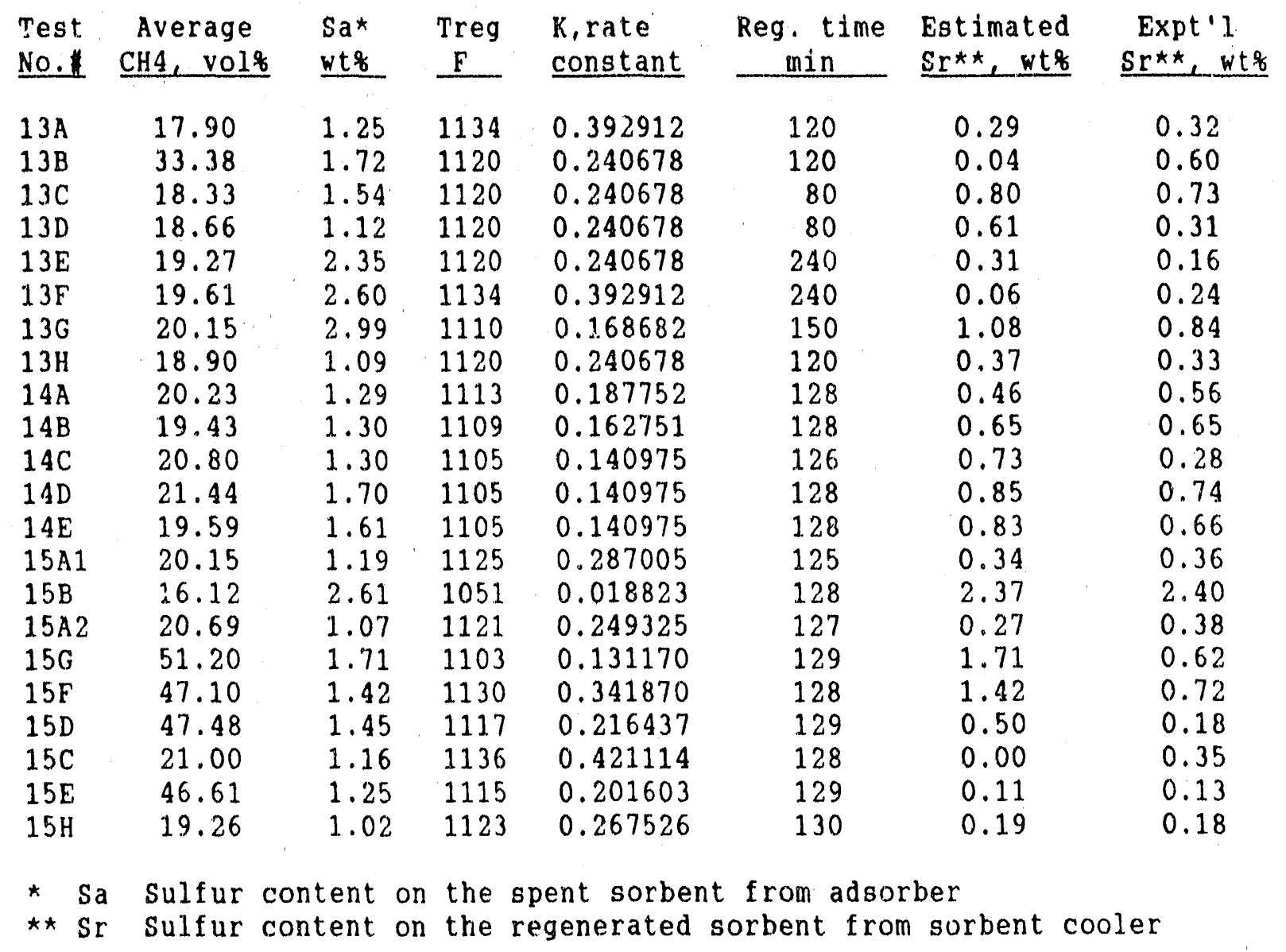




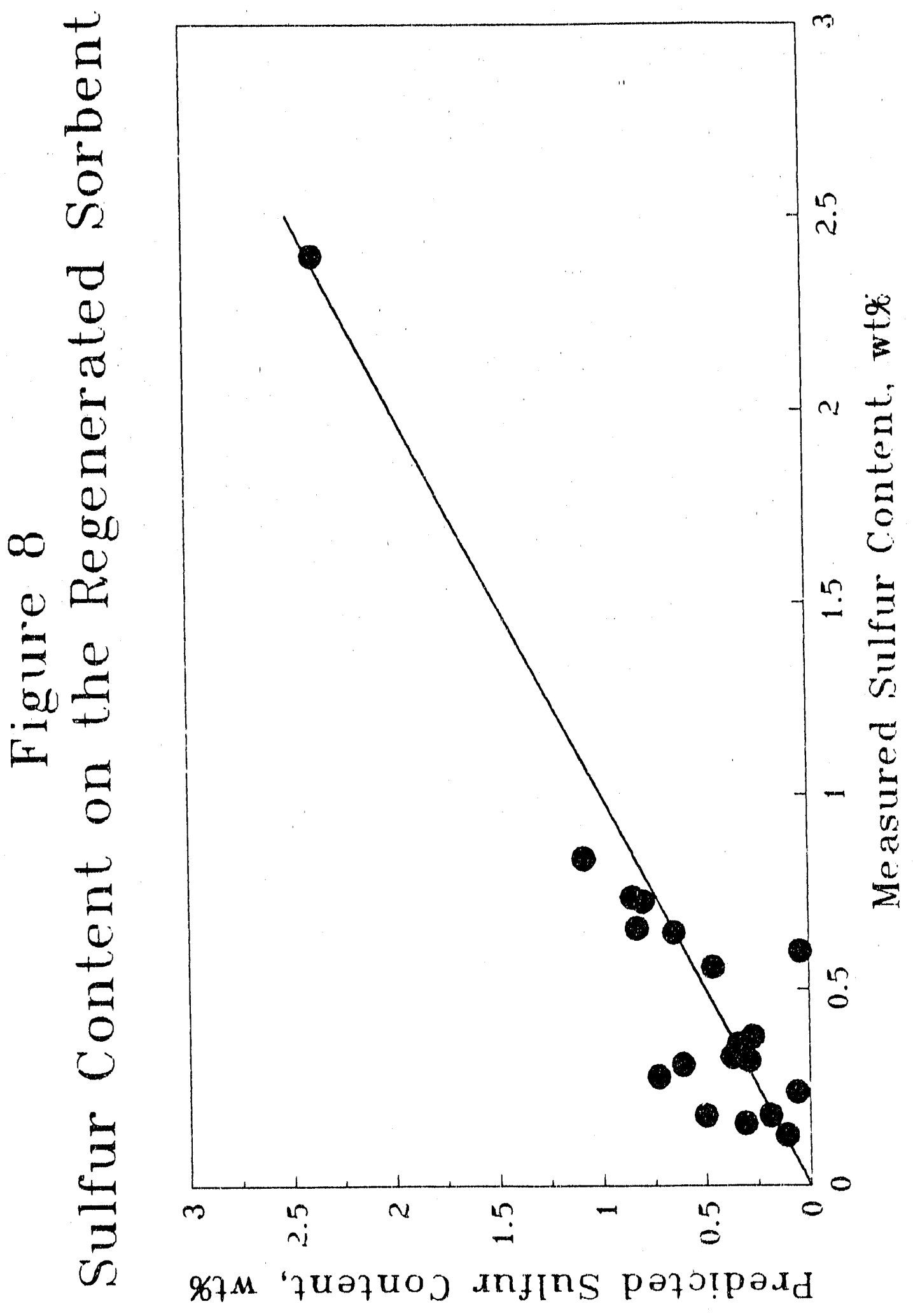


invalid. Data $15 \mathrm{C}$ has $56.7 \%$ inlet steam concentration which exceeds the limit of inlet steam concentration, 25\%, for applying Equation 8 . Because of the good agreement between the measured and predicted sulfur content as shown in Figure 8, we suggest that Equation 8 be used as a design equation for a single-vessel regenerator operating under 1 atmosphere with the inlet steam concentration greater than zero, but less than $25 \%$.

\subsubsection{Sulfur Product Distribution}

It has previously been reported that different types of reducing gases generate different amounts of regeneration products [5]. Table 13 summarizes the relative quantities of reaction products produced in all test work to date. The results obtained using $\mathrm{H}_{2}$ and $\mathrm{CO}$ in the $0.75 \mathrm{MW}$ tests confirm results obtained in the pre-pilot tests. Natural gas was used as a reductant for the first time in the $0.75 \mathrm{MW}$ test.

Table 13. Relative Distribution of Reaction Products on Sorbent Regeneration [1]

Reducing Gas

$\frac{\% \text { SULFUR REGENERATED }}{\underline{\mathrm{SO} 2}} \underline{\mathrm{H} 2 \mathrm{~S}} \underline{\mathrm{COS}} \quad \underline{\text { Sulfur* }}$

$\mathrm{H} 2$

$\mathrm{CO}$

$\mathrm{H} 2 / \mathrm{CO}$

$\mathrm{H} 2 \mathrm{~S}$

CH 4

\section{4}

30

46

17

35
27

62

49

35

55

$\begin{array}{lr}- & 9 \\ - & 8 \\ - & 5 \\ - & 48 \\ 3 & 7\end{array}$

* Not measured. Sulfur deposits were found in the gas sampling lines. The amount of sulfur produced on regeneration was obtained by difference from the mass balance. 
In a commercial use of the NOXSO process, the $\mathrm{SO}_{2}$ and $\mathrm{H}_{2} \mathrm{~S}$ produced in the sorbent regenerator would be processed in a claus reactor to form elemental sulfur, which would then be sold as a by-product of the process. Claus reactors require a spectfic ratio of $\mathrm{H}_{2} \mathrm{~S}: \mathrm{SO}_{2} \quad(2: 1)$ in the inlet streatn. Since, in the NoxSO process, the ratio of $\mathrm{H}_{2} \mathrm{~S}_{2} \mathrm{SO}_{2}$ varies with the type of reducing gas used, it might be possible to select a combination of reducing gases that produces the ratio required by a claus reactor.

\subsection{Duration Test}

The parametric study and the duration test were conducted simultan.* eously in the LCTU. Overall, four kinds of sorbent were tested. They are NOXSO-2, NOXSO-3, NOXSO-4, and vOXSO-4A. The first sorbent used in the LCTU was NOXSO-3. Tests on NOXSO-3 were aborted after 63 regeneration cycles. The Noxso-3 sorbent had a severe attrition 10ss, $0.743 \mathrm{lb} / \mathrm{hr}$. Then the NOXSO-2 sorbent, which was previously regenerated 16 times in the 0.75 MW test, was loaded into the LCTU. The test continued unt11 NOXSO-2 accumulated a total of 93 regeneration cycles. At that time, the LCTU was upgraded so that the regenerator could operate at a higher temperature for testing natural gas regeneration. The NOXSO-2 gorbent which had a moderate attrition loss, $0.42 \mathrm{lb} / \mathrm{hr}$, was replaced by NOXSO-4. After 82 regeneration cycles with NOXSO-4, NOXSO-4A was used as sorbent makeup. The attrition loss of NOXSO-4 was $0.63 \mathrm{lb} / \mathrm{hr}$, while NOXSO-4A was $0.59 \mathrm{lb} / \mathrm{hr}$. Since the physical properties of NOXSO-4 were similar to NOXSO-4A, the NOXSO-4 was considered the same as NOXSO-4A in this report and was designated as NOXSO-4A. The total regeneration cycles of NOXSO-4A was 220 . 
The $\mathrm{NO}_{x}$ and $\mathrm{SO}_{2}$ removal efficiencies are a complex function of sorbent surface area, sodium content, resldual sulfur content, gas superfictal velocity, sorbent residence time, and gas-golid mixing conditions. The effects of these variables on the removal efficiencies are discusged in Section 4.8 .

\subsubsection{No $x$ Removal}

Since NOXSO-4A has more operating hours than other sorbents, its performance and physical properties are used to define the results for the duration test. The $\mathrm{NO}_{x}$ and $\mathrm{SO}_{2}$ removal efflciency of the bage-case tegt for NOXSO-4A was plotted against the number of regeneration cycles as shown in Figure 8. The base-case test condition was one $1 \mathrm{~b} / \mathrm{min}$ sorbent flow rate to treat 120 SCFM flue gas at $275^{\circ} \mathrm{F}$. The flue gas contained $1500 \mathrm{ppm} \mathrm{SO}_{2}$ and $600 \mathrm{ppm} \mathrm{NO} x$. Figure 9 shows that the $\mathrm{NO}_{x}$ removal efticlency decreases very rapidy in the first 30 cycles from $90 \%$ removal down to 55\%. After that, the NO $x$ removal efficiency oscillates between $46 \%$ and $56 \%$. The decrease in ${ }^{N} x_{x}$ removal efficiency with cycles is similar to the decrease in sorbent surface area. The variation of the sorbent surface area is superimposed on the ${ }^{N O} x$ removal efficiency in Figure 9 to show the similarity. The cause and the rate of the surface-area decrease will be discussed in section 4.7 .4 .

The ${ }^{N O} x$ removal was very sensitive to sorbent flow interruption into the adsorber. When interruption of sorbent flow into the adsorber occurs, the drop in $\mathrm{NO}_{x}$ removal efficiency can be observed immediately, while $\mathrm{SO}_{2}$ 


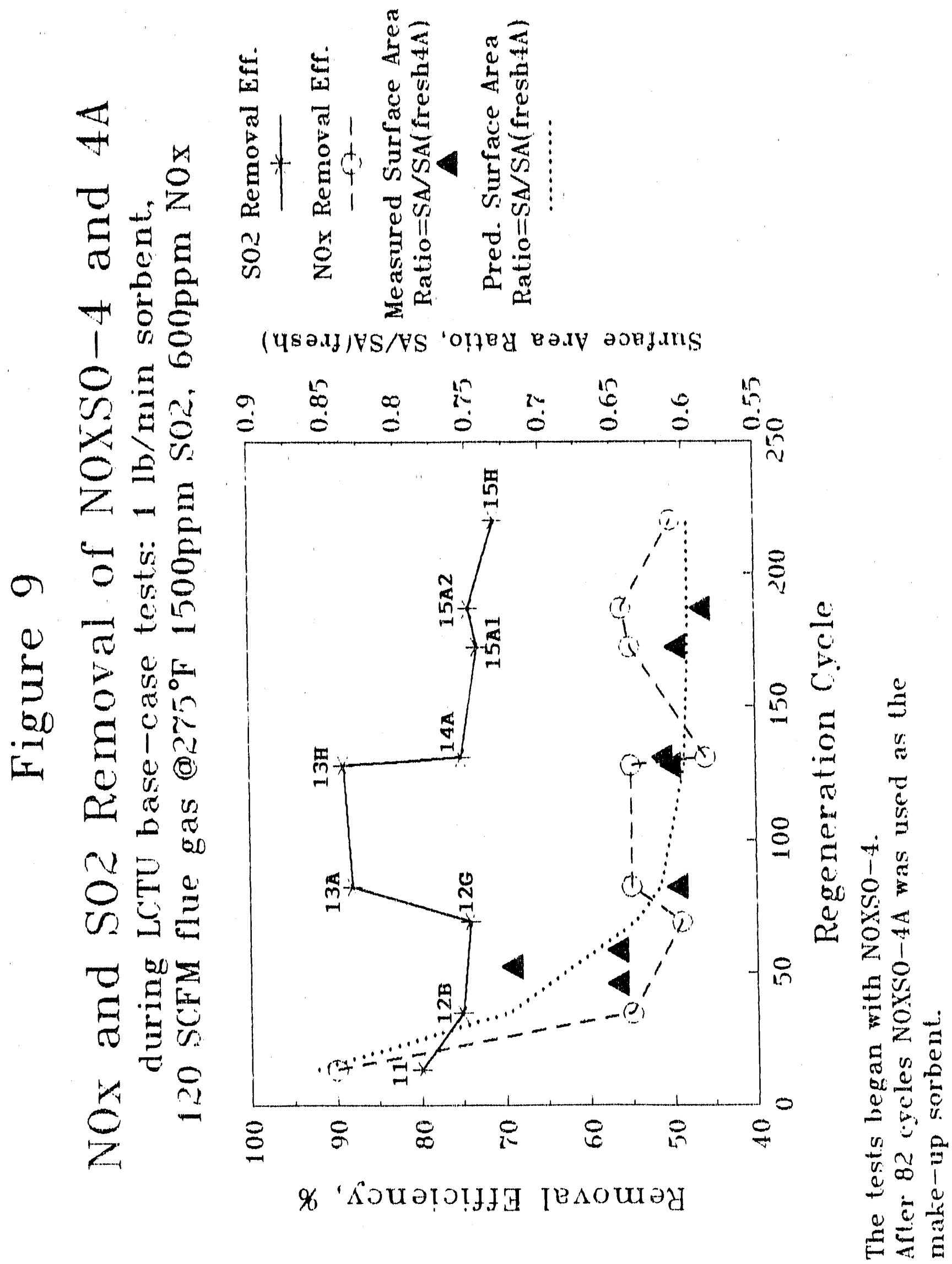


removal continues at the same level for a long period of time. This transient observation indicates the competition for sorbent aites between $\mathrm{SO}_{2}$ and $\mathrm{NO}_{\mathrm{X}}$. It has been observed that already adsorbed $\mathrm{NO}_{x}$ was drtven of $f$ from the sorbent by $\mathrm{SO}_{2}$ even at the low adsorber temperature of $250^{\circ} \mathrm{F}$. This can be seen when the transient exit ${ }^{N O}{ }_{x}$ concentration from the adsorber was hisher than the inlet NO $_{x}$ concentration. This phenomena implies that high sulfur loading on the oorbent has a negative effect on NO$_{x}$ removal.

In this series of tests, NO removal was not maximized. NO $x$ removal may be enhanced by higher sorbent feed rate (more surface area), and better regeneraiton (lower sulfur loading).

\subsection{2 $\mathrm{SO}_{2}$ Removal}

The $\mathrm{SO}_{2}$ removal efficiency in Figure 9 shows a slight decrease with the increase in regeneration cycles. This slow change of the $\mathrm{SO}_{2}$ removal efficiency shares the same characteristics as the change of the sorbent sodium content, which is shown in Figure 10. Although there is a discrepancy between the sodium content reported from W.R. Grace Co, and the Pittsburgh Energy Technology Center (PETC) laboratories, both laboratory results show a sudden drop of sodium in the first ten regeneration cycles. The PETC results show a substantially lower sodium content than Grace between 30 to 160 regeneration cycles. The reason for this difference ts not known. 


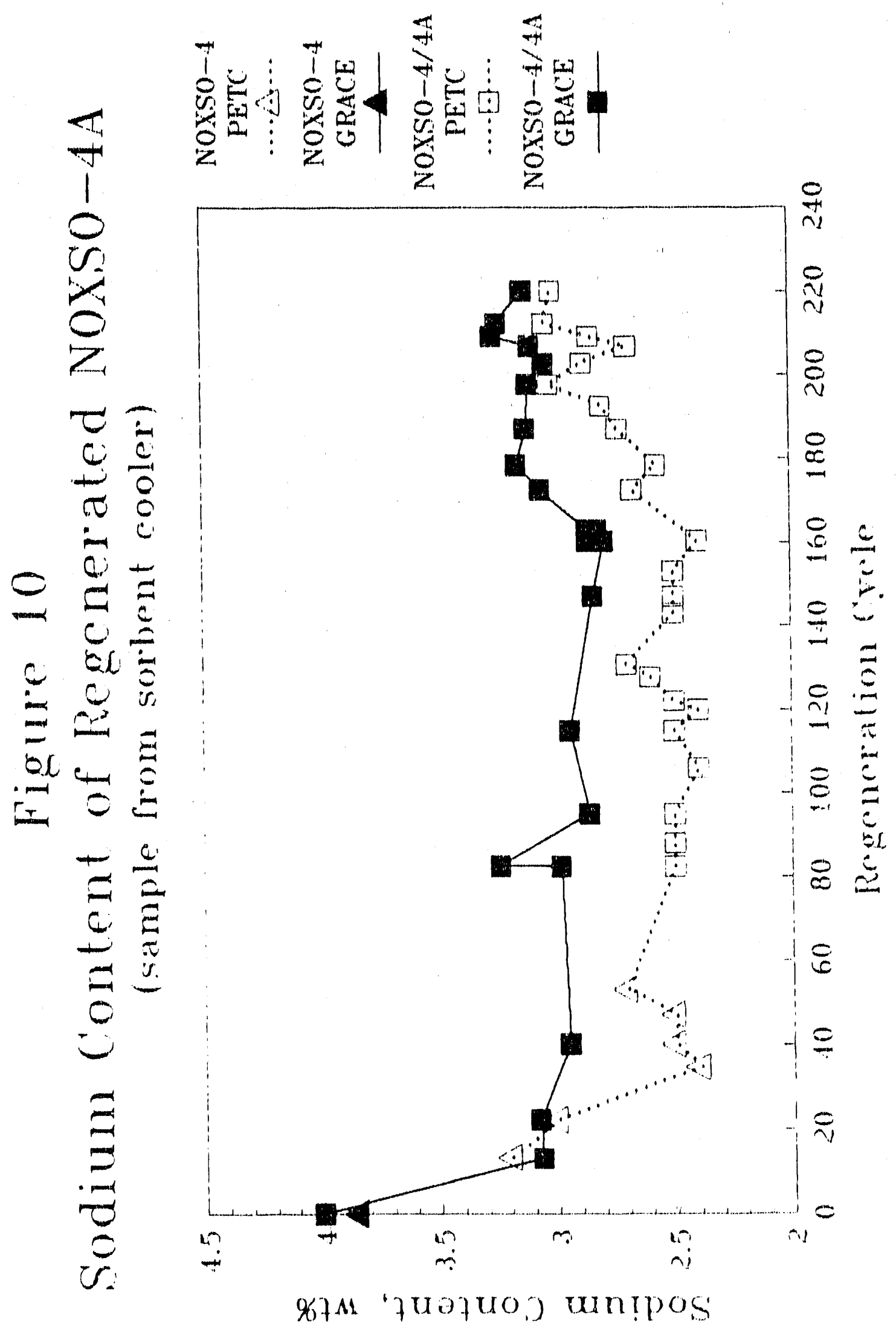


It should be noted that hydrogen was used as the regenerant from Test 11 through Test 12G. At the beginning of Test 13A (cumulative cycle 70) natural gas was used as the regenerant until the end of this test series. The sudden increase in $\mathrm{SO}_{2}$ removal in $13 \mathrm{~A}$ over $12 \mathrm{G}$ was probably due to more efficient sorbent regeneration by the natural gas. Table 1 shows that Test $12 \mathrm{G}$ has $1.0 \%$ residual sulfur in the regenerated sorbent, while the regenerated sorbent in Test $13 \mathrm{~A}$ has $0.32 \%$ residual sulfur. It is more difficult to explain the drop in $\mathrm{SO}_{2}$ removal in Test $14 \mathrm{~A}$ because there was no change in process conditions or the regenerant. However, there was a gradual replacement of NOXSO-4 sorbent by NOXSO-4A sorbent. The NOXSO-4 make-up sorbent was depleted during Test 13 and NOXSO-4A was used as the make-up sorbent during Test 13 and thereafter. It was estimated that about half of the sorbent inventory in the system was NOXSO-4A sorbent during Test 14A. It is possible that sorbent structure not only affects its attrition property but also affect $\mathrm{SO}_{2} / \mathrm{NO}_{\mathrm{X}}$ removal efficiencies.

The lower $\mathrm{SO}_{2}$ removal in Test $12 \mathrm{~B}$ and $12 \mathrm{G}$ compared with Test 11 probably can be explained by the fact that fresh sorbent was used in Test 11. Fresh sorbent has both higher sodium conterit and higher surface area and both have a positive effect on $\mathrm{SO}_{2}$ removal.

Again, in this series of tests, $\mathrm{SO}_{2}$ removal was not maximized. Higher $\mathrm{SO}_{2}$ removals were reported in [1], [3], and [4] at different process conditions and with different batches of sorbent. 


\subsubsection{Sorbent Sodium Content}

To explore the phenomena of sodium detrition, Grace sieved 1.6. $\mathrm{lbs}$ of NOXSO-4A, which had been through 163 regeneration cycles, into different size fractions and then measured the bulk sodium content of each size fraction. The results are listed in Table 14 .

Table 14. Sodium Content of Various Particle sizes for NOXSO-4A After 163 Regeneration Cycles

\begin{tabular}{|c|c|c|c|c|c|}
\hline \multicolumn{2}{|c|}{ Particle size } & \multicolumn{2}{|c|}{ Wtq of Total } & \multicolumn{2}{|c|}{$\mathrm{Na}, w t z$} \\
\hline Mesh & Micron & 163 Cycle & Fresh & 163 Cycle & Fresh* \\
\hline+10 & $2000<d$ & 0.012 & 0.1 & & \\
\hline$-10+12$ & $1700<d<2000$ & 2.04 & - & 2.75 & 4.0 \\
\hline$-12+14$ & $1400<d<1700$ & 21.6 & -- & 2.85 & 4.0 \\
\hline$-14+16$ & $1180<d<1400$ & 37.7 & 87.4 & 3.05 & 4.0 \\
\hline$-16+18$ & $1000<d<1180$ & 18.4 & -- & 3.11 & 4.0 \\
\hline$-18+20$ & $850<d<1000$ & 5.6 & 10.3 & 3.04 & 4.0 \\
\hline-20 & $d<850$ & 15.0 & 2.1 & 3.01 & 4.0 \\
\hline
\end{tabular}

Although the variation in sodium content listed in Table 14 is small, the data does show a trend between the sorbent size and the sodium content. The smaller the size is, the higher the sodium content will be. This trend is explainable. The smaller particles are more easily carried out of the test unit by the gas flow than the larger particles. If the sodium detrition is proportional to time, then the larger particles which remain in the system longer than the smaller particles vill have a lower sodium content than the small particles. 
The possibility of sodium migration toward the sorbent surface was also investigated by Grace. A series of experiments using NOXSO-4A which was treated to incipient wetness were conducted. The wet sorbent was then flash dried in an oven at the sorbent heater temperature. The purpose of Ilash drying the sorbent is to simulate the sudden change of temperatures between adsorber and sorbent heater. The sodium distribution across the sorbent was scanned before and after the experiments. Grace's results showed that the sodium would migrate toward the sorbent surface only when the following three conditions were met.

1. The sorbent was not calcined.

2. The sorbent was incipiently wet.

3. The sorbent was flash dried.

Therefore, the sodium migration could be stopped by using a calcined sorbent.

The presence of steam may be another reason for sodium detrition. The NOXSO laboratory had set up a bench-scale test to study the sodium content and the surface area decay for the fresh, uncalcined Noxso-4A. The sodium content dropped from 4 wto to 3.4 wts after 15 hours of steaming at $1175^{\circ} \mathrm{F}$. The details of the test are described in section 4.7 .4 , and the results are tabulated in Table 16 in the same section. 
The initial sodium detrition from $4 \%$ to $3 \%$ in a short period during the LCTU test could be the combined results of using a uncalcined sorbent and steaming it at a high temperature. Figure 10 shows that the sodium loss occurred mainly in the first few cycles of regeneration. After that, the sodium content did not decrease further. So, it is quite easy to maintain a higher percentage of sodium throughout the future tests by simply increasing the initial sodium loading on the sorbent.

It is important to mention that all the sorbent used in the LCTU test was not calcined prior to use. The fresh sorbent was fed into the sorbent cooler, where the temperature was around $150^{\circ} \mathrm{F}$. Since calcination by the sorbent manufacturers will increase the sorbent cost, Noxso will continue to use uncalcined sorbent but will feed the fresh sorbent into the sorbent heater. The temperature of the sorbent heater is high enough to calcine the sorbent.

\subsubsection{Sorbent Surface Area Decay}

The surface area of NOXSO-2 and NOXSO-4A decreased very fast in the first 20 sorbent cycles. After a hundred hours of testing, the rate of surface area decay started to slow down. Since a constant flow of fresh sorbent was added into the test unit to compensate for the attrition loss, the surface area was expected to reach an equilibrium value. A backmix reactor model was used to correct the effect of the make-up sorbent on the surface area, so that the rate equation of surface area decay could be found. 


$$
\frac{d A}{d t}[W A]=F_{\text {in }} A_{0}-F_{\text {out }}{ }^{A}-\int r d W
$$

where $t$ is the time, $\mathrm{hr}$

$W$ is the sorbent inventory of the test unit, ib

A is the sorbent surface area, $\mathrm{m}^{2} / \mathrm{g}$

$A_{0}$ is the surface area of the fresh sorbent, $\mathrm{m}^{2} / \mathrm{g}$

$F_{\text {in }}$ is the sorbent makeup rate, $1 \mathrm{~b} / \mathrm{hr}$

$F_{\text {out }}$ is the sorbent attrition rate, $1 \mathrm{~b} / \mathrm{hr}$

$r$ is the decay rate of the sorbent surface area, $\mathrm{m}^{2} / \mathrm{g} . \mathrm{hr}$

Since the sorbent is continuously circulated through the entire test unit, the decay rate should be uniform in the test unit. After a long period of operation time, the sorbent inventory would reach a constant value, and the sorbent makeup rate would equal the attrition rate. Therefore, $W$ in Equation 10 can be factored out and rewritten as:

$$
\frac{d A}{d t}=a\left(A_{0}-A\right)-r
$$

where $a=F_{\text {in }} / W=F_{\text {out }} / W$ is the attrition rate in terms of the fraction of sorbent inventory loss per hour.

Because the functional form of the surface-area change was unknown, Equation 11 was first used to determine $r$, the rate of surface-area change. Equation 11 can be rewritten into a difierent equation as follows: 


$$
r=a\left(A_{0}-A\right)-\frac{\Delta A}{\Delta t}
$$

The values of the measured surface area are oscillatory due to the sorbent sampling technique and measurement errors. In order to obtain a meaningful rate value, a smooth curve was drawn through the measured surface area data points to eliminate the data oscillation. The rate value was then calculated according to Equation 12 using the surface area data read from the smooth curve. Believing a final stable sorbent surface area existed, we proposed the following rate equation for surface area change:

$$
r=-\frac{d A}{d t}=K\left[A-A_{=}\right]
$$

where $K$ is the decay rate constant, $1 / \mathrm{hr}$

$$
A \text { is the final sorbent surface area, } \mathrm{m}^{2} / \mathrm{g}
$$

The value of $A=$ was determined iteratively by first guessing a value for $A$ and then plotting $r$ (as calculated from Equation 12) versus $A-A=$. This process was repeated until a straight line was found. The final value for $A$ = which gave the best straight-line $f$ it on the NOXSO-4/4A data is 96 $\mathrm{m}^{2} / \mathrm{g}$; while the best $\mathrm{fit}$ value for NOXSO-2 is $152 \mathrm{~m}^{2} / \mathrm{g}$. The final plots of $\mathrm{r}$ versus $\mathrm{A}-\mathrm{A}=$ for NOXSO-2 and NOXSO-4/4A sorbents are shown in Figure 11.

The final equation showing the change of sorbent surface area with time in the LCTU is obtained by integrating Equation 11 with $r$ replaced by Equation 12.1. The results is shown as Equation 13. 


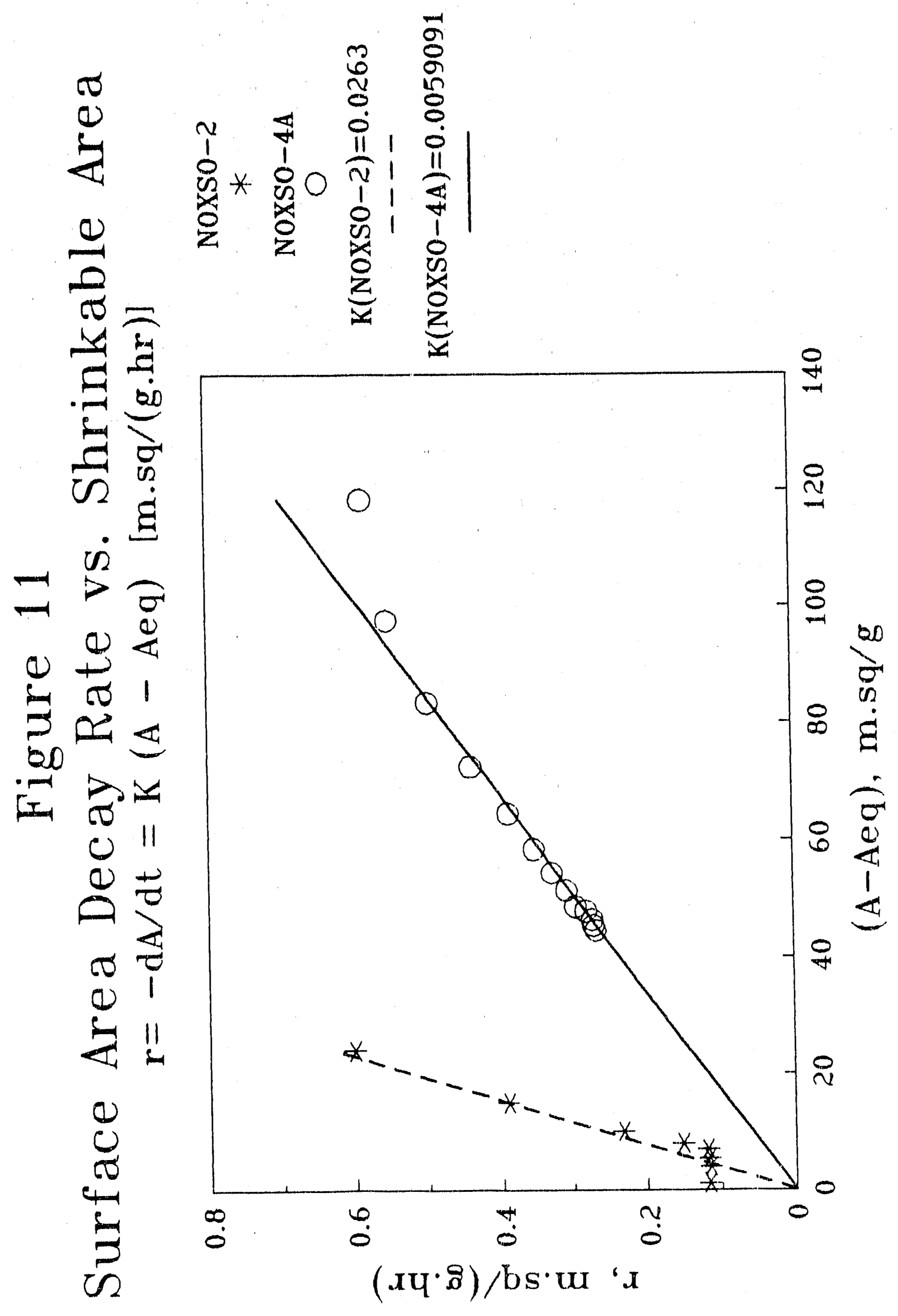




$$
A=\frac{A_{0}+K / a A}{1+K / a}+\left[A_{0}-\frac{A_{0}+K / a A_{0}}{1+K / a}\right] e^{-(a+K) t}
$$

Equation 13 and appropriate values for $a, K$, and $A=$ were uged to predict the surface area decay for NOXSO-2 and NOXSO-4A in the LCTU test. Figures 12 and 13 show the comparison of the measured surface area with those predicted by Equation 13 for NOXSO-2 and NOXSO-4A, respectively. The values of $a, K$, and $A_{=}$for NOXSO-2 and NOXSO-4A are listed in Table 15.

Table 15 also lists the final surface area, $A_{\infty}$, using different sorbents in various tests with their attrition loss. The value of $A_{\infty}$ is higher than $A_{=}$because $A_{\infty}$ takes into account the addition of makeup sorbent while $A$ does not. The fresh sorbent provides additional surface area. The value of $A_{\infty}$ is very close to the measured value as shown in Figures 12 and 13. Equation 13 was further used with the attrition rate employed in the Proof-of-Concept (POC) design to simulate the surface area decay during the POC test. The calculated rate of surface area decay in the POC is greater than the LCTU because of the difference in sorbent makeup rate. The results are also shown in Table 15 and Figure 13.

Table 15. Predicted Final Sorbent Surface Area in Different Tests

\begin{tabular}{llllllll} 
Sorbent & Test & A ${ }_{0}$ & \multicolumn{1}{c}{$\mathrm{a}$} & \multicolumn{1}{c}{$\mathrm{K}$} & \multicolumn{1}{c}{$\mathrm{A}$} & $\mathrm{A}_{\infty} *$ \\
NOXSO-2 & LCTU & 181 & 0.002211 & 0.02625 & 152 & 154.3 \\
NOXSO-4A & LCTU & 234 & 0.002722 & 0.00591 & 96 & 139.5 \\
NOXSO-4A & POC & 234 & 0.0003 & 0.00591 & 96 & 102.7
\end{tabular}

* A- is the surface area calculated from Equation 13 when $t$ approaches infinity. 


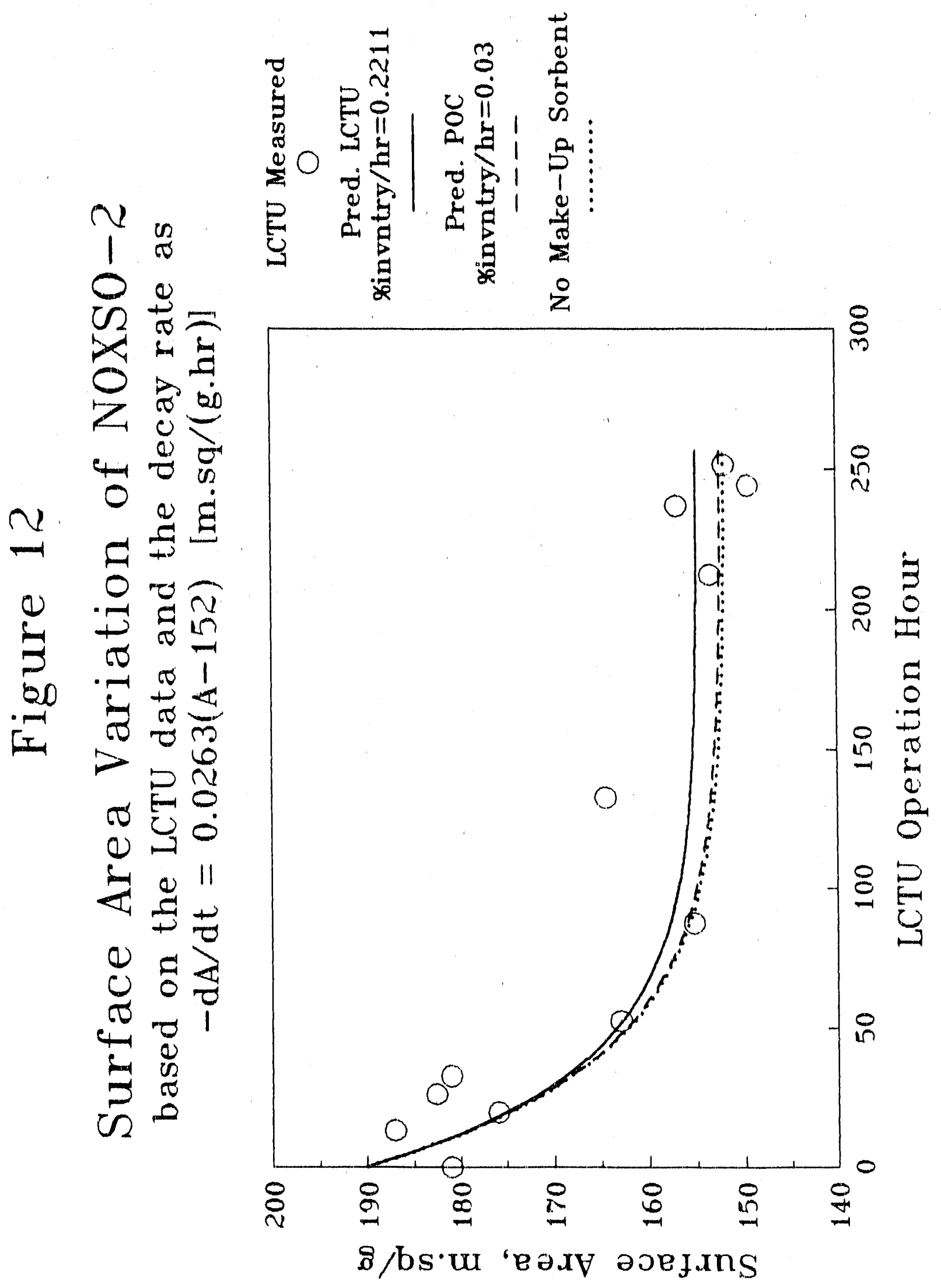




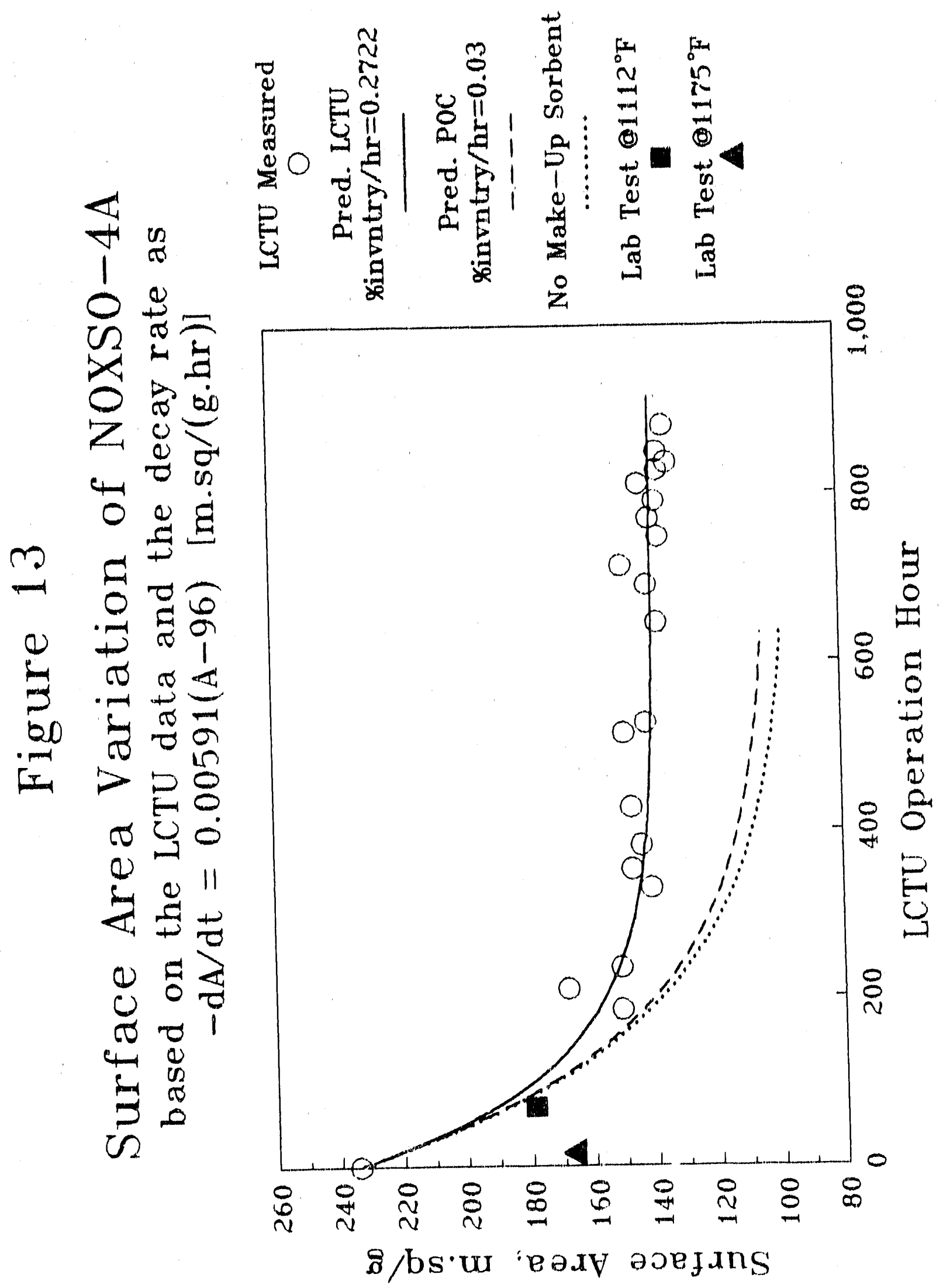


It has been mentioned in the Ifterature $[6,7]$ that the high temperature steam cauges the 108g of surface area of gamma-alumina, which to the support of Noxso sorbent. But the effect of sodium on the loss of surface area has not been studied. A bench-scale test was set up in the NOXSO laboratory to atudy the surface area decay rate for the NOXSO-4A. A $5 \mathrm{~g}$ fresh NOXSO-4A sample was placed in a $1 / 2 "$, flxed-bed reactor, Delonized water flowed through a $1 / 4^{\prime \prime}$ standard steel tube in an oven, which was controlled above $600^{\circ} \mathrm{C}$, to form high temperature steam. This steam then entered the fixed-bed reactor where a thermocouple was installed to monitor the sorbent temperature. The results are listed in Table 16.

\section{Table 16. NoxsO-4A Surface Area Change Through a High Temperature} steam Treatment in the Berich-scale Test

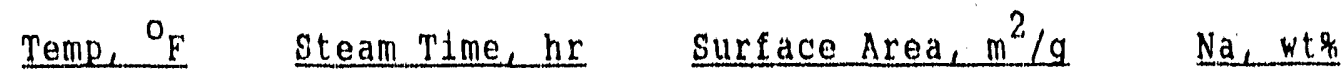

$\begin{array}{lccc}1175 & 15 & 166 & 3.41 \\ 1112 & 70.75 & 179 & 3.31 \\ \text { Fresh } & 0 & 234 & 4.0\end{array}$

Because the regeneration temperature of the LCTU was around $1117^{\circ} \mathrm{F}$, Equation 10 with the corresponding $K$ and $A=$ of NOXSO-4A is used to predict the surface area of the bench-scale test at $1112^{\circ} \mathrm{F}$, that is

$$
A=96+(234-96) \mathrm{e}^{-0.00591(70.75)}=186.8 \mathrm{~m}^{2} / \mathrm{g}
$$

which is only 4.48 error from the bench-scale test. It is important to mention that the result of the bench-scale test indicates that the surface area decay is a function of temperature. For instance, the 70-hour steaming conducted at low temperature as listed in Table 16 resulted in a higher 
surface area than the 15-hour steaming at high temperature. This implies that the higher $A_{=}$of NOXSO-2 compared to NOXSO-4A does not necesearlly mean NOXSO-2 1a auperior to NOXSO-4A in terms of gurface area decay, aince the regeneration temperatures for sorbents NOXSO-2 and NOXSO-4A were $1050^{\circ} \mathrm{F}$ and $1117^{\circ} \mathrm{F}$, raspectively.

The mechanism of the surface area decay was deduced from the mercury porosimeter results. Grace measured pore volumes of flve NOXSO-4A sorbent samplea each of alfferent age. The regults are tabulated in Table 17. Grace also conducted the gamma and alpha alumina analyges for NOXSO-4A after LCTU Test 14. The results show that the spent sorbent containg a very small amount of alpha alunina. The surface area decrease caused by the transition f rom gamma to alpha alumina should be rulod out. Since the residual sulfur content in the regenerated sorbent of the later LCTU tests, 1.e., Test 13 to Test 14, was usually lower than those in the earlier tests, 1.e., Tests 1 through 12, the surface araa decrease caused by pore-fouling with sulfur is not likely. However, the mercury porosimeter analysis shows that the average diameter of micropores in apent NOXSO-4A gorbent (after LCTU Test 14) is 135 angstroms, which is 1.4 times bigger than the fresh NOXSO-4A. The change in the average diameter of the micropores was very likely caused by the fusion of two nearby micropores to form a larger micropore. This sintering process reduces the sarbent surface area.

Various sorbent additives are avallable which are used to stabllize gurface area on industrial catalysts. NOXSO and Grace are currently testing Noxso sorbents treated with additives that have been used successfully in 
applications similar to the NOXSO process, 1.e., high temperature and stearn. The additives are typlcally used in concentrations less than one welght percent. Each new sorbent is being iested for activity $\left(\mathrm{SO}_{2} / \mathrm{NO}_{x}\right.$ removal efficlency), attrition strength, and surface area with hours of operation.

Table 17. Porosimetry Analygis of NOXSO-4A Sorbent [8]

Particle Average intc

Borbent Treatment

Fregh

Fresh

$650^{\circ} \mathrm{C} ; 175 \mathrm{hrg}$ air

Fresh $\quad 615^{\circ} \mathrm{C} ; 77$ hrs steam

Fresh $635^{\circ} \mathrm{C} ; 70$ hrg steam

Used
$E_{\text {niac }}^{\star} \underline{\text { Eimick }}^{\star \star}$

$0.03 \quad 0.67$

$0.06 \quad 0.69$

0.03

0.69

0.07

0.63

0.04

0.62
97

102

1.05

1.05

106

0.93

147

1.13

135
LCTU T'est 14D (sorbent cooler)

* E mac = sorbent internal voidage due to macropore

$\star \star E m i c=$ sorbent internal vaidage due to micropore

\section{$4.8 \mathrm{SO}_{2}$ and $\mathrm{NO}_{x}$ Removal Rinetics}

The tests conducted on the LCTU were mainly for the parametric study. The adsorber operation conditions were varied on purpose to investigate the $\mathrm{NO}_{x}$ and $\mathrm{SO}_{2}$ removal performance of NOxSO sorbent. In order to understand the impact of various parameters on the sorbent performance, a simplified mathematical model, which was derived in an earlier report [1], is 
generalized here for predicting $\mathrm{NO}_{x}$ and $\mathrm{SO}_{2}$ removal effictencies in the flutd-bed adsorber. The model has the following form:

$$
\ln \frac{y_{0}}{y_{i}}=\frac{-\rho \lambda N_{t}}{c_{0}} \frac{H}{v}\left[\frac{1}{y_{1} t+1 / k p}\right]
$$

Where $y_{0}$ is the outlet pollutant, $\mathrm{NO}_{x}$ or $\mathrm{sO}_{2}$, molar iraction

$y_{1}$ is the inlet pollutant molar fraction

$\rho$ is the sorbent dengity in a fluid-bed reactor, $\mathrm{g} / \mathrm{cm}^{3}$

$\mathrm{P}$ is the total gas presgure, atm

$K$ is the reaction rate constant, atm $\mathrm{sec}^{-1}$

$\mathrm{N}_{t}$ is the sodium molar content of sorbent, gmole $\mathrm{Na} / \mathrm{g}$ sorbent.

$\mathrm{C}_{0}$ io the molar gas concentration in the feed stream, gmole/ $\mathrm{cm}^{3}$

H is the flutdized bed height, $\mathrm{cm}$

$V$ is the superficial gas velocity, $\mathrm{cm} / \mathrm{sec}$

$t$ is the mean sorbent residence time in the adsorber, sec

$\lambda$ is the stoichiometric ratio of reactant gas to active sorbent material.

The values of $\lambda$ for $\mathrm{NO}_{x}$ and $\mathrm{SO}_{2}$ are obtained from a bench-scale, flxed-bed reactor [9]. They are:

$$
\begin{aligned}
& \text { For } \mathrm{NO}_{\mathrm{X}}: 1 / \lambda_{\mathrm{NOX}}=-4.789+0.075 \mathrm{~T} \\
& \text { For } \mathrm{SO}_{2}: 1 / \lambda_{\mathrm{SO} 2}=0.3761+0.00 \mathrm{~s} 2 \mathrm{~T}
\end{aligned}
$$

where $\mathrm{T}$ is the adsorber temperature, ${ }^{\circ} \mathrm{C}$. The product of $\lambda$ and $\mathrm{N}_{\mathrm{t}}$ is equal to the sorbent capacity, gmole pollutant/g sorbent. 
The $\mathrm{NO}_{\mathrm{X}}$ and $\mathrm{SO}_{2}$ removal efficiencies obtained from the $3 / 4 \mathrm{MW}$ tests [1] were used with Equation 15, 16, and 17 to calculate the reaction rate constant for each data point. The resultant rate constants were plotted against the adsorber temperature to show the temperature dependence. This is shown in Figures 14 and 15 for $\mathrm{NO}_{\mathrm{X}}$ and $\mathrm{SO}_{2}$, respectively. Since neither figure shows any temperature dependence, the rate constant data were averaged and the mean value was used to calculate the $\mathrm{NO}_{x}$ and $\mathrm{SO}_{2}$ removal efficiency in the LCTU.

$$
\begin{aligned}
& 1 / \mathrm{K}_{\mathrm{SO} 2}=0.763 \mathrm{~atm} \mathrm{sec} \\
& 1 / \mathrm{K}_{\text {NOX }}=0.5412 \mathrm{~atm} \mathrm{sec}
\end{aligned}
$$

It should be pointed out that the sorbent fluidization was different between the $3 / 4 \mathrm{MW}$ and the LCTU tests. The former used a 40-inch square fluid-bed with a bubble cap distributor, the latter used a 12-inch diameter fluid-bed with a J-tube distributor. The fluid bed at the LCTU showed significant slugging compared to the $3 / 4 \mathrm{MW}$ tests. The condition of the sorbent fluidization effects the value of $\rho$ and $H$ in Equation 15 . However, the product of $\rho$ and $H$ is equal to the product of the bulk sorbent density and the settled bed height. Therefore, for the first approximation, Equation 15 can be used without knowing the condition of fluidization. The consistency between data and the prediction in Equation 15, (shown at the end of this section) indicates that the rate of adsorption is not a strong function of gas/solid mixing. 


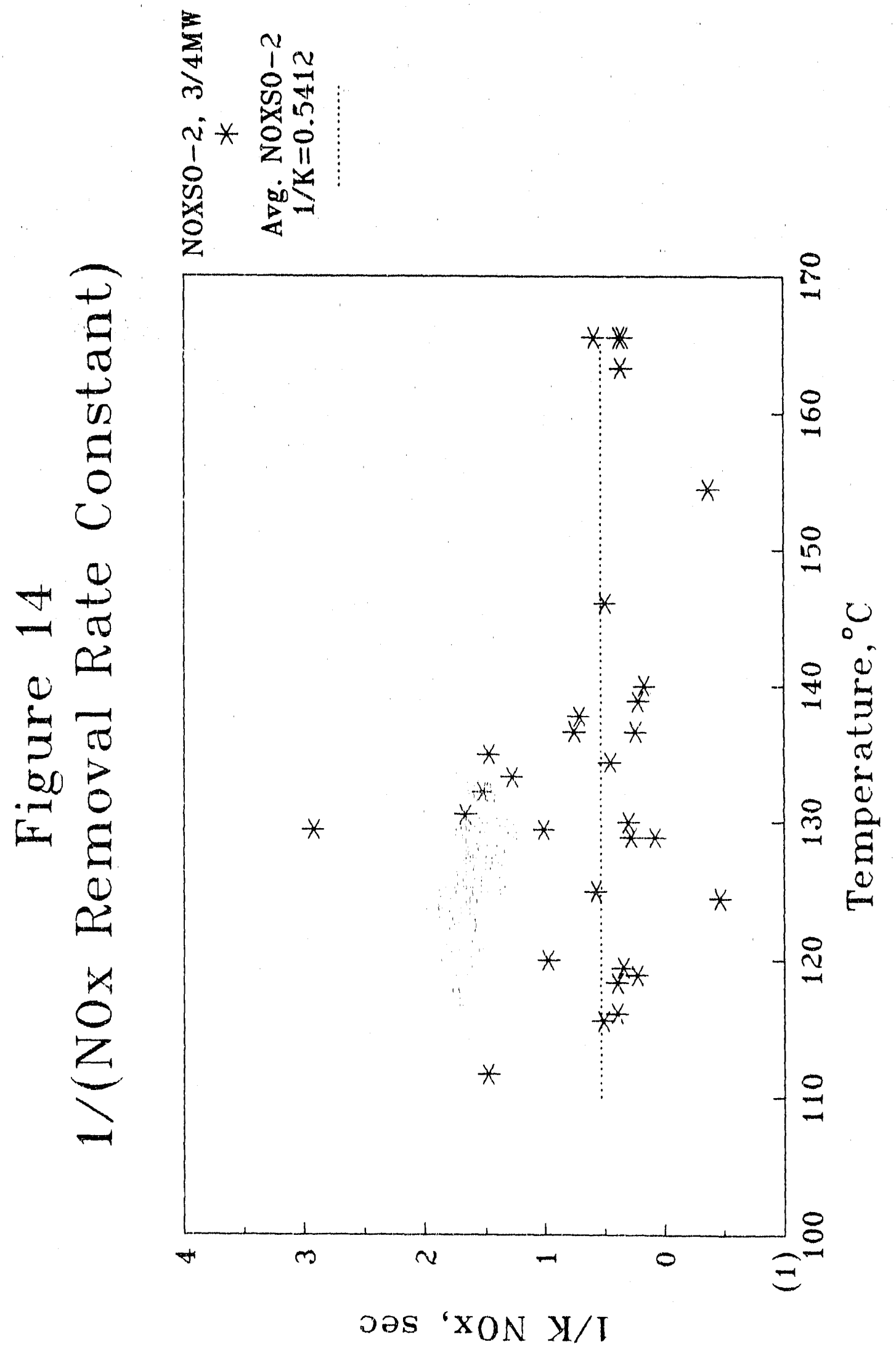




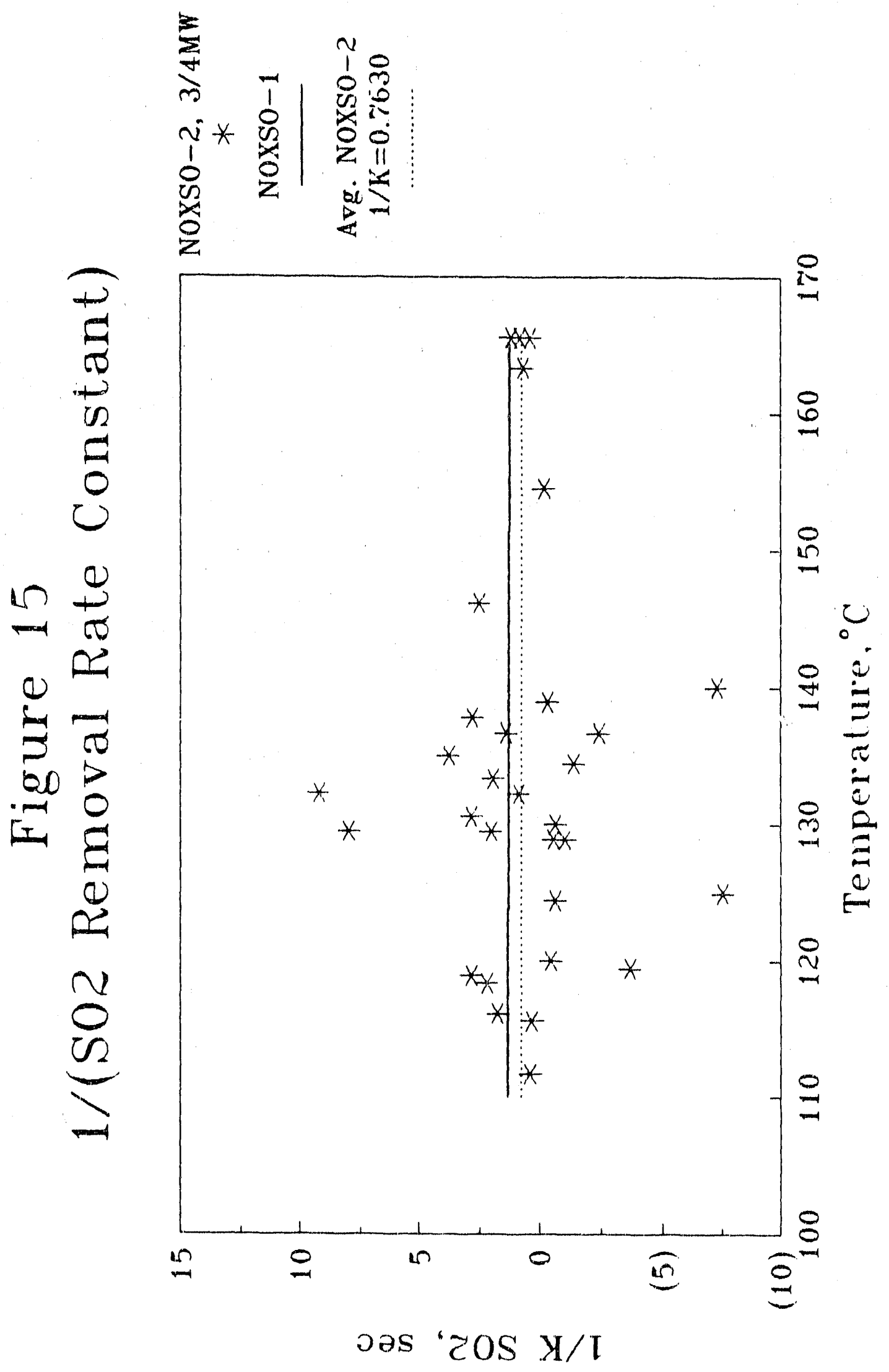


Equation 15 was modified to include attrition, surface area decay, sodium detrition, and residual sultur on the sorbent. This was done by correcting the $\mathrm{SO}_{2}$ capacity of the regenerated sorbent in Equation 15 by replacing $\lambda \mathrm{N}_{t}$ with:

$$
\left(\lambda N_{t}\right)_{\mathrm{SO}_{2}}=\left(\lambda_{\mathrm{SO}_{2}} \mathrm{~N}_{\mathrm{t}}+0.8 / 3200-\mathrm{s}_{\mathrm{reg}}{ }^{\prime 3200) *\left(\mathrm{~A} / \mathrm{A}_{\mathrm{O}}\right)}\right.
$$

where 0.8 is the averaged wt of the sulfur residue on the regenerated sorbent of the $3 / 4$ MW test

$S_{\text {reg }}$ is the wty of the sulfur residue on the regenerated
sorbent of the LCTU

3200 is the product of sulfur molecular weight and 100

A is the sorbent surface area, $\mathrm{m}^{2} / \mathrm{g}$

$A_{0}$ is the fresh sorbent surface area, $\mathrm{m}^{2} / \mathrm{g}$

The value of A was calculated from Equation 13 which contains the attrition and sorbent surface area decay effect.

Since the nitrogen content of he regenerated sorbent in the LCTU is less than 0.28 , we neglect the residual nitrogen and correct the ${ }^{\mathrm{NO}}{ }_{\mathrm{X}}$ capacity of the regenerated sorbent as follows:

$$
\left(\lambda \mathrm{N}_{t}\right)_{\mathrm{NO}}=\left(\lambda_{\mathrm{NO}} \mathrm{N}_{\mathrm{t}}\right) *\left(\mathrm{~A} / \mathrm{A}_{\mathrm{O}}\right)
$$

Equations $15,16,10$, and 21 were used with the operating conditions of the LCTU to calculate the $\mathrm{NO}_{x}$ removal efficiency. The calculated results are compared with the measured data in Figure 16. Equations 15, 17, 18, and 20 were used to calculate the $\mathrm{SO}_{2}$ removal efficiency for the LCTU. The 
measured $\mathrm{SO}_{2}$ removal efficiency is compared with the calculated results in Figure 17. Only the data points which show obvious differences between the measured and calculated value are labeled in Figures 16 and 17 . Both figures used the logarithmic scale to expand the data with less than 20 regeneration cycles such that the comparison would show clearly. The agreement between the calculated and measured data confirm the validation of Equation 15.

\subsection{Effect of Sulfur Loading on the NO ${ }_{x}$ Removal}

The $\mathrm{NO}_{\mathrm{x}}$ process chemistry [5] predicts that the adsorption of $\mathrm{SO}_{2}$ by sodium forms additional $\mathrm{NO}_{\mathrm{X}}$ adsorption sites to enhance the $\mathrm{NO}_{\mathrm{X}}$ removal capacity of the gamma alumina support. But these additionally adsorbed ${ }^{\mathrm{NO}} \mathrm{x}$ will desorb when the sorbent adsorbs more $\mathrm{SO}_{2}$. Therefore to achieve a maximum $\mathrm{NO}_{\mathrm{x}}$ removal efficiency, one ought to limit the sulfur loading on the sorbent diring the $\mathrm{SO}_{2}$ adsorption.

To find the relationship between sulfur loading on the sorbent and ${ }^{\mathrm{NO}} \mathrm{x}$ removal, we plot the amount of $\mathrm{NO}_{x}$ removed in the adsorber versus the molar ratio of sulfur to sodium content on the spent sorbent. The results and the data are shown in Figure 18 and Table 18, respectively. The amount of $\mathrm{NO}_{x}$ removed decreases when the $\mathrm{S} / \mathrm{Na}$ ratio increases. It is important to point out that the data of $\mathrm{S} / \mathrm{Na}$ ratio between 0.45 and 0.75 have the inlet ${ }^{\mathrm{NO}} \mathrm{x}$ concentration around $400 \mathrm{ppm}$. The data of $\mathrm{S} / \mathrm{Na}$ ratio below 0.45 have 600 ppm inlet $\mathrm{NO}_{x}$. Since hiri ${ }^{N O} \mathrm{x}_{\mathrm{x}}$ concentration results in a high reaction rate, the amount of ${ }^{N}{ }_{x}$ removed in the adsorber is higher for a high inlet 


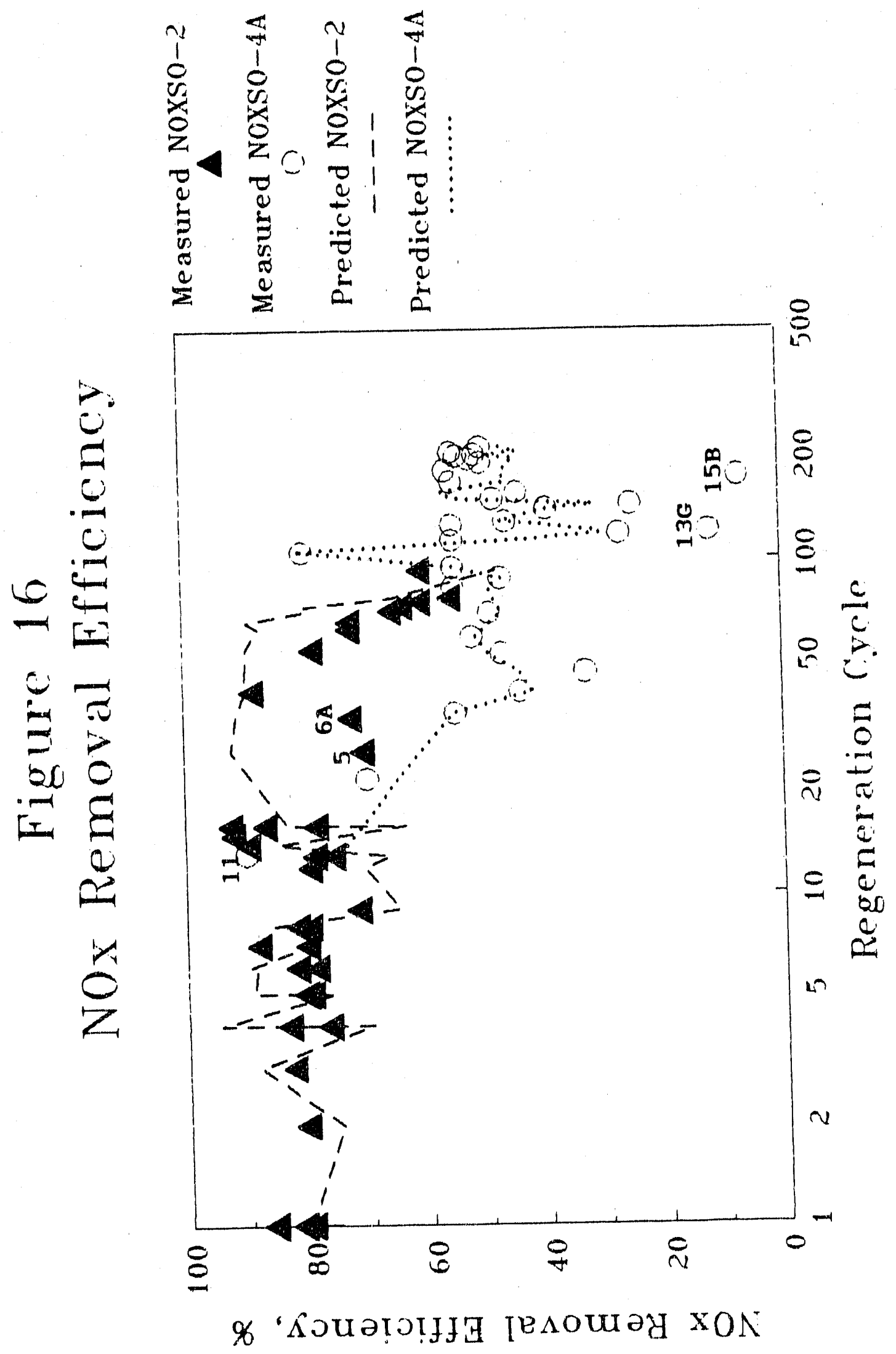




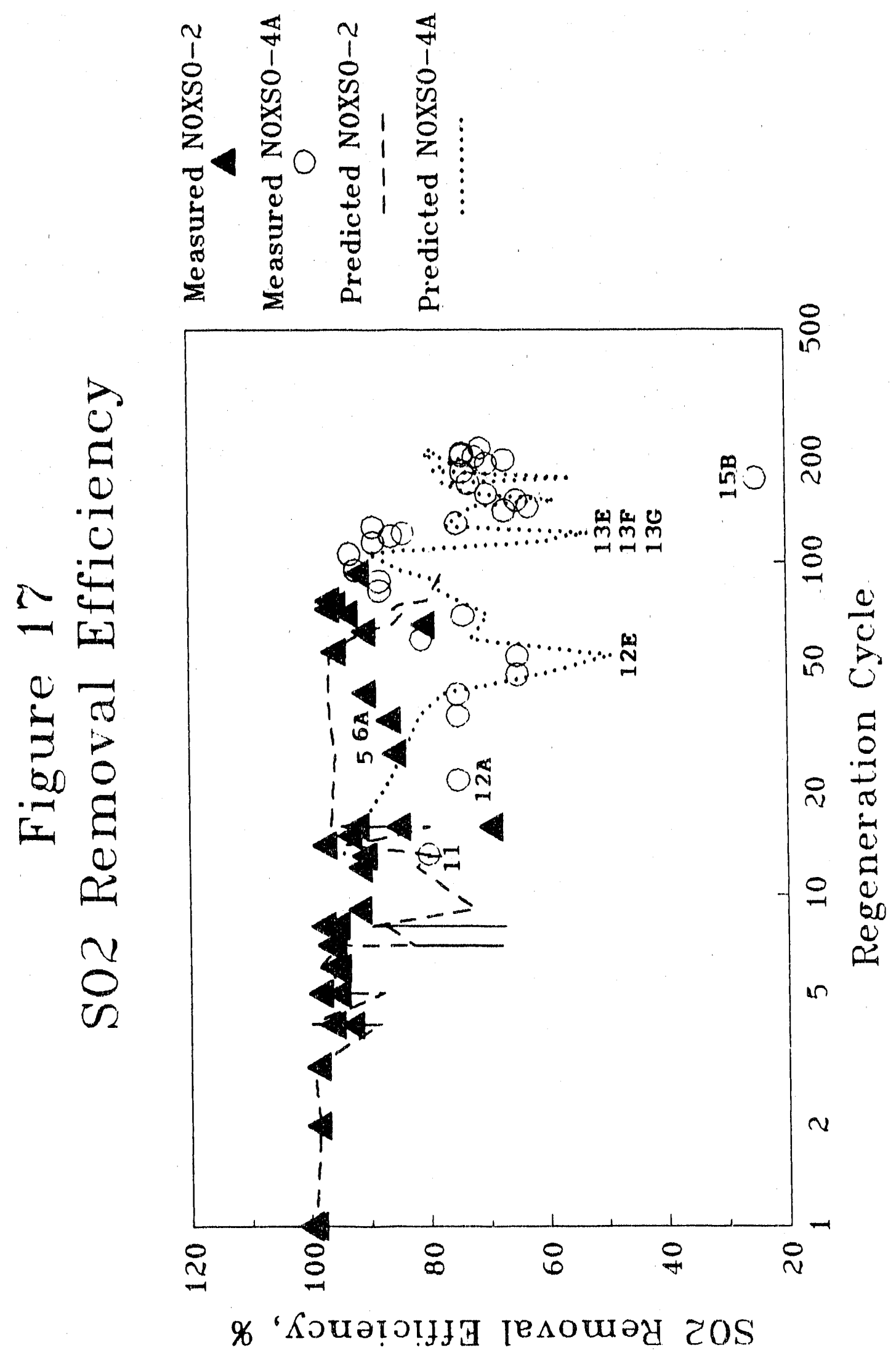




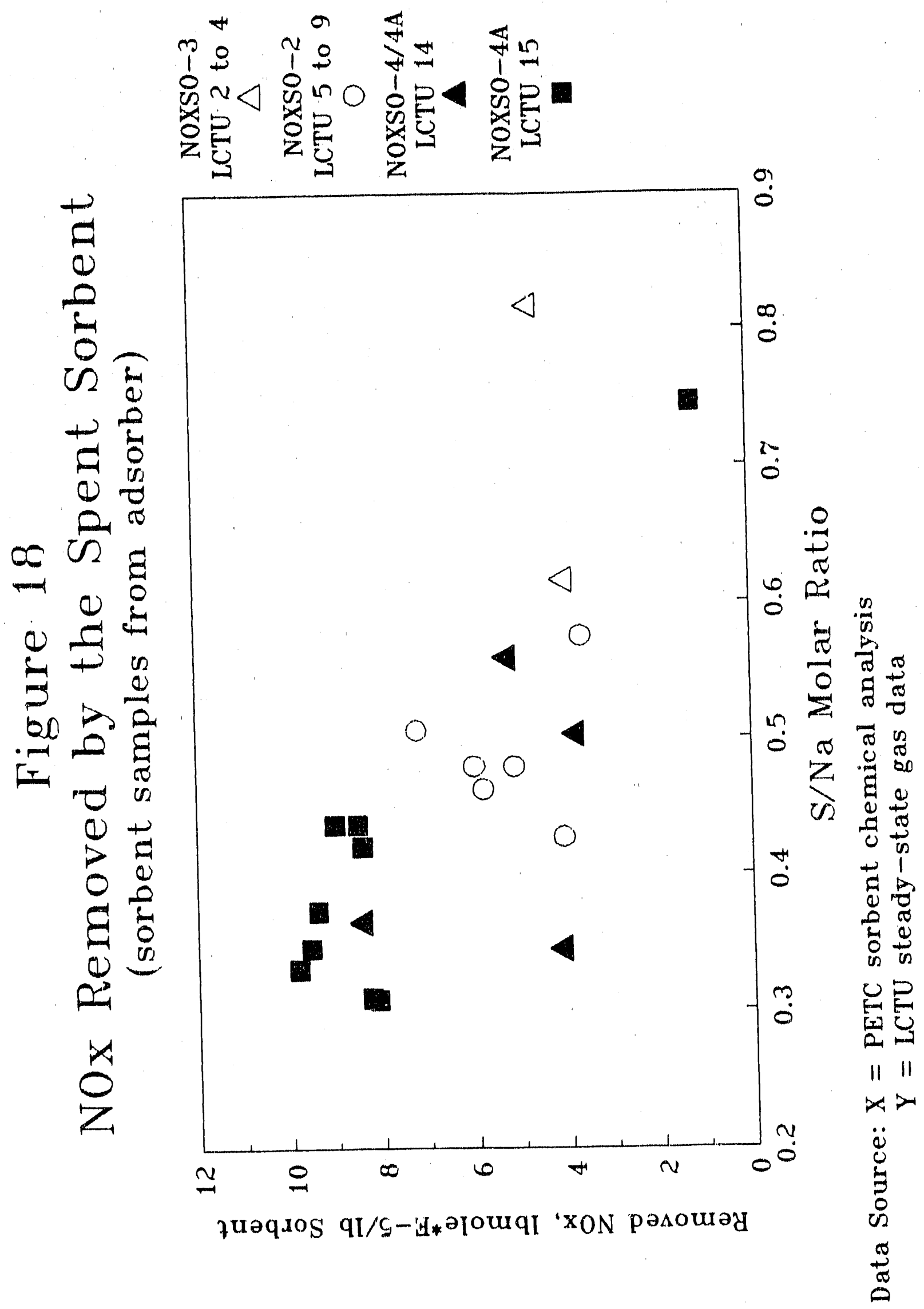


Table 18. NOx Removal and the sulfur Loading on the spent Sorbent

\begin{tabular}{|c|c|c|c|c|c|c|c|}
\hline $\begin{array}{l}\text { Test } \\
\text { No.\# }\end{array}$ & Sorbent & $\begin{array}{l}\text { Inlet } \\
\text { s02 Conc. } \\
\text { ppm }\end{array}$ & $\begin{array}{l}\mathrm{Na} \\
\mathrm{wtq}\end{array}$ & $\begin{array}{l}S \\
\text { wtq }\end{array}$ & $\begin{array}{l}\text { Ib mole NOx } \\
\text { Removed per } \\
\text { Ib Sorbent, } \times 10^{-5}\end{array}$ & $\begin{array}{c}\text { S/Na } \\
\text { Molar Rat io }\end{array}$ & $\underline{\operatorname{Kpn}} \times 10^{-5}$ \\
\hline $\begin{array}{l}2 \\
4\end{array}$ & $\begin{array}{l}3 \\
3\end{array}$ & $\begin{array}{l}1420 \\
1500\end{array}$ & $\begin{array}{l}2.2 \\
2.8\end{array}$ & $\begin{array}{l}2.5 \\
2.4\end{array}$ & $\begin{array}{l}4.658 \\
4.006\end{array}$ & $\begin{array}{l}0.817 \\
0.616\end{array}$ & $\begin{array}{l}4.954 \\
7.296\end{array}$ \\
\hline $\begin{array}{l}5 \\
6 \\
8 B \\
8 \mathrm{C} \\
8 \mathrm{D} \\
9\end{array}$ & $\begin{array}{l}2 \\
2 \\
2 \\
2 \\
2 \\
2\end{array}$ & $\begin{array}{l}1500 \\
1450 \\
1590 \\
1600 \\
1700 \\
1420\end{array}$ & $\begin{array}{l}3.0 \\
3.2 \\
2.7 \\
2.8 \\
2.7 \\
2.7\end{array}$ & $\begin{array}{l}2.4 \\
1.9 \\
1.8 \\
1.8 \\
1.8 \\
1.9\end{array}$ & $\begin{array}{l}3.685 \\
4.098 \\
5.138 \\
5.811 \\
6.000 \\
7.201\end{array}$ & $\begin{array}{l}0.575 \\
0.427 \\
0.479 \\
0.462 \\
0.479 \\
0.506\end{array}$ & $\begin{array}{l}6.466 \\
5.674 \\
3.978 \\
5.606 \\
5.290 \\
7.192\end{array}$ \\
\hline $\begin{array}{l}14 \mathrm{~A} \\
14 \mathrm{C} \\
14 \mathrm{D} \\
14 \mathrm{E}\end{array}$ & $\begin{array}{l}4 / 4 A \\
4 / 4 A \\
4 / 4 A \\
4 / 4 A\end{array}$ & $\begin{array}{l}1442 \\
1447 \\
2284 \\
1421\end{array}$ & $\begin{array}{l}2.7 \\
2.5 \\
2.3 \\
2.5\end{array}$ & $\begin{array}{l}1.37 \\
1.2 \\
1.79 \\
1.75\end{array}$ & $\begin{array}{l}8.398 \\
4.122 \\
5.238 \\
3.795\end{array}$ & $\begin{array}{l}0.365 \\
0.345 \\
0.559 \\
0.503\end{array}$ & $\begin{array}{l}5.889 \\
2.614 \\
6.019 \\
5.870\end{array}$ \\
\hline $\begin{array}{l}15 \mathrm{~A} 1 \\
15 \mathrm{~B} \\
15 \mathrm{~A} 2 \\
15 \mathrm{G} \\
15 \mathrm{~F} \\
15 \mathrm{D} \\
15 \mathrm{C} \\
1.5 \mathrm{E} \\
15 \mathrm{H}\end{array}$ & $\begin{array}{l}4 A \\
4 A \\
4 A \\
4 A \\
4 A \\
4 A \\
4 A \\
4 A \\
4 A\end{array}$ & $\begin{array}{l}1537 \\
1542 \\
1490 \\
1479 \\
1558 \\
1517 \\
1458 \\
1539 \\
1508\end{array}$ & $\begin{array}{l}2.7 \\
2.6 \\
2.7 \\
2.8 \\
2.8 \\
2.74 \\
2.8 \\
2.82 \\
2.79\end{array}$ & $\begin{array}{l}1.4 \\
2.7 \\
1.3 \\
1.7 \\
1.7 \\
1.6 \\
1.2 \\
1.3 \\
1.2\end{array}$ & $\begin{array}{l}9.387 \\
1.196 \\
9.554 \\
8.507 \\
9.000 \\
8.413 \\
8.094 \\
9.831 \\
8.239\end{array}$ & $\begin{array}{l}0.373 \\
0.746 \\
0.346 \\
0.436 \\
0.436 \\
0.420 \\
0.308 \\
0.331 \\
0.309\end{array}$ & $\begin{array}{l}7.499 \\
0.645 \\
7.193 \\
6.409 \\
6.626 \\
6.808 \\
5.315 \\
7.408 \\
5.665\end{array}$ \\
\hline
\end{tabular}

${ }^{N}{ }_{x}$ concentration. To reveal the effect of sulfur loading on the ${ }^{N O}{ }_{x}$ removal, one must consider the ${ }^{N} O_{x}$ concentration and the sorbent residence time.

Consider the fluid-bed adsorber as a mixed flow reactor, a balance on the $\mathrm{NO}_{\mathrm{X}}$ removal gives

$$
\frac{\Delta F_{N O}}{t_{S}}=K p \bar{y} \bar{n}
$$


Where $\Delta F_{N O}$ is the amount of ${ }^{N O}{ }_{x}$ removed, 1 bmole $N_{x} / 1$ b sorbent

${ }^{t} \mathrm{~s}$ is the sorbent resicence time in adsorber, sec

p Is the syatem pressure, atm

$\bar{y}$ is the log-mean $\mathrm{NO}_{\mathrm{x}}$ mole fraction

$K$ is the rate constant

$\vec{n}$ Is the average number of unoccupled No $x$ adsorption sites in the adsorber.

Rewriting Equation 22 gives

$$
\mathrm{kp} \bar{n}=\frac{\Delta F_{N O}}{t_{S} \bar{y}}=f(S / N a \text { molar ratio })
$$

Figure 19 shows the plot of $\mathrm{Kpn}$ versus $\mathrm{S} / \mathrm{Na}$ molar'ratio. The value of Kpin decreases when the $\mathrm{S} / \mathrm{Na}$ molar ratio is greater than 0.6 . Clearly, the sulfur loading on the sorbent ough to be controlled at iess than 0.6 to avold the sorbent losing $\mathrm{NO}_{x}$ removal ability.

Present data can not draw any conclusions about the effect of high $\mathrm{SO}_{2}$ inlet concentration on the $\mathrm{NO}_{x}$ removal. The inlet $\mathrm{SO}_{2}$ concentrations are listed in Table 18, in which the data were used to plot Figure 18. There is only one data point, Test $14 \mathrm{D}$, having a higher $\mathrm{SO}_{2}$ inlet concentration (2284 ppm versus 1400-1700 ppm) than other data points. However, the data of Test $14 \mathrm{D}$ does not show any difference in comparison with other data as shown in Figures 1.8 and 19. 


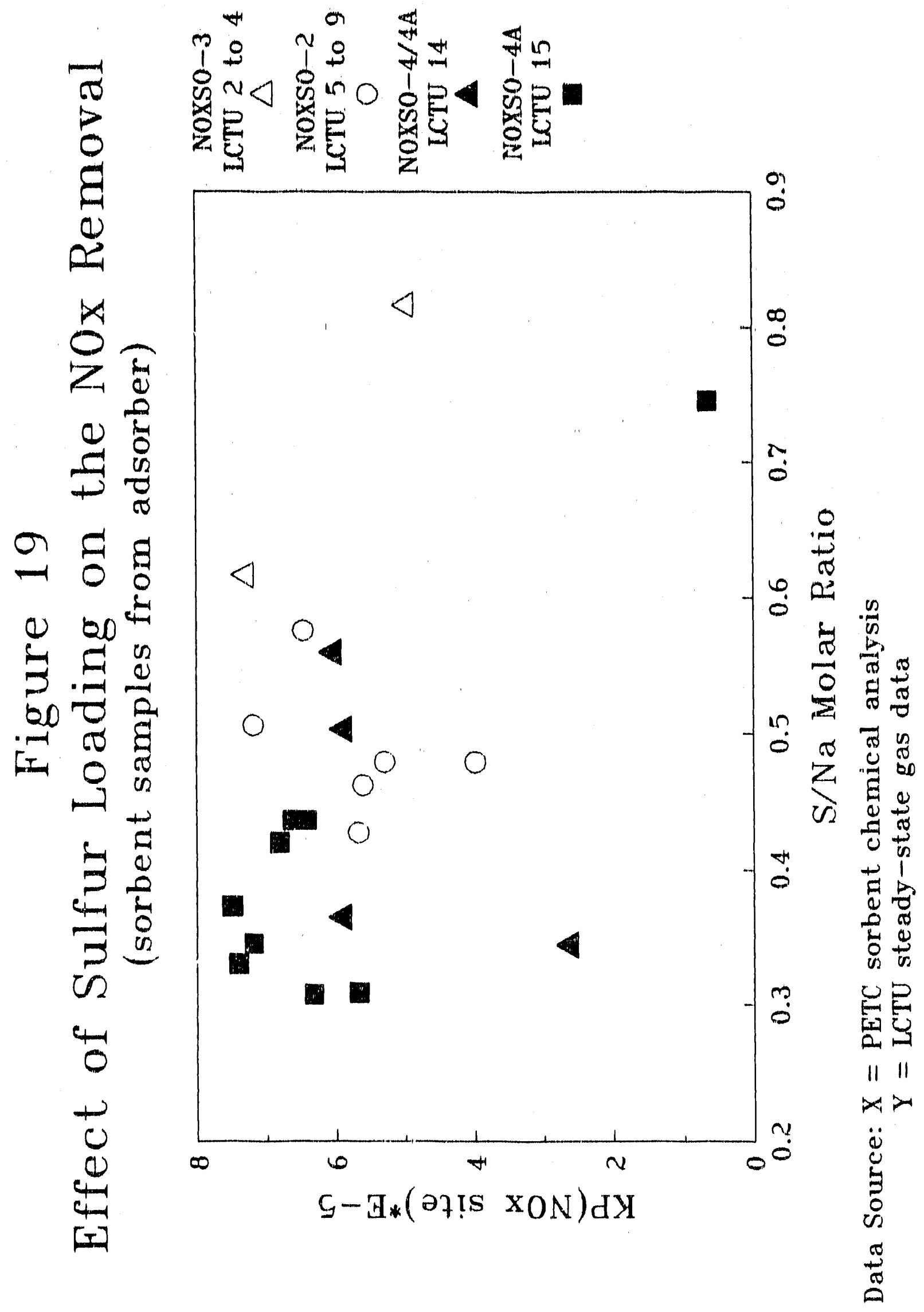


Tablo 19. Chemical Analysta (wt) of Spent Sorbent (PETC Moagurement).

\begin{tabular}{|c|c|c|c|c|c|c|c|c|c|c|c|c|c|}
\hline Test & Sorbent & $A 2$ & $\mathrm{Na}$ & $\$$ & c & $\|$ & $N^{\prime \prime}$ & $\mathrm{NO}_{2}^{-}$ & NO3 ${ }^{79}$ & $803^{7}$ & $804^{7}$ & $8=$ & $\cos =$ \\
\hline $\begin{array}{l}1 \text { ads } \\
2 \text { ads } \\
4 \text { ads }\end{array}$ & $\begin{array}{l}3 \\
3 \\
3\end{array}$ & $\begin{array}{l}30.3 \\
44.2\end{array}$ & $\begin{array}{l}2.7 \\
2.2 \\
2.8\end{array}$ & $\begin{array}{l}3.2 \\
2.5 \\
2.4\end{array}$ & & & $\begin{array}{l}<=0.05 \\
<=0.05\end{array}$ & $\begin{array}{r}0.03 \\
<=0.01\end{array}$ & $\begin{array}{l}0.23 \\
0.31\end{array}$ & $\begin{array}{l}<=0.01 \\
<=0.01\end{array}$ & $\begin{array}{l}5.99 \\
6.65\end{array}$ & & \\
\hline $\begin{array}{l}5 \text { ads } \\
6 \text { ads } \\
8 B \text { ads } \\
8 C \text { ads } \\
8 D \text { ads } \\
9 \text { ads }\end{array}$ & $\begin{array}{l}2 \\
2 \\
2 \\
2 \\
2 \\
2\end{array}$ & $\begin{array}{l}46.1 \\
46.4 \\
41.0 \\
41.3 \\
41.8 \\
45.9\end{array}$ & $\begin{array}{l}3.0 \\
3.2 \\
2.7 \\
2.8 \\
2.7 \\
2.7\end{array}$ & $\begin{array}{l}2.4 \\
1.9 \\
1.8 \\
1.8 \\
1.8 \\
1.9\end{array}$ & & & $\langle=0.05$ & $\begin{array}{c}\Leftrightarrow=0.01 \\
\Leftrightarrow=0.01 \\
0.011 \\
\Leftrightarrow=0.01 \\
0.01 \% \\
0.016\end{array}$ & $\begin{array}{l}0.32 \\
0.31 \\
0.48 \\
0.46 \\
0.41 \\
0.36\end{array}$ & $\begin{array}{l}\langle=0.01 \\
\langle=0.01 \\
\langle=0.01 \\
<=0.01 \\
\langle=0.01 \\
\langle=0.01\end{array}$ & $\begin{array}{l}7.98 \\
5.85 \\
5.94 \\
6.17 \\
5.75 \\
5.91\end{array}$ & $\begin{array}{l}0.0037 \\
0.0031 \\
0.0025\end{array}$ & \\
\hline $\begin{array}{l}11 \text { EOT ads } \\
12 \text { EOT ads }\end{array}$ & $\begin{array}{l}4 \\
4\end{array}$ & & $\begin{array}{l}3.0 \\
2.5\end{array}$ & $\begin{array}{l}2.6 \\
1.4\end{array}$ & & $\begin{array}{l}0.7 \\
0.4\end{array}$ & $\begin{array}{l}0.3 \\
0.2\end{array}$ & $\begin{array}{l}\iota=0.01 \\
\iota=0.01\end{array}$ & $\begin{array}{l}0.53 \\
0.39\end{array}$ & $\begin{array}{l}<=0.01 \\
\iota=0.01\end{array}$ & $\begin{array}{l}6.78 \\
3.62\end{array}$ & $\begin{array}{l}\Leftrightarrow=0.001 \\
\Leftrightarrow=0.001\end{array}$ & $\begin{array}{l}0.515 \\
0.32\end{array}$ \\
\hline 13EOT ads & $4 / 4 \mathrm{~A}$ & & 2.5 & 1.1 & $c=0.3$ & 3.1 & 0.2 & $<=0.01$ & 0.46 & $\iota=0.0 .1$ & 2.79 & $\langle\neq 0,001$ & 0.31 \\
\hline $\begin{array}{l}14 \mathrm{~A} \text { ads } \\
14 \mathrm{C} \text { ads } \\
1.4 \mathrm{~J} \text { ads } \\
14 \mathrm{E} \text { ads } \\
14 \mathrm{EO} \text { ' ads }\end{array}$ & $\begin{array}{l}4 / 4 A \\
4 / 4 A \\
4 / 4 A \\
4 / 4 A \\
4 / 4 A\end{array}$ & & $\begin{array}{l}2.7 \\
2.5 \\
2.3 \\
2.5 \\
2.7\end{array}$ & $\begin{array}{l}1.37 \\
1.2 \\
1.79 \\
1.75 \\
1.44\end{array}$ & $\begin{array}{l}<=0,3 \\
<=0,3 \\
<=0,3 \\
<=0,3 \\
<=0,3\end{array}$ & $\begin{array}{l}0.3 \\
0.08 \\
0.08 \\
0.05 \\
0.03\end{array}$ & $\begin{array}{l}0.1 \\
0.2 \\
0.2 \\
0.2 \\
0.2\end{array}$ & $\begin{array}{l}<=0.01 \\
<=0.01 \\
\langle=0.01 \\
\langle=0.01 \\
<=0.01\end{array}$ & $\begin{array}{r}0.43 \\
0.33 \\
<0.01 \\
0.32 \\
0.49\end{array}$ & $\begin{array}{l}<0.01 \\
10.01 \\
<0.01 \\
<0.01 \\
<0.01\end{array}$ & $\begin{array}{l}3.24 \\
2.32 \\
3.81 \\
3.73 \\
3.52\end{array}$ & $\begin{array}{l}\langle=0.001 \\
\Leftrightarrow=0.001 \\
\langle=0.001 \\
\Leftrightarrow=0.001 \\
\Leftrightarrow=0.001\end{array}$ & $\begin{array}{l}0.39 \\
0.56 \\
0.27 \\
0.37 \\
0.55\end{array}$ \\
\hline $\begin{array}{l}15 \mathrm{~A} 1 \text { ads } \\
15 \mathrm{~B} \text { ads } \\
15 \mathrm{~A} 2 \text { ads } \\
15 \mathrm{G} \text { ads } \\
15 \mathrm{~F} \text { ads } \\
15 \mathrm{D} \text { ads } \\
15 \mathrm{C} \text { ads } \\
15 \mathrm{E} \text { ads } \\
15 \mathrm{H} \text { ads }\end{array}$ & $\begin{array}{l}4 A \\
4 A \\
4 A \\
4 A \\
4 A \\
4 A \\
4 A \\
4 A \\
4 A\end{array}$ & & $\begin{array}{l}2.88 \\
2.62 \\
2.70 \\
2.78 \\
2.79 \\
2.74 \\
2.83 \\
2.82 \\
2.79\end{array}$ & $\begin{array}{l}1.4 \\
2.7 \\
1.3 \\
1.7 \\
1.7 \\
1.6 \\
1.2 \\
1.3 \\
1.2\end{array}$ & $\begin{array}{l}\langle=0.3 \\
\langle=0.3 \\
\langle=0.3 \\
<=0.3 \\
<=0.3 \\
<=0.3 \\
i=0.3 \\
<=0.3 \\
<=0.3\end{array}$ & $\begin{array}{l}0.6 \\
0.5 \\
0.5 \\
0.7 \\
0.7 \\
0.6 \\
0.5 \\
0.7 \\
0.7\end{array}$ & $\begin{array}{l}0.1 \\
0.1 \\
0.1 \\
0.3 \\
0.3 \\
0.1 \\
0.09 \\
0.2 \\
0.1\end{array}$ & $\begin{array}{c}0.13 \\
=0.01 \\
0.11 \\
\langle=0.01 \\
0.06 \\
0.04 \\
0.13 \\
0.097 \\
\langle=0.01\end{array}$ & $\begin{array}{l}0.38 \\
0.057 \\
0.34 \\
0.33 \\
0.31 \\
0.42 \\
0.37 \\
0.37 \\
0.35\end{array}$ & 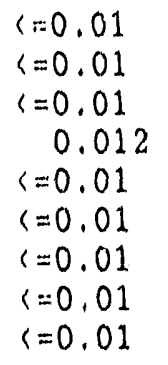 & $\begin{array}{l}2.47 \\
6.26 \\
2.65 \\
3.36 \\
2.81 \\
3.0 \\
2.53 \\
4.16 \\
2.07\end{array}$ & & $\begin{aligned}<= & =0.01 \\
\Leftrightarrow & =0.01 \\
& =0.01 \\
& =0.01 \\
& =0.01 \\
\Leftrightarrow & =0.01 \\
& 0.56 \\
& 0.45\end{aligned}$ \\
\hline
\end{tabular}

$\star \quad$ ads $=$ adsorber

$\star \star$ EOT $=$ End of Test

Table 20. Chemical Analysis (wt8) of NOx Regenerated Sorbent (PETC meagurement).

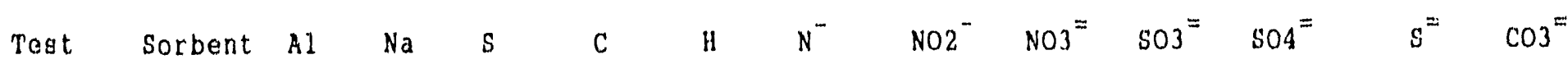
13EOT htr* 4/4A $\quad 2.4 \quad 1.2 \quad \Leftrightarrow=0.3 \quad \Leftrightarrow=0.03 \quad 0.1 \quad \Leftrightarrow=0.01 \quad \Leftrightarrow=0.01 \quad \Leftrightarrow=0.01 \quad 3.1 \quad \Leftrightarrow=0.001 \quad 0.271$ 14EOT htr* 4/4A $\quad 2.6 \quad 1.43 \quad \Leftrightarrow=0.3 \quad \Leftrightarrow=0.03 \quad 0.06 \quad \Leftrightarrow=0.01 \quad \Leftrightarrow=0.01 \quad \Leftrightarrow=0.01 \quad 3.34 \quad \Leftrightarrow=0.001 \quad 0.23$ * htr $=$ sorbent heater 
Table 21. Chemtcal Analygig (wt8) of Regenerated Borbent (PETC Measurement).

\begin{tabular}{|c|c|c|c|c|c|c|c|c|c|c|c|c|c|}
\hline Test & rbent & A) & $\mathrm{Na}$ & S & $\mathrm{C}$ & $\mathrm{H}$ & $\mathrm{N}^{-}$ & NO2" & $\mathrm{NO}^{\mathrm{I}}$ & $803^{=}$ & $\mathrm{SOS} 4^{7}$ & $\mathrm{~s}^{\prime \prime}$ & $\mathrm{CO}^{3}=$ \\
\hline $\begin{array}{ll}1 & \mathrm{cl} r \\
2 & \mathrm{clr} \\
4 & \mathrm{clr}\end{array}$ & $\begin{array}{l}3 \\
3 \\
3\end{array}$ & $\begin{array}{l}30.0 \\
44.0\end{array}$ & $\begin{array}{l}3.0 \\
2.2 \\
3.0\end{array}$ & $\begin{array}{l}2.6 \\
1.8 \\
1.7\end{array}$ & & & $\begin{array}{l}<0.03 \\
<0.05\end{array}$ & $\begin{array}{r}0.03 \\
<0.01\end{array}$ & $\begin{array}{l}(0.01 \\
10.01\end{array}$ & $\begin{array}{l}<0.01 \\
<0.01\end{array}$ & $\begin{array}{l}5.42 \\
5.00\end{array}$ & & \\
\hline $\begin{array}{l}5 \mathrm{clr} \\
6 \mathrm{clr} \\
8 \mathrm{~B} \mathrm{clr} \\
8 \mathrm{C} \mathrm{clr} \\
8 \mathrm{~d} \mathrm{clr} \\
9 \mathrm{dlr}\end{array}$ & $\begin{array}{l}2 \\
2 \\
2 \\
2 \\
2 \\
2\end{array}$ & $\begin{array}{l}47.5 \\
46.5 \\
42.6 \\
42.3 \\
44.8 \\
44.2\end{array}$ & $\begin{array}{l}3.1 \\
3.1 \\
2.9 \\
2.9 \\
2.8 \\
2.13\end{array}$ & $\begin{array}{l}1.6 \\
1.3 \\
0.6 \\
0.8 \\
0.7 \\
0.7\end{array}$ & & & $\begin{array}{l}<0.05 \\
10.05\end{array}$ & $\begin{array}{l}10.01 \\
<0.01 \\
<0.01 \\
10.01 \\
10.01 \\
10.01\end{array}$ & $\begin{array}{l}<0.01 \\
<0.01 \\
<0.01 \\
<0.01 \\
<0.01 \\
10.01\end{array}$ & $\begin{array}{l}<0.055 \\
<0.05 \\
0.17 \\
0.45 \\
0.14 \\
<0.01\end{array}$ & $\begin{array}{l}5.27 \\
4.32 \\
2.03 \\
2.29 \\
2.46 \\
1.95\end{array}$ & $\begin{array}{l}0.0020 \\
0.0036 \\
0.00096\end{array}$ & \\
\hline 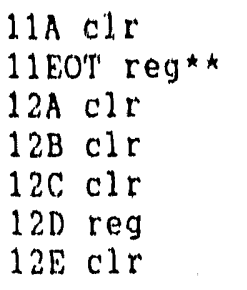 & $\begin{array}{l}4 \\
4 \\
4 \\
4 \\
4 \\
4 \\
4\end{array}$ & & $\begin{array}{l}3.2 \\
3.2 \\
3.0 \\
2.4 \\
2.5 \\
2.5 \\
2.7\end{array}$ & $\begin{array}{l}0.5 \\
0.2 \\
1.0 \\
1.3 \\
1.0 \\
0.9 \\
0.9\end{array}$ & $\begin{array}{l}<=0.3 \\
\langle=0.3 \\
\iota=0.3 \\
\iota=0.3 \\
\iota=0.3 \\
\iota=0.3 \\
\iota=0.3\end{array}$ & $\begin{array}{l}0.6 \\
0.6 \\
0.5 \\
0.6 \\
0.3 \\
0.3 \\
0.3\end{array}$ & $\begin{array}{l}0.1 \\
0.09 \\
0.09 \\
0.1 \\
0.2 \\
0.1 \\
0.2\end{array}$ & $\begin{array}{l}<=0.01 \\
\langle=0.01 \\
<=0.01 \\
<=0.01 \\
\langle=0.01 \\
i=0.01 \\
\langle=0.01\end{array}$ & $\begin{array}{c}0.063 \\
\Leftrightarrow=0.01 \\
0.039 \\
0.083 \\
\Leftrightarrow=0.01 \\
\Leftrightarrow=0.01 \\
0.096\end{array}$ & $\begin{array}{c}0.023 \\
0.04 \\
0.062 \\
<=0.01 \\
0.13 \\
0.19 \\
0.18\end{array}$ & $\begin{array}{l}1.05 \\
0.2 \\
2.33 \\
2.92 \\
1.99 \\
1.54 \\
2.29\end{array}$ & $\begin{array}{r}<0.001 \\
0.001 \\
0.006 \\
<0.001 \\
0.008 \\
<0.001 \\
0.009\end{array}$ & $\begin{array}{l}0.983 \\
0.873 \\
0.306 \\
0.506 \\
0.4 \\
0.432 \\
0.448\end{array}$ \\
\hline 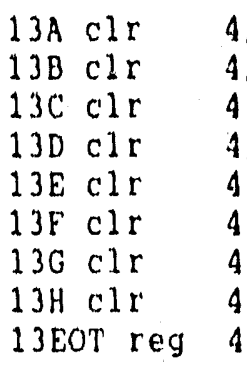 & $\begin{array}{l}4 / 4 A \\
4 / 4 A \\
4 / 4 A \\
4 / 4 A \\
4 / 4 A \\
4 / 4 A \\
4 / 4 A \\
4 / 4 A \\
4 / 4 A\end{array}$ & & $\begin{array}{l}2.5 \\
2.5 \\
2.5 \\
2.4 \\
2.5 \\
2.4 \\
2.5 \\
2.6 \\
2.7\end{array}$ & $\begin{array}{l}0.3 \\
0.6 \\
0.7 \\
0.3 \\
0.2 \\
0.2 \\
0.9 \\
0.3 \\
0.6\end{array}$ & 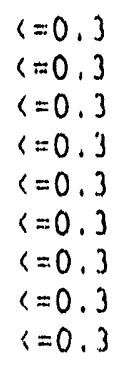 & $\begin{array}{l}0.5 \\
0.2 \\
0.3 \\
0.2 \\
0.2 \\
0.3 \\
0.1 \\
0.08 \\
10.03\end{array}$ & $\begin{array}{l}0.09 \\
0.1 \\
0.1 \\
0.1 \\
0.1 \\
0.09 \\
0.1 \\
0.1 \\
0.2\end{array}$ & $\begin{array}{l}<=0.01 \\
<=0.01 \\
<=0.01 \\
<=0.01 \\
<=0.01 \\
<=0.01 \\
<=0.01 \\
<=0.01 \\
<=0.01\end{array}$ & 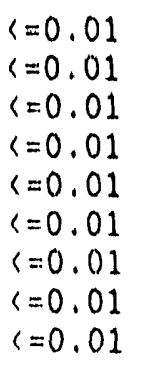 & $\begin{array}{l}0.065 \\
0.27 \\
0.12 \\
0.053 \\
0.014 \\
\iota=0.01 \\
<=0.01 \\
0.038 \\
0.082\end{array}$ & $\begin{array}{l}0.29 \\
0.91 \\
1.07 \\
0.63 \\
0.12 \\
0.23 \\
1.86 \\
0.48 \\
0.6\end{array}$ & $\begin{array}{l}0.011 \\
0.01 \\
0.006 \\
0.011 \\
0.017 \\
0.011 \\
0.001 \\
0.018 \\
0.023\end{array}$ & $\begin{array}{l}0.803 \\
0.445 \\
0.522 \\
0.511 \\
1.08 \\
1.196 \\
0.337 \\
0.598 \\
0.036\end{array}$ \\
\hline $\begin{array}{l}14 \mathrm{~A} \mathrm{Clr} \\
14 \mathrm{~B} \mathrm{clr} \\
14 \mathrm{C} \mathrm{clr} \\
14 \mathrm{D} \mathrm{clr} \\
14 \mathrm{E} \mathrm{clr} \\
14 \mathrm{EOT} \mathrm{Clr} \\
14 \mathrm{EOT} \mathrm{reg}\end{array}$ & $\begin{array}{l}4 / 4 A \\
4 / 4 A \\
4 / 4 A \\
4 / 4 A \\
4 / 4 A \\
4 / 4 A \\
4 / 4 A\end{array}$ & & $\begin{array}{l}2.7 \\
2.6 \\
2.5 \\
2.5 \\
2.4 \\
2.2 \\
2.7\end{array}$ & $\begin{array}{l}0.58 \\
0.60 \\
0.27 \\
0.64 \\
0.53 \\
0.65 \\
0.78\end{array}$ & $\begin{array}{l}<=0.3 \\
\langle=0.3 \\
<=0.3 \\
<=0.3 \\
<=0.3 \\
<=0.3 \\
<=0.3\end{array}$ & $\begin{array}{c}0.2 \\
<0.03 \\
0.04 \\
<0.03 \\
0.06 \\
0.2 \\
<0.03\end{array}$ & $\begin{array}{l}0.1 \\
0.1 \\
0.1 \\
0.1 \\
0.07 \\
0.06 \\
0.09\end{array}$ & $\begin{array}{l}<=0.01 \\
\langle=0.01 \\
<=0.01 \\
\langle=0.01 \\
\langle=0.01 \\
\langle=0.01 \\
\langle=0.01\end{array}$ & $\begin{array}{l}\quad 0.073 \\
\langle=0.01 \\
\iota=0.01 \\
\iota=0.01 \\
\iota=0.01 \\
\langle=0.01 \\
\iota=0.01\end{array}$ & $\begin{array}{c}0.056 \\
0.19 \\
0.043 \\
0.19 \\
\Leftrightarrow=0.01 \\
<=0.01 \\
0.15\end{array}$ & $\begin{array}{l}0.37 \\
0.28 \\
0.22 \\
0.41 \\
0.28 \\
0.52 \\
0.53\end{array}$ & $\begin{array}{l}<0.001 \\
0.02 \\
<0.001 \\
0.001 \\
<0.001 \\
<0.001 \\
10.001\end{array}$ & $\begin{array}{l}0.39 \\
1.56 \\
1.01 \\
0.8 \\
0.73 \\
0.2 \\
0.34\end{array}$ \\
\hline $\begin{array}{l}15 \mathrm{~A} 1 \mathrm{reg} \\
15 \mathrm{~B} \text { reg } \\
15 \mathrm{~A} 2 \mathrm{reg} \\
15 \mathrm{G} \text { reg } \\
15 \mathrm{~F} \text { reg } \\
15 \mathrm{deg} \\
15 \mathrm{Creg} \\
15 \mathrm{E} \text { reg } \\
15 \mathrm{H} \mathrm{reg}\end{array}$ & $\begin{array}{l}4 A \\
4 A \\
4 A \\
4 A \\
4 A \\
4 A \\
4 A \\
4 A \\
4 A\end{array}$ & & $\begin{array}{l}2.67 \\
2.57 \\
2.73 \\
3.02 \\
2.88 \\
2.69 \\
2.85 \\
3.04 \\
3.01\end{array}$ & $\begin{array}{l}0.4 \\
2.4 \\
0.4 \\
0.6 \\
0.8 \\
0.2 \\
0.4 \\
0.1 \\
0.2\end{array}$ & $\begin{array}{l}\langle=0.3 \\
\langle=0.3 \\
\langle=0.3 \\
\iota=0.3 \\
\iota=0.3 \\
\iota=0.3 \\
\iota=0.3 \\
\iota=0.3 \\
\iota=0.3\end{array}$ & $\begin{array}{l}0.4 \\
0.4 \\
0.4 \\
0.4 \\
0.4 \\
0.4 \\
0.4 \\
0.7 \\
0.5\end{array}$ & $\begin{array}{l}0.2 \\
0.1 \\
0.1 \\
0.1 \\
0.1 \\
0.1 \\
0.09 \\
0.1 \\
0.09\end{array}$ & $\begin{array}{l}<=0.01 \\
\langle=0.01 \\
\iota=0.01 \\
\iota=0.01 \\
\iota=0.01 \\
\iota=0.01 \\
\iota=0.01 \\
\iota=0.01 \\
\iota=0.01\end{array}$ & $\begin{array}{l}<=0.01 \\
<=0.01 \\
<=0.01 \\
\iota=0.01 \\
\iota=0.01 \\
\iota=0.01 \\
\iota=0.01 \\
\iota=0.01 \\
<=0.01\end{array}$ & $\begin{array}{c}\iota= \\
\Leftrightarrow=0.01 \\
0.01 \\
0.021 \\
0.34 \\
0.36 \\
0.015 \\
0.04 \\
0.031 \\
0.021\end{array}$ & $\begin{array}{l}0.76 \\
5.28 \\
0.64 \\
0.51 \\
0.88 \\
0.25 \\
0.95 \\
0.42 \\
0.44\end{array}$ & & $\begin{array}{l}0.04 \\
<0.01 \\
<0.01 \\
\\
<0.01 \\
<0.01 \\
<0.01 \\
0.36\end{array}$ \\
\hline
\end{tabular}




\subsection{Sorbent Chemical Analyais}

The PETC laboratories, using Lon chromatography and atomic adsorption techniques, conducted a detalled chentcal analysta for all the sorbents tested in the LCTU. Table 19 lists, the data of the spent sorbent from the adsorber. Table 20 is the data of the $\mathrm{NO}_{x}$-regenerated sorbent from the sorbent heater. Table 21 is the data of the sulfur-regenerated sorbent from efther the regenerator or the sorbent cooler. Before discugaing the data in Tables 19 through 21, one should be aware of the regeneration condition pertaining to each test. Hydrogen and steam were the regenerants for Tests 2 through 9. Natural gas and steam were the regenerants for Tests 1 and 11 through 15. The temperature for the hydrogen regeneration was $1060^{\circ} \mathrm{F}$, and for the natural gas was $1120^{\circ} \mathrm{F}$. The higher regeneration temperature left a lower sulfur content on the regenerated sorbent of Tests 11 through 15 than those of Tests 2 through 9.

Several interesting things are observed from tables 19 through 21. These observations support the Noxso process chemistry. They are listed below.

1. Most of the analytical results of the spent sorbent (Table 19) show undetectable amounts of nitrite, sulfite, and sulfide, but the amount of nitrate and sulfate is very significant. This indicates that the adsorption process in the adsorber is a highly oxidized reaction, and the removed $\mathrm{NO}_{x}$ and $\mathrm{SO}_{2}$ from the flue gas form mainly nitrate and sulfate. 
2. Although there are only two samples obtained from the sorbent heater (see Table 20), the undetectable amount of nitrite and nitrate shows that essenti:ly all of the adsorbed NO was removed in the sorbent heater.

3. The sulfite, sulfate, and sulfide species show up only on the sorbent obtained from the regenerator and sorbent cooler (see Table 21). This means that the sulfate formed in the adsorber was reduced not only to $\mathrm{SO}_{2}$ and $\mathrm{H}_{2} \mathrm{~S}$, but also to form sulfite and sulfide on the sorbent. Even with the air flow in the sorbent cooler, the sulfite did not form sulfate. This supports the NOXSO process chemistry which says that the presence of $\mathrm{NO}_{x}$ catalytically converts sulfite to sulfate.

$$
\mathrm{NaHSO}_{3(\mathrm{~s})}+1 / 2 \mathrm{O}_{2} \stackrel{\mathrm{NO}}{\longrightarrow} \mathrm{NaHSO}_{4}(\mathrm{~s})
$$

4. A sulfur balance between the solid analysis and the gas phase $\mathrm{SO}_{2}$ removal analysis was also conducted. The data and the results are tabulated in Table 22 . Only the tests which have the measured sulfur contents of both regenerated and spent sorbent were used in Table 22 . The sulfur removed from the flue gas was calculated according to the following equation.

Gas Phase $S, 1 b / \min =\frac{F_{G} \cdot 0.92}{379} \cdot \frac{[\mathrm{SO} 2] \cdot E}{10^{8}} \cdot 32$ 
Table 22. Gas/Solid Phase Sulfur Balance

\begin{tabular}{|c|c|c|c|c|c|c|c|c|c|}
\hline $\begin{array}{l}\text { Test } \\
\text { No. } 1\end{array}$ & $\begin{array}{c}\text { Measured } \\
\text { Sa } \\
\text { wt } \\
\end{array}$ & $\begin{array}{c}\text { Measured } \\
\mathrm{Sr} \\
w+8 \\
\end{array}$ & $\begin{array}{l}\text { Sorbent } \\
\text { Flowrate } \\
\text { lb/min }\end{array}$ & $\begin{array}{l}\text { Solid } \\
\text { Phase } \\
\text { lo/min }\end{array}$ & $\begin{array}{c}\text { Flue Gas } \\
\text { Flowrate } \\
\text { SCFM } \\
\end{array}$ & $\begin{array}{l}\mathrm{SO} 2 \\
\text { Conc. } \\
\text { ppm }\end{array}$ & $\begin{array}{c}\mathrm{SO} 2 \\
\text { Removal } \\
\quad \% \\
\end{array}$ & $\begin{array}{l}\text { Gas } \\
\text { Phase S } \\
\text { lb/min }\end{array}$ & $\begin{array}{l}\text { S thatio } \\
\text { ot solid } \\
\text { to Gas } \\
\end{array}$ \\
\hline 1 & 3.2 & 2.6 & 1 & 0.006 & 92 & 1450 & 35 & 0.003626 & 1.654 \\
\hline 2 & 2.5 & 1.8 & 1 & 0.007 & 101 & 1420 & 70 & 0.007798 & 0.898 \\
\hline 4 & 2.4 & 1.7 & 1.5 & 0.0105 & 104 & 1500 & 78 & 0.009451 & 1.111 \\
\hline 5 & 2.6 & 1.8 & 1.9 & 0.0152 & 103 & $15 n$ & 85 & 0.010201 & 1.490 \\
\hline $6 B$ & 2.1 & 1.4 & 1.9 & 0.0133 & 101 & 1600 & 90 & 0.011297 & 1.177 \\
\hline $7 \mathrm{~A}$ & 2.1 & 1.4 & 1.9 & 0.0133 & 105 & 1550 & 95 & 0.012010 & 1.107 \\
\hline $7 B$ & 2.3 & 1.3 & 1.9 & 0.019 & 110 & 2250 & 90 & 0.017302 & 1.098 \\
\hline $8 B$ & 2.1 & 0.8 & 1 & 0.013 & 105 & 1580 & 96 & 0.012371 & 1.051 \\
\hline $8 \mathrm{C}$ & 1.8 & 0.8 & 1 & 0.01 & 105 & 1600 & 95 & 0.012397 & 0.807 \\
\hline $8 D$ & 2.1 & 0.9 & 1 & 0.012 & 107 & 1700 & 96 & 0.013564 & 0.885 \\
\hline 9 & 1.8 & 0.7 & 1 & 0.011 & 103 & 1420 & 91 & 0.010338 & 1.064 \\
\hline 11 & 2.4 & 0.2 & 1 & 0.022 & 97 & 1500 & 80 & 0.009041 & 2.433 \\
\hline $13 \mathrm{~A}$ & 1.25 & 0.32 & 1 & 0.0093 & 113.2 & 1624 & 82.5 & 0.011781 & 0.789 \\
\hline $13 \mathrm{H}$ & 1.09 & 0.33 & 1 & 0.0076 & 116.5 & 1523 & 89 & 0.012266 & 0.620 \\
\hline $14 \mathrm{~A}$ & 1.29 & 0.56 & 1 & 0.0073 & 123.5 & 1442 & 75 & 0.010375 & 0.704 \\
\hline $14 \mathrm{~B}$ & 1.3 & 0.65 & 1 & 0.0065 & 116.5 & 1459 & 67 & 0.008846 & 0.735 \\
\hline $14 \mathrm{C}$ & 1.3 & 0.28 & 1 & 0.0102 & 116.5 & 1447 & 63 & 0.008249 & 1.236 \\
\hline $14 D$ & 1.7 & 0.74 & 1 & 0.0096 & 118 & 2284 & 65 & 0.013607 & 0.705 \\
\hline $14 \mathrm{E}$ & 1.61 & 0.66 & 1 & 0.0095 & 116.5 & 1421 & 70 & 0.009001 & 1.055 \\
\hline $15 \mathrm{~A} 1$ & 1.19 & 0.36 & 1 & 0.0083 & 116.5 & 1537 & 73 & 0.010153 & 0.817 \\
\hline $15 B$ & 2.61 & 2.4 & 1 & 0.0021 & 113.9 & 1542 & 25 & 0.003410 & 0.616 \\
\hline $15 \mathrm{~A} 2$ & 1.07 & 0.38 & 1 & 0.0069 & 114.1 & 1490 & 74 & 0.009772 & 0.706 \\
\hline $15 \mathrm{G}$ & 1.71 & 0.62 & 1 & 0.0109 & 117.6 & 1479 & 70 & 0.009457 & 1.153 \\
\hline $15 \mathrm{~F}$ & 1.42 & 0.72 & 1 & 0.007 & 113 & 1558 & 67 & 0.009162 & 0.764 \\
\hline $15 \mathrm{D}$ & 1.45 & 0.18 & 1 & 0.0127 & 112.4 & 1517 & 72 & 0.009536 & 1.332 \\
\hline $15 \mathrm{C}$ & 1.16 & 0.35 & 1 & 0.0081 & 113.5 & 1458 & 74 & 0.009512 & 0.852 \\
\hline $15 E$ & 1.25 & 0.13 & 1 & 0.0112 & 118 & 1539 & 74 & 0.010438 & 1.073 \\
\hline $15 \mathrm{H}$ & 1.02 & 0.18 & 1 & 0.0084 & 112.2 & 1508 & 71 & 0.009331 & $1 \quad 0.900$ \\
\hline & & & & & & & & $\begin{array}{l}\text { AVERAGE } \\
\text { MAXIMUM }\end{array}$ & $\begin{array}{l}E=1.030 \\
M=2.433\end{array}$ \\
\hline & & & & & & & & MINIMUM & $y=0.616$ \\
\hline
\end{tabular}


where $F_{G}$ is the flue gas flowrate, SCFM $60^{\circ} \mathrm{F}, 1$ atm

[s02] is the inlet $\mathrm{SO}_{2}$ concentration, ppm

$\mathrm{E}$ is the $\mathrm{SO}_{2}$ removal efficiency, *

32 is the molecular weight of sulfur, 1b/lbmole

0.92 is the dry gas volume fraction in the flue gas

379 is the mole gas volume at $60^{\circ} \mathrm{F}, 1 \mathrm{~atm}, \mathrm{ft}^{3} / 1 \mathrm{bmole}$

The sulfur gained on the sorbent was calculated by

Solid Phase $s, 1 b /$ min $=\left(s_{a}-s_{x}\right) * F_{S} / 100$

where $s_{a}$ is the sulfur content on the spent sorbent from adsorber, wt:

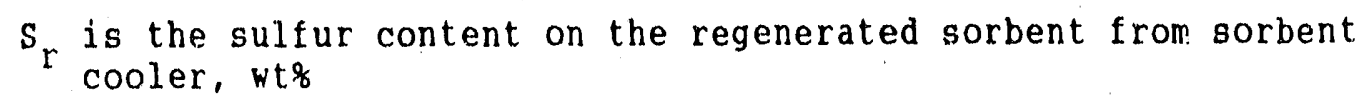
$F_{S}$ is the sorbent flowrate, $1 \mathrm{~b} / \mathrm{min}$

The plot of the amount of sulfur removed from the flue gas versus sulfur gained on the sorbent is shown in Figurr 20. Since only one (Test 11) out of 28 data points falls away from the equal line, the balance between the solid ung gas analyses is considered fairly good.

\subsection{CONCLUSION}

The LCTU operated for about 1500 hours. Three different sorbents were used through the tests. All the sorbents seem to possess a similar NO $\mathrm{x}$ removal ability. NOXSO-2 has a slightly better $\mathrm{SO}_{2}$ removal capability as compared to NOXSO-3 and NOXSO-4. NOXSO-3 has the worst attrition, while NOXSO-2 and NOXSO-4 show a similar attrition rate in the LCTU. But the LCTU 


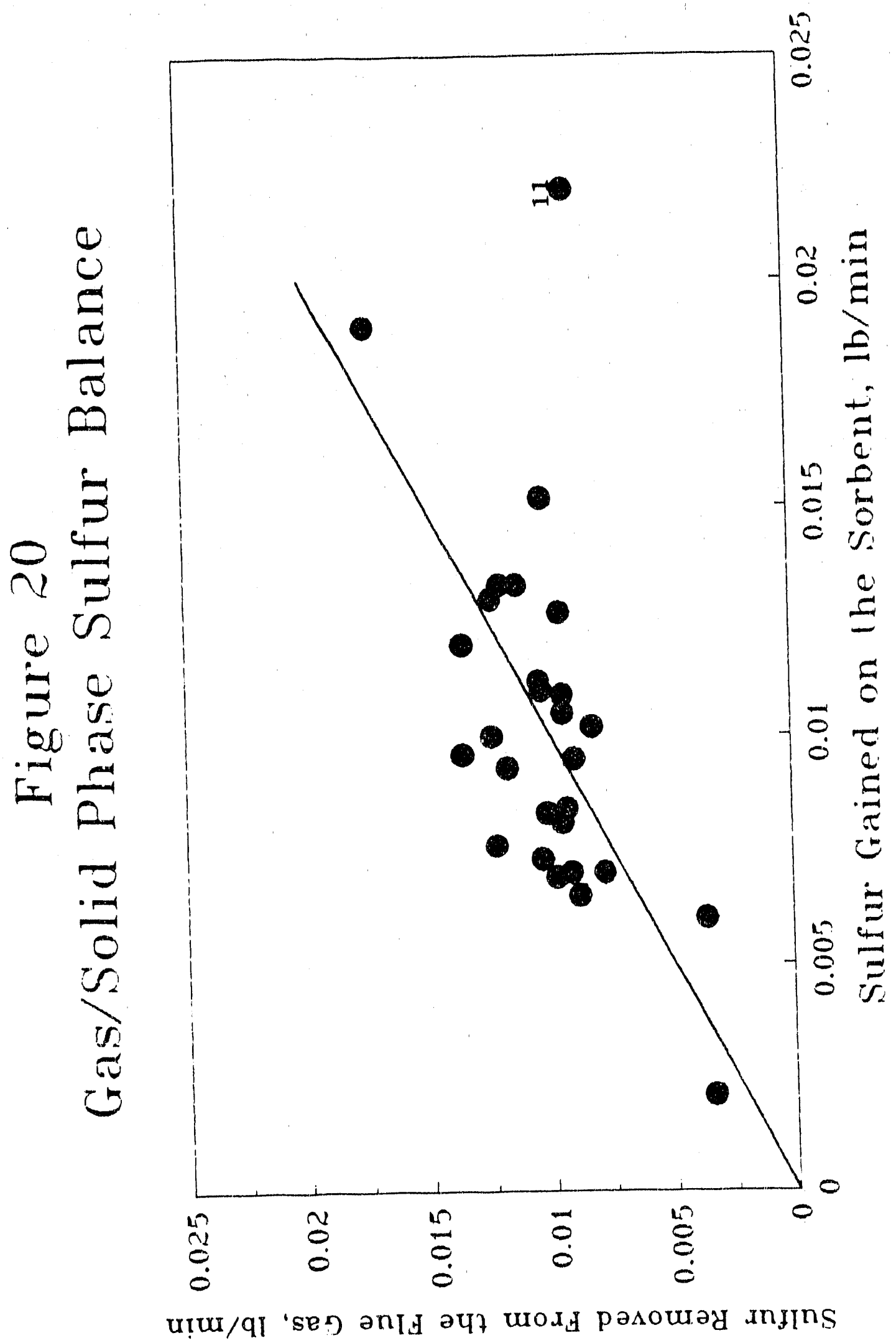


is a poor apparatus for determining relative rates of attrition, since most of the attrition in the LCTU is caused by the sorbent transport system and the unusually high gas velocities in the fluid bed heater and cooler.

The data obtained from the parametric study was used to develop an explicit design equation for $\mathrm{NO}_{x}$ and $\mathrm{SO}_{2}$ removal. The concept of using a single-vessel regenerator was proved feasible. Both natural gas and hydrogen successfully regenerated the spent sorbent. The regeneration kinetic study showed that the regeneration. is a first order reaction. The use of steam during regeneration helped to remove the residial sulfur, but the benefit of steam diminished when the inlet steam concentration exceeded 25\%. The residual sulfur affected the sorbent's $\mathrm{NO}_{x}$ removal ability. The parametric data showed that the ${ }^{N O} x$ removal started to fall when the sulfur/sodium molar ratio exceeded 0.6 . This puts a limit on the sorbent utilization for $\mathrm{SO}_{2}$ removal in the adsorber. The ${ }^{\mathrm{NO}} \mathrm{x}$ regeneration was completed by heating the sorbent up to the regeneration temperature. The amount of $\mathrm{SO}_{2}$ released during the heatup was about 68 o. the $\mathrm{SO}_{2}$ removed in the adsorber.

The results of the duration test showed that the ${ }^{N}{ }_{x}$ removal efficiency decreased rapidly in the first 30 cycles of regeneration. After that, the No $x$ removal efficiency stabilized. The decrease of NO$_{x}$ removal efficiency was due to the loss of sorbent surface area. The mercury porosimetry measurements indicate that the loss of surface area was caused by the fusion of two nearby micropores to form a larger pore. The $\mathrm{SO}_{2}$ removal efficiency also showed a slight decrease during the LCTU test. The loss of $\mathrm{SO}_{2}$ removal 
ability was attributed to the sodium detrition. The major loss of sodium content was also found in the first 10 cycles of regeneration. This sudden loss of sodium was caused by using the uncalcined sorbent.

Since the calcination $4+1)$ ncrase the sorbent cost, Noxso will continue to use uncalcined sorbent blat feed the fresh sorbent into the sorbent heater. The temperature of the sorbent heater is high enough to calcinate the fresh sorbent. NOxSO and W.R. Grace \& Co. are working together to curb the loss of sorbent surface area. Grace is seeking a stabilizer which will stabilize the sorbent surface area after a few regeneration cycles. The preferred stabilizer will be the rare earth metal which exists in the flyash. To use the component of flyash will eliminate the concern of environmental impact caused by the attrited sorbent. NOXSO is looking for an alternate regenerant which will react at lower temperatures. The lower regeneration temperatures are expected to slow the sorbent sintering process. The preferred candidates are popularly used reducing gases.

\subsection{PRESENTATIONS FROM THE WORK OF THE LIFE CYCLE TEST}

The results of the Life Cycle Test of the Noxso process were presented in the following meetings.

1. Haslbeck, J.L.; Yeh, J.T.; Ma, W.T.; Solar, J.P.; Pennline, H.W. Life Cycle Test of the NOXSO Process: Simultaneous Removal of NOX and SO2. From Flue Gas. Presented at the 1989 AWMA Annual Meeting, June 1989, Anaheim, California. 
2. Yeh, J.T.; Ma, W.T.; Pennline, H.W.; Haslbeck, J.L.; Gromicko, F.N. Integrated Testing of the Noxso Process: Simultaneous Removal of $\mathrm{SO2}$ and NOx From Flue Gas. Presented at the AIChE Spring National Meeting, March 1990, Orlando, Florida.

3. Ma, W.T.; Yeh, J.T.; Haslbeck, J.L.; Neal, L.G. The Life Cycle Test of the NOXSO $502 /$ NOx Flue Gas Treatment Process. To be presented at the AIChE Summer National Meeting, August 1990, San Diego, California.

\subsection{REFERENCES}

1. Haslbeck, J.L.; Ma, W.T.; Neal, L.G. A Pilot Scale Test of the NOXSO Flue Gas Treatment Process. June 1988. NOXSO Corporation Cooperative Agreement Report submitted to U.S. DOE. Report No. DE-FC22-85PC81503.

2. Bisio, Attilio; Kabel, R.L. Scaleup of Chemical Process. 1985. John Wiley \& Sons. p. 397.

3. Haslbeck, J.L.; Yeh, J.T.; Ma, W.T.; Solar, J.P.; Pennline, H.W. Life Cycle Test of the NOXSO Process: Simultaneous Removal of NOx and SO2 From Flue Gas. Presented at the 1989 AWMA Annual Meeting, June 1989, Anaheim, California.

4. Yeh, J.T.; Drummond, C.J.; Haslbeck, J.L.; Neal, L.G. The NoxsO Process: Simultaneous Removal of $\mathrm{SO} 2$ and NOx From Flue Gas. Presented at the 1987 Spring National AIChE Meeting, March 29 - April 2, 1987, Houston, Texas.

5. Haslbeck, J.L.; Neal, L.G.; Peng, C.P.; Wang, C.J. Evaluation of the NOXSO Combined NOx/SO2 Flue Gas Treatment Process. April 1985. NOXSO Corporation Contract Report submitted to U.S. DOE. Report No. DOE/PC $73225-\mathrm{T} 2$.

6. Pearson, M.J. Recent Development in Claus Catalysts. November 24, 1972. Presented at the Canadian Natural Gas Processors' Association. Calgary, Canada.

7. Pop, G.; etal. Coke Deposits Formation and Products Selectivities for the MTG Process in a Fluidized Bed Reactor. Chemical Engineering Science. Vol. 44, No.1, p. 49. 1989.

8. Hager, M. NOXSO Process Development. 3rd Quarter Review Meeting, 1989.

9. Haslbeck, J.L.; Ma, W.T.; Neal, L.G. NOXSO Process Development: Progress Report 6. September 21, 1988. 

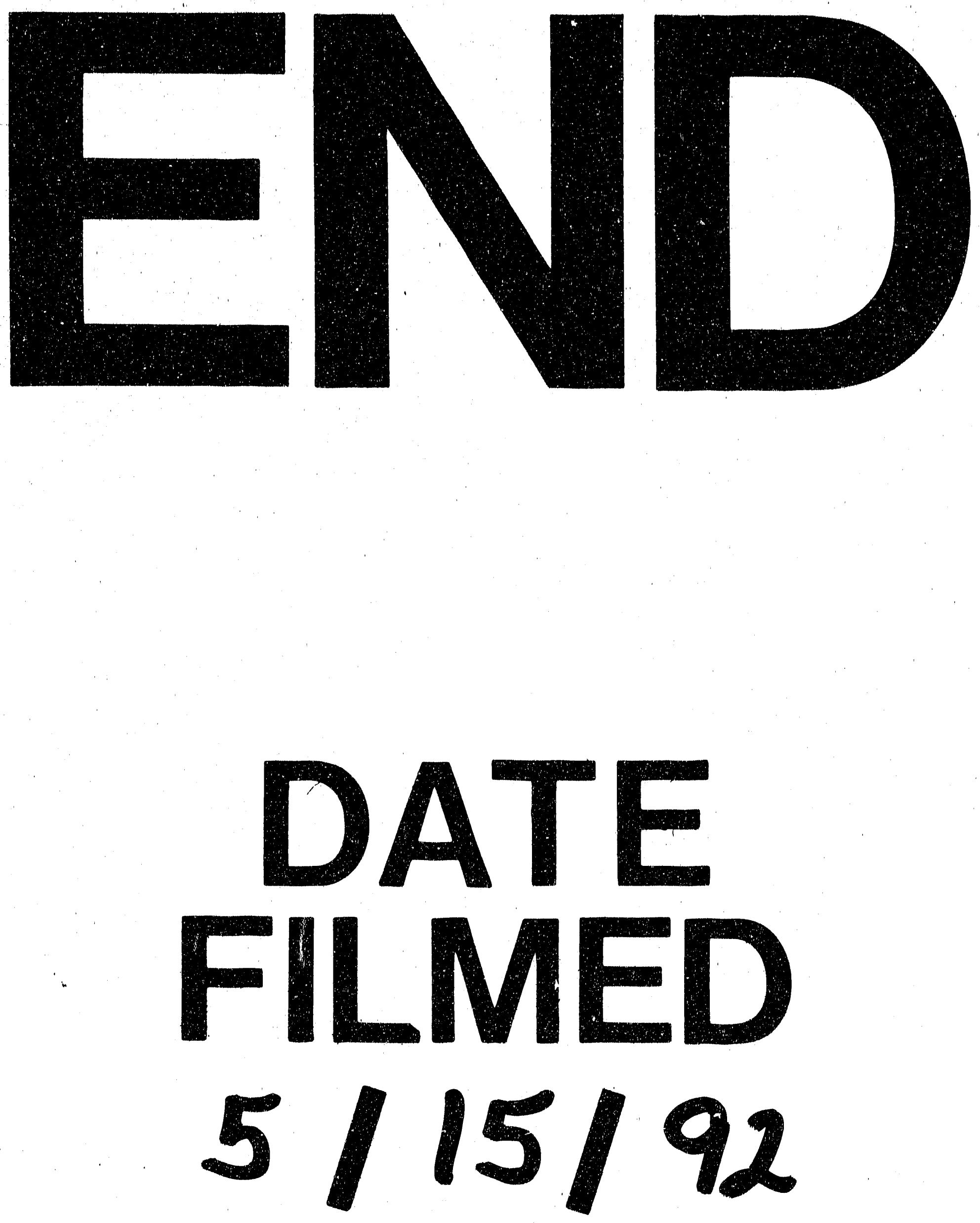

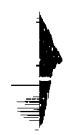

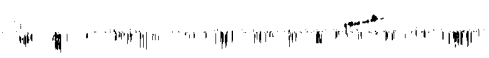


